Prepared in cooperation with the Kansas Department of Health and Environment

\title{
Spatial and Temporal Variability of Harmful Algal Blooms in Milford Lake, Kansas, May through November 2016
}

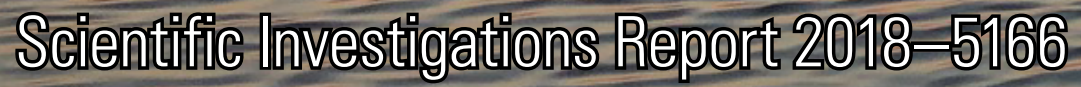




\section{Cover photographs:}

Front cover: Sunrise over Milford Lake, Kansas. Photograph taken by L.R. King.

\section{Rear cover:}

Harmful algal bloom in Zone C, north of the causeway, Milford Lake, Kansas. Photograph taken by L.R. King.

U.S. Geological Survey hydrologist conducting field work on

Milford Lake, Kansas.

Photograph taken by J.L. Graham.

Harmful algal bloom in Zone $C$, south of the causeway, Milford Lake, Kansas. Photograph taken by L.R. King.
Harmful algal bloom in Zone $\mathrm{C}$ of Milford Lake, Kansas.

Photograph taken by J.L. Graham.

Discrete sample taken in Zone $C$, south of the causeway, on July 21, 2016

Photograph taken by A.R. Kramer.

Harmful algal bloom in Zone $\mathrm{C}$ of Milford Lake, Kansas.

Photograph taken by J.L. Graham.

Kansas Department of Health and Environment and U.S. Army Corps of Engineers Harmful Algal Bloom Information signage, Milford Lake, Kansas. Photograph taken by J.L. Graham.

Harmful algal bloom in Zone C, north of the causeway, Milford Lake, Kansas. Photograph taken by L.R. King.
Harmful algal bloom in the wake of the research vessel, Milford Lake, Kansas. Photograph taken by J.L. Graham. 


\section{Spatial and Temporal Variability of Harmful Algal Blooms in Milford Lake, Kansas, May through November 2016}

By Guy M. Foster, Jennifer L. Graham, and Lindsey R. King

Prepared in cooperation with the Kansas Department of Health and Environment

Scientific Investigations Report 2018-5166 


\title{
U.S. Department of the Interior \\ DAVID BERNHARDT, Acting Secretary
}

\author{
U.S. Geological Survey \\ James F. Reilly II, Director
}

U.S. Geological Survey, Reston, Virginia: 2019

For more information on the USGS - the Federal source for science about the Earth, its natural and living resources, natural hazards, and the environment-visit https://www.usgs.gov or call 1-888-ASK-USGS.

For an overview of USGS information products, including maps, imagery, and publications,

visit https://store.usgs.gov.

Any use of trade, firm, or product names is for descriptive purposes only and does not imply endorsement by the U.S. Government.

Although this information product, for the most part, is in the public domain, it also may contain copyrighted materials as noted in the text. Permission to reproduce copyrighted items must be secured from the copyright owner.

Suggested citation:

Foster, G.M., Graham, J.L., and King, L.R., 2019, Spatial and temporal variability of harmful algal blooms in Milford Lake, Kansas, May through November 2016: U.S. Geological Survey Scientific Investigations Report 2018-5166, 36 p., https://doi.org/10.3133/sir20185166. 


\section{Contents}

Abstract

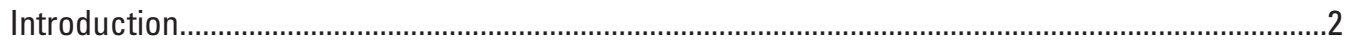

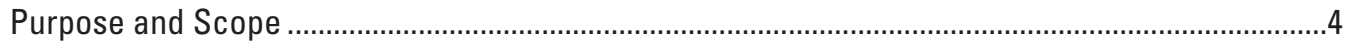

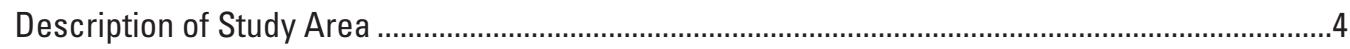

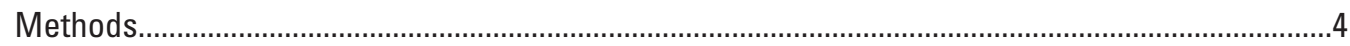

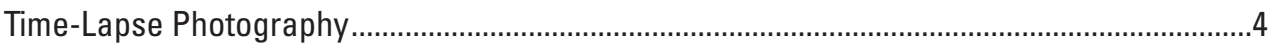

Continuous Water-Quality Site-Milford Lake near Wakefield, Kansas...................................

Discrete Sample Collection and Analysis..............................................................................

Spatial Data Collection .........................................................................................................

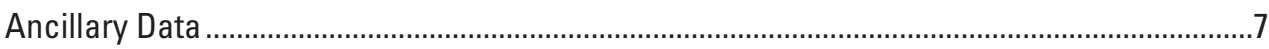

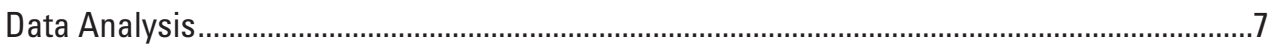

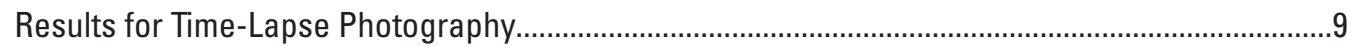

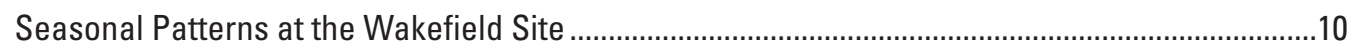

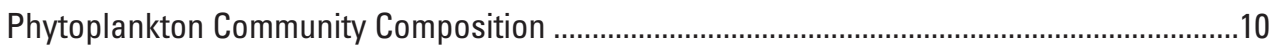

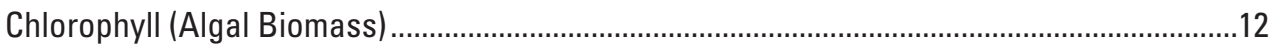

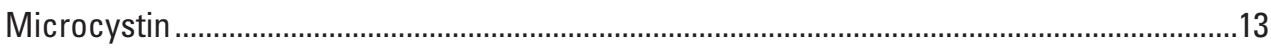

Spatial and Temporal Variability ...........................................................................................

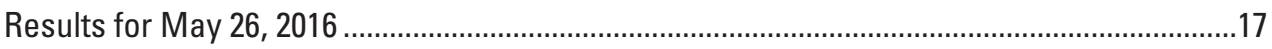

Discrete Sample Results ...........................................................................................17

Spatial Survey Results ..............................................................................................

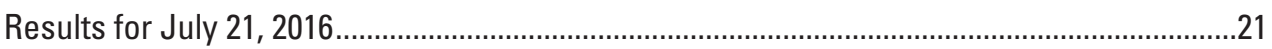

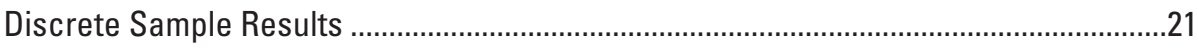

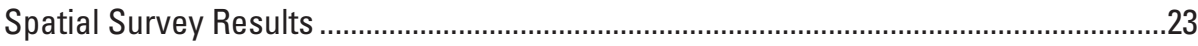

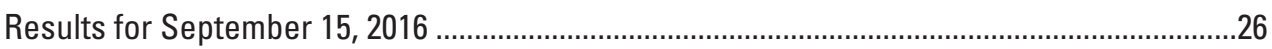

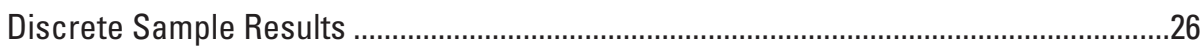

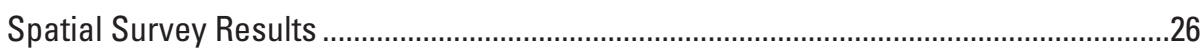

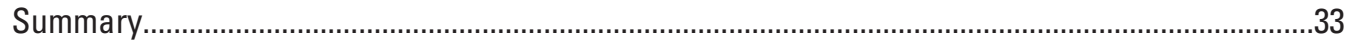

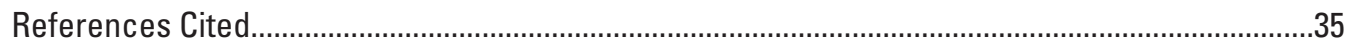

Appendix 1. Model Archival Summary for Chlorophyll Concentration at Milford Lake, May 26, June 9 , July 14 , July 21 , and September 15, 2016. Available online only at https://doi.org/10.3133/sir20185166

Appendix 2. Model Archival Summary for Total Microcystin Concentration at Milford Lake, May 26, June 9, July 14, July 21, and September 15, 2016. Available online only at https://doi.org/10.3133/sir20185166 


\section{Figures}

1. Maps of Milford Lake, including the location of all study sites .3

2. Graphs showing comparison between 0.5-meter depth sensor-measured phycocyanin and laboratory-measured chlorophyll and microcystin from data collections on May 26, June 9, July 14, July 21, and September 15, 2017.

3. Time-lapse camera images showing cyanobacterial harmful algal bloom (CyanoHAB) variability in Milford Lake during July 2016

4. Bar graph showing phytoplankton abundance, community composition, and algal biomass (as indicated by chlorophyll concentration) at the Wakefield site at Milford Lake during May through November 2016.

5. Bar graph showing cyanobacterial abundance, community composition, and microcystin concentration at the Wakefield site at Milford Lake during May through November 2016

6. Chart showing regression-estimated microcystin concentrations at the Wakefield site at Milford Lake and Kansas Department of Health and Environment posted lake status during May through November 2016.

7. Map showing discrete phytoplankton and cyanobacterial abundances and chlorophyll and microcystin concentrations in Zone $\mathrm{C}$ of Milford Lake on May 26, 2016

8. Diagrams showing regression-estimated chlorophyll concentrations at a 0.5-meter depth in Zone C of Milford Lake on May 26, 2016.

9. Diagrams showing regression-estimated microcystin concentrations at a 0.5-meter depth in Zone C of Milford Lake on May 26, 2016.

10. Map showing discrete phytoplankton and cyanobacterial abundances and chlorophyll and microcystin concentrations in Zone $\mathrm{C}$ of Milford Lake on July 21, 2016

11. Diagrams showing regression-estimated chlorophyll concentrations at a 0.5-meter depth in Zone C of Milford Lake on July 21, 2016

12. Diagrams showing regression-estimated microcystin concentrations at a 0.5 meter depth in Zone C of Milford Lake on July 21, 2016.

13. Map showing discrete phytoplankton and cyanobacterial abundances and chlorophyll and microcystin concentrations in Zone $\mathrm{C}$ of Milford Lake on September 15, 2016.

14. Diagrams showing regression-estimated chlorophyll concentrations at a 0.5 meter depth in Zone C of Milford Lake on September 15, 2016.

15. Diagrams showing regression-estimated chlorophyll concentrations at a 1.5 meter depth in Zone C of Milford Lake on September 15, 2016

16. Diagrams showing regression-estimated microcystin concentrations at a 0.5 meter depth in Zone C of Milford Lake on September 15, 2016.

17. Diagrams showing regression-estimated microcystin concentration at a 1.5-meter depth in Zone C of Milford Lake on September 15, 2016 


\section{Tables}

1. Milford Lake discrete water-quality sampling sites, including analyses and dates sampled...6

2. Summary statistics for regression-estimated chlorophyll and microcystin concentrations at the Wakefield site at Milford Lake during May through November 2016.

3. Weekly comparison of sensor-measured phycocyanin and regression-estimated microcystin concentrations at the continuous water-quality monitor at Milford Lake near Wakefield, Kansas, and Kansas Department of Health and Environment lake status.

4. Summary statistics for regression-estimated chlorophyll and microcystin concentrations in Zone C of Milford Lake on May 26, 2016.

5. Summary statistics for regression-estimated chlorophyll and microcystin concentrations in Zone C of Milford Lake on July 21, 2016

6. Summary statistics for regression-estimated chlorophyll and microcystin concentrations in Zone C of Milford Lake on September 15, 2016.

\section{Conversion Factors}

International System of Units to U.S. customary units

\begin{tabular}{|c|c|c|}
\hline Multiply & By & To obtain \\
\hline \multicolumn{3}{|c|}{ Length } \\
\hline millimeter $(\mathrm{mm})$ & 0.03937 & inch (in.) \\
\hline meter (m) & 3.281 & foot $(\mathrm{ft})$ \\
\hline kilometer (km) & 0.6214 & mile (mi) \\
\hline \multicolumn{3}{|c|}{ Area } \\
\hline square kilometer $\left(\mathrm{km}^{2}\right)$ & 0.3861 & square mile $\left(\mathrm{mi}^{2}\right)$ \\
\hline \multicolumn{3}{|c|}{ Volume } \\
\hline milliliter $(\mathrm{mL})$ & 0.0338 & ounce, fluid (oz) \\
\hline liter (L) & 0.2642 & gallon (gal) \\
\hline cubic hectometer $\left(\mathrm{hm}^{3}\right)$ & 810.7 & acre-foot (acre-ft) \\
\hline \multicolumn{3}{|c|}{ Flow rate } \\
\hline meter per second $(\mathrm{m} / \mathrm{s})$ & 3.281 & foot per second (ft/s) \\
\hline cubic meter per second $\left(\mathrm{m}^{3} / \mathrm{s}\right)$ & 35.31 & cubic foot per second $\left(\mathrm{ft}^{3} / \mathrm{s}\right)$ \\
\hline \multicolumn{3}{|c|}{ Mass } \\
\hline microgram $(\mu \mathrm{g})$ & 0.00000003527 & ounce, avoirdupois, (oz) \\
\hline
\end{tabular}

Temperature in degrees Celsius $\left({ }^{\circ} \mathrm{C}\right)$ may be converted to degrees Fahrenheit $\left({ }^{\circ} \mathrm{F}\right)$ as follows:

${ }^{\circ} \mathrm{F}=\left(1.8 \times{ }^{\circ} \mathrm{C}\right)+32$. 


\section{Datum}

Horizontal and vertical coordinate information is referenced to the North American Datum of 1983 (NAD 83).

\section{Supplemental Information}

Concentrations of chemical constituents in water are given in micrograms per liter $(\mu \mathrm{g} / \mathrm{L})$.

\begin{tabular}{ll}
\multicolumn{2}{l}{ Abbreviations } \\
CyanoHAB & cyanobacterial harmful algal bloom \\
KDHE & Kansas Department of Health and Environment \\
NWIS & National Water Information System \\
RFU & relative fluorescence units \\
USGS & U.S. Geological Survey \\
YSI & Yellow Springs Instruments
\end{tabular}




\title{
Spatial and Temporal Variability of Harmful Algal Blooms in Milford Lake, Kansas, May through November 2016
}

\author{
By Guy M. Foster, Jennifer L. Graham, and Lindsey R. King
}

\section{Abstract}

The U.S. Geological Survey, in cooperation with the Kansas Department of Health and Environment (KDHE), completed a study to quantify the spatial and temporal variability of cyanobacterial blooms in Milford Lake, Kansas, over a range of environmental conditions at various time scales (hours to months). A better understanding of the spatial and temporal variability of cyanobacteria and microcystin will inform sampling and management strategies for Milford Lake and for other lakes with cyanobacterial harmful algal bloom (CyanoHAB) issues throughout the Nation. Spatial and temporal variability were assessed in the upstream one-third of Milford Lake (designated as "Zone C" by KDHE) during May through November 2016 using a combination of timelapse photography, continuous water-quality monitors, discrete phytoplankton, chlorophyll, and microcystin samples, and spatially dense near-surface data. Combined, these data were used to characterize variability of cyanobacterial abundance, algal biomass, and microcystin concentrations in Zone $\mathrm{C}$ of Milford Lake before, during, and after cyanobacterial blooms in 2016.

Temporal patterns were evaluated during May through November 2016 using time-lapse photography at six locations in Zone $\mathrm{C}$ and at a single point location (the Wakefield site) using a combination of discrete and continuously measured water-quality data (including the cyanobacterial pigment phycocyanin). Based on time-lapse photography, CyanoHABs developed in Zone C of Milford Lake in early July and persisted through the end of November. Bloom accumulations at individual sites were dependent on wind direction. After a change in wind direction, it would take about 1 day for accumulations to become visible at different locations. During periods with low wind, accumulations were widespread and visible at all sites. Cyanobacteria were absent from the algal community at the Wakefield site in late May and were a minor component of the community in June; however, by mid-July the cyanobacteria were dominant and remained dominant until early November.

Chlorophyll and microcystin concentrations at the Wakefield site were estimated using sensor-measured phycocyanin based on regression models developed for Zone C. Regression-estimated concentrations likely are more indicative of seasonal patterns in algal biomass (as indicated by chlorophyll concentrations) and microcystin than discretely collected samples because regression-estimated data have a much higher temporal resolution. Based on regression estimates, algal biomass and microcystin concentrations at the Wakefield site steadily increased from May through August. After August, concentrations decreased but remained relatively high compared to May and June. Daily chlorophyll maxima were as much as 400 times higher than daily minima, and daily microcystin maxima were as many as several orders of magnitude higher than daily minima. The extreme variability in algal biomass and microcystin concentrations at the Wakefield site reflects the development and dissipation of blooms, as indicated by the time-lapse cameras.

Based on regression-estimated microcystin concentrations, the KDHE watch and warning thresholds for microcystin were exceeded during mid-June through late November. Exceedance of KDHE advisory thresholds often changed from no advisory to watch or warning over the course of the day because of the variability in algal biomass and microcystin concentrations caused by bloom development and dissipation. Continuous water-quality monitors may be useful in informing public-health decisions in lakes with variable CyanoHAB conditions; however, site-specific models need to be developed, and best practices for using continuous waterquality monitors to inform CyanoHAB management strategies need to be established.

Spatial data were collected on May 26, July 21, and September 15, 2016, using a combination of a boat-mounted array and discrete water-quality samples analyzed for phytoplankton community composition and chlorophyll and microcystin concentrations. Spatial patterns were described using regression-estimated chlorophyll and microcystin concentrations. During the May 26, 2016, spatial surveys, cyanobacterial abundances were relatively low throughout Zone $\mathrm{C}$ and did not exceed KDHE guidance values compared to spatial surveys on July 21 and September 15. Regression-estimated chlorophyll concentrations were indicative of higher algal biomass uplake in Zone $\mathrm{C}$, and decreases in the downlake direction towards Zone B. 
Regression-estimated chlorophyll concentrations also were more variable uplake than downlake. Based on regression estimates, microcystin concentrations did not exceed KDHE guidance values anywhere in Zone C on May 26. Spatial patterns in microcystin throughout Zone $\mathrm{C}$ did not match patterns in regression-estimated chlorophyll concentrations, likely because the algal community was not dominated by cyanobacteria at most locations in May.

During the July 21, 2016, spatial surveys, cyanobacterial abundances in Zone $\mathrm{C}$ exceeded KDHE guidance values in 50 percent of samples. The algal community in Zone C was dominated by cyanobacteria at all locations except two, where cyanobacteria codominated with diatoms. Both locations where cyanobacteria and diatoms codominated were north of the causeway. Regression-estimated chlorophyll concentrations were indicative of higher algal biomass north of the causeway and on the eastern shore of Zone C. On July 21, algal biomass did not always decrease in the downlake direction. There was a decrease just south of the causeway but an increase shortly after with higher concentrations into Zone B. Spatial maps indicated changes in algal distribution at a 0.5 -meter depth, with algae moving to the central part of the lake north of the causeway and along the eastern shore south of the causeway. Most regressionestimated microcystin concentrations on July 21 exceeded KDHE guidance values, reflecting the pervasive bloom conditions in Zone C during this period. Spatial patterns in regression-estimated microcystin concentrations throughout Zone $\mathrm{C}$ were similar to patterns seen in discrete samples and regression-estimated chlorophyll concentrations, with higher concentrations north of the causeway and on the east shore of Zone C.

During the September 15, 2016, spatial surveys, cyanobacterial abundances did not exceed KDHE guidance values. The algal community north of the causeway was dominated by diatoms. The algal community throughout the rest of Zone $\mathrm{C}$ was dominated by cyanobacteria. Of regression-estimated microcystin concentrations on September 15, 80 percent did not exceed KDHE guidance values. Spatial patterns indicated northward movement of the cyanobacterial bloom consistent with a wind shift noted the previous day. On September 14, winds were generally from the north to northwest, shifting to the south by September 15 . There was a northward progression of chlorophyll and microcystin during the spatial surveys. These data, along with the camera data and spatial and wind data from May and July, indicate that wind can be a major driver of the spatial and temporal variability of cyanobacterial blooms in Milford Lake and likely plays a role in the extent and duration of near-shore accumulations.

\section{Introduction}

Problems associated with cyanobacterial harmful algal blooms (CyanoHABs) include reductions in water quality, malodorous accumulations along shorelines, production of taste-and-odor compounds that cause unpalatable drinking water and fish flesh, and production of toxins potent enough to poison aquatic and terrestrial organisms. Cyanobacterial toxins (hereafter referred to as "cyanotoxins") have been implicated in human illness and animal deaths in at least 43 States in the United States (Graham and others, 2016). The past several decades have seen an apparent worldwide increase in toxic CyanoHABs (O'Neil and others, 2012). Cyanobacterial bloom development is affected by many interacting physical, chemical, and biological factors, and there is no single cause of blooms (Graham and others, 2016). Humans are most frequently exposed to cyanotoxins through recreational activities. Many States, including Kansas, have established monitoring programs for recreational water bodies to protect public health (Graham and others, 2009). Milford Lake, in northeast Kansas, has been under Kansas Department of Health and Environment (KDHE) CyanoHAB advisories every summer since 2011 . The only part of the lake that has experienced blooms severe enough to warrant closure is the upstream one-third that has been designated as "Zone C" by KDHE (fig. 1) (Kansas Department of Health and Environment, 2016, 2017).

The KDHE uses three guidance levels to issue recreational public-health advisories for CyanoHABs in Kansas lakes. The current (2018) guidance levels for publichealth watches are cyanobacterial abundances ranging from 80,000 to less than 250,000 cells per milliliter (cells $/ \mathrm{mL}$ ) or microcystin (a common cyanotoxin) concentrations ranging from 4 to less than 20 micrograms per liter $(\mu \mathrm{g} / \mathrm{L})$. The current (2018) guidance for public-health warnings is cyanobacterial abundances from 250,000 to less than 10,000,000 cells/ $\mathrm{mL}$ or microcystin concentrations from 20 to less than $2,000 \mu \mathrm{g} / \mathrm{L}$. Lake closures can result from cyanobacterial abundances or microcystin concentrations greater than or equal to $10,000,000$ cells $/ \mathrm{mL}$ or greater than or equal to $2,000 \mu \mathrm{g} / \mathrm{L}$, respectively (Kansas Department of Health and Environment, 2015).

Extreme spatial and temporal variability is characteristic of CyanoHABs. Because of inlake and weather-driven processes, CyanoHABs can vary by orders of magnitude in concentration across short distances (meters or less) (Foster and others, 2017). The U.S. Geological Survey (USGS), in cooperation with KDHE, characterized the spatial variability of cyanobacteria and microcystin in Milford Lake during July and August 2015 (Foster and others, 2017). Results indicated that cyanobacterial biomass and microcystin concentrations were higher in Zone $\mathrm{C}$ than the downlake zones ("Zones A and B"), decreased in the downlake direction, and exhibited the extreme spatial variability characteristic of cyanobacterial blooms. However, summer 2015 findings were based on two daylong lake surveys with similar environmental and CyanoHAB conditions. The objectives of the 2016 study were to quantify the spatial variability of cyanobacterial blooms in Zone $\mathrm{C}$ over a range of environmental conditions and quantify the temporal variability of blooms in Zone $\mathrm{C}$ at various time scales (hours to months). A better understanding of the spatial and temporal variability of cyanobacteria and microcystin will inform sampling and management strategies for Milford Lake and for other lakes with CyanoHAB issues throughout the Nation. 


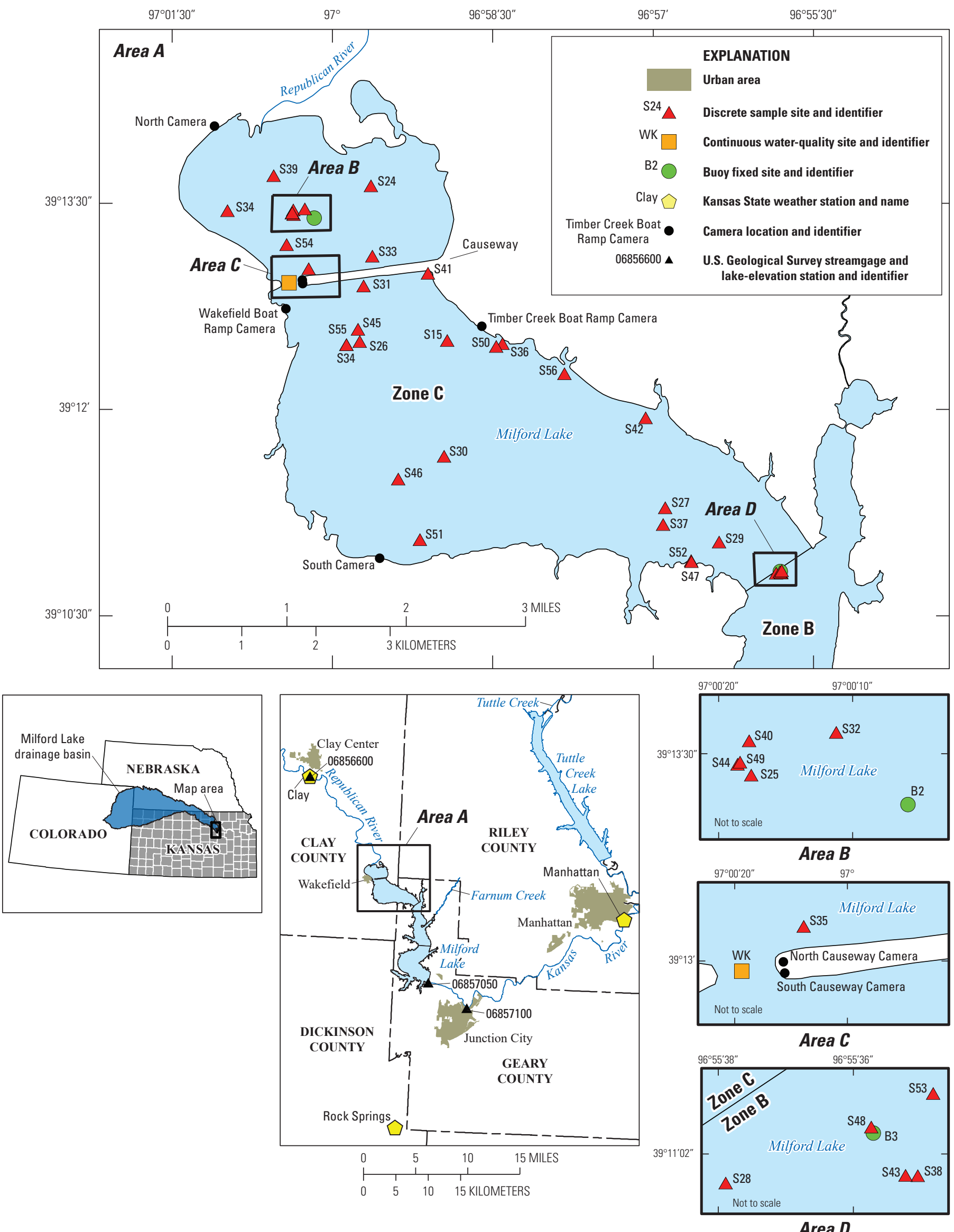

Area D

Figure 1. Milford Lake, including the location of all study sites. 


\section{Purpose and Scope}

The purpose of this report is to present the results of a USGS study to assess the spatial and temporal variability of cyanobacteria and microcystin in Zone C of Milford Lake, Kansas. Zone $\mathrm{C}$ was the focus of this study because cyanobacterial blooms in Milford Lake are most severe in this zone, and it is believed that blooms begin in this area and are transported to downstream locations in the reservoir (Foster and others, 2017). Spatial and temporal variability of conditions before, during, and after cyanobacterial blooms were assessed during May through November 2016 using a combination of time-lapse photography; continuous waterquality monitors; discrete phytoplankton, chlorophyll, and microcystin samples; and spatially dense near-surface data. Combined, these data were used to characterize the variability of cyanobacterial abundance, algal biomass (as indicated by chlorophyll), and microcystin concentrations in Zone $\mathrm{C}$ of Milford Lake before, during, and after cyanobacterial blooms in 2016.

\section{Description of Study Area}

Milford Lake, the largest lake in Kansas, is a reservoir that was completed in 1967 by the U.S. Army Corps of Engineers for the purposes of flood control, water supply, water quality, navigation, recreation, and wildlife (Kansas Water Office, 2017) (fig. 1). Milford Lake has a drainage area of about 64,400 square kilometers $\left(\mathrm{km}^{2}\right)$. The Republican River (fig. 1) is the primary inflow to Milford Lake and drains areas of Kansas, Nebraska, and Colorado. Based on design specifications, at the conservation pool elevation (348.8 meters [m] above North American Datum of 1983 [NAD 83]), Milford Lake has a surface area of about $63 \mathrm{~km}^{2}$, a maximum depth of about $20 \mathrm{~m}$, an average depth of about $7.6 \mathrm{~m}$, and a volume of about 460 cubic hectometers $\left(\mathrm{hm}^{3}\right)$. This study focused on Zone $\mathrm{C}$ of Milford Lake, which has a surface area of about $25 \mathrm{~km}^{2}$ at the conservation pool. A more detailed description of the general limnology, water quality, and KDHE zone system of Milford Lake is in Foster and others (2017).

\section{Methods}

Spatial and temporal variability of cyanobacterial blooms in Zone C of Milford Lake was assessed during May 25 through November 28, 2016. Data collection included a combination of time-lapse photography; continuous waterquality monitors; discrete phytoplankton, chlorophyll, and microcystin samples; and spatially dense near-surface surveys. All data are available through the USGS National Water Information System (NWIS) (U.S. Geological Survey, 2018) and in King (2018a, b, c, and d).

\section{Time-Lapse Photography}

A total of six time-lapse cameras (Wingscape model WCT-00125) were deployed at various locations around Zone C (fig. 1) from June 29 to November 28, 2016, to visually capture images of cyanobacterial accumulations and movement. Because of site accessibility and equipment issues, images from the south camera (fig. 1) were only available from July 28 to August 3, 2016. The cameras collected 8 Megapixel, 2,304 $\times 1,728$ resolution images in JPEG format, stored on an internal secure digital (SD) memory card. Cameras were initially set to collect hourly images on June 29 but were increased to every 5 minutes starting July 21 to better capture the temporal variability observed in the previously collected images. Cameras were programmed to only collect daytime images and were inspected by field personnel approximately monthly. Inspections included any necessary lens cleaning, clearing of any interfering brush that grew in front of the camera, and downloading images. Usable images (for example, those not obscured by fog, insects, rain events, or brush) were individually examined for cyanobacterial accumulation and movement. All images and time-lapse camera videos are available in King (2018c).

\section{Continuous Water-Quality Site-Milford Lake near Wakefield, Kansas}

Continuous (15-minute interval) water-quality data were collected at USGS site 391259097001800, Milford Lake near Wakefield, Kans. (hereinafter referred to as "Wakefield" and site identifier is "WK"). The site was operated from May 25 through November 28, 2016, and was on the Highway 82 Bridge east of Wakefield in Clay County, Kans. (fig. 1). A Yellow Springs Instruments (YSI) EXO2 multiparameter water-quality monitor (Yellow Springs Instruments, 2017) was installed for measuring water temperature, specific conductance, dissolved oxygen, $\mathrm{pH}$, turbidity, colored dissolved organic matter fluorescence (fDOM), chlorophyll fluorescence, and phycocyanin fluorescence. The water-quality monitor was suspended from the bridge within the photic zone (typically at a depth between 0.5 and $1.0 \mathrm{~m}$ below the water surface) and was maintained in accordance with standard USGS procedures (Wagner and others, 2006; Bennett and others, 2014). Continuous water-quality data are available through NWIS (U.S. Geological Survey, 2018). 
Sensor maxima were not exceeded for any of the constituents measured except phycocyanin fluorescence (YSI EXO2; operable range from 0 to 100 relative fluorescence units [RFU] and 0 to 100 micrograms per liter). Exceedances were occasionally observed during July 9 through September 1 when bloom conditions were most severe. About 87 percent of the continuous data were rated as excellent (requiring corrections of less than plus or minus $[ \pm] 5$ percent), 7 percent were rated as good (requiring corrections of less than \pm 10 percent), 5 percent were rated as fair (requiring corrections of less than \pm 15 percent), and 1 percent were rated as poor (requiring corrections of greater than \pm 15 percent) according to established guidelines set for turbidity, which is another optical sensor prone to similar variability in environmental settings (Wagner and others, 2006).

Water-quality measurements occasionally were missing or deleted from the dataset because of equipment malfunction or excessive fouling caused by environmental conditions. About 9 percent of the water temperature record, 10 percent of the specific conductance record, 25 percent of the dissolved oxygen record, 12 percent of the $\mathrm{pH}$ record, 21 percent of the turbidity record, 32 percent of the colored dissolved organic matter fluorescence record, 3 percent of the chlorophyll fluorescence record, and 19 percent of the phycocyanin fluorescence record were missing or deleted. However, because of the dynamic nature of cyanobacterial blooms in Milford Lake, much of the extreme variability in the chlorophyll fluorescence, phycocyanin fluorescence, and turbidity data was left intact, despite seeming erratic or potentially fouled. Phycocyanin was the only constituent used in final analyses because it is an indicator of cyanobacteria and has previously been used to estimate algal biomass and microcystin concentrations in Milford Lake (Foster and others, 2017). Results for other measured constituents are not described in this report.

\section{Discrete Sample Collection and Analysis}

A total of 53 discrete water-quality samples were collected throughout Milford Lake during May through November 2016. A total of 8 samples were collected at the Wakefield site, 28 samples were collected during the 3 spatial surveys, and an additional 17 samples were collected during other data collections and used in the development of regression models (see "Data Analysis" section of the report). Discrete water-quality samples were collected near the continuous water-quality monitor as either near-surface grabs using a weighted basket or near the continuous waterquality monitor (between 0.5 and $1.0 \mathrm{~m}$ ) using a $\mathrm{DH}-81$ sampler with a Teflon collar and a 1-liter (L) Teflon bottle (U.S. Geological Survey, variously dated; Wilde and others, 2014). During spatial data collections, discrete sample locations were not predetermined, and samples were split evenly among the spatial surveys. An exception to this approach happened on July 14, when samples were collected at three sites used during the Foster and others (2017) study.
Open-water sampling locations throughout Zone $\mathrm{C}$ were selected to represent the range of bloom conditions based on visual cues and continuous water-quality monitor data (table 1 , fig. 1). Discrete samples during spatial data collections were obtained at the location of the boat-mounted water-quality monitor (about a $0.5-\mathrm{m}$ depth) using a DH-81 sampler with a Teflon collar and a 1-L Teflon bottle (U.S. Geological Survey, variously dated; Wilde and others, 2014). An exception to this approach was on July 14, when samples also were collected as near-surface grabs, at a $0.5-\mathrm{m}$ depth using a Van Dorn sampler, or depth integrated from the surface to $0.5 \mathrm{~m}$ using a peristaltic pump (Graham and others, 2008; Wilde and others, 2014). All samples were immediately processed in the field and analyzed for phytoplankton community composition and chlorophyll and total microcystin (hereinafter referred to as "microcystin") concentrations as described in Foster and others (2017). Chlorophyll and microcystin data are available through NWIS (U.S. Geological Survey, 2018) and phytoplankton data are available in King (2018b).

\section{Spatial Data Collection}

Spatial data were collected on May 26, June 9, July 14, July 21, and September 15, 2016, using YSI EXO2 multiparameter water-quality monitors mounted underneath the boat at about $0.5-$ and $1.5-\mathrm{m}$ depths as described in Foster and others (2017). Only one depth $(0.5 \mathrm{~m})$ was used for all surveys except September 15 because vertical profiles exhibited little variability throughout the water column the day before, and excluding the $1.5-\mathrm{m}$ depth allowed the boat to sample more of Zone $\mathrm{C}$ because of the overall shallower depth north of the causeway. Both depths (0.5- and 1.5 -m depths) were used on September 15, 2016, because vertical profiles the day before exhibited higher variability throughout the water column. A total of two consecutive spatial surveys following the same route throughout Zone C were completed on May 26, July 14, and September 15 to characterize changing conditions throughout the course of the day. To capture potential diurnal variability at fixed-site locations (other than Wakefield) during the spatial surveys, two data collection buoys with YSI EXO2 multiparameter water-quality monitors at about a $1.0-\mathrm{m}$ depth were deployed. Buoys were placed near the causeway in Zone C ("B2") and at the boundary of Zones B and C ("B3") (table 1, fig. 1) except during June 9, when a buoy was placed only at "B3" and July 14, when buoys were not deployed. All spatial data were used in regression model development; however, only data collected on May 26, July 21, and September 15 had the spatial coverage required for a complete analysis of Zone $\mathrm{C}$ and are described in this report. As described for the Wakefield site, phycocyanin was the only water-quality constituent used in final analyses. Results for other measured constituents are not described in this report. Buoy data also are not described in this report because these data did not add substantially to interpretation and analysis. All spatial and buoy water-quality data collected as part of this study are available in King (2018a, d). 
Table 1. Milford Lake discrete water-quality sampling sites, including analyses and dates sampled.

[KS, Kansas; FCWQ, fixed continuous water-quality site with no discrete data; MC, total microcystin; Chl, chlorophyll; PHYTO, phytoplankton; Alk, field alkalinity; UV254, ultraviolet absorbing organic constituents]

\begin{tabular}{|c|c|c|c|c|}
\hline Site identifier & Site name & Number & Sample analysis & Sample date \\
\hline WK & $\begin{array}{l}\text { Milford Lake near Wakefield, } \\
\text { KS }\end{array}$ & 391259097001800 & $\begin{array}{l}\text { FCWQ, MC, Chl, } \\
\text { PHYTO, Alk, } \\
\text { UV254 }\end{array}$ & $\begin{array}{l}\text { 5/25/2016, 6/8/2016, 6/27/2016, 7/14/2016, } \\
8 / 2 / 2016,9 / 1 / 2016,11 / 2 / 2016\end{array}$ \\
\hline S22 & Milford Lake, KS, site 22 & 390527096543400 & MC, Chl, PHYTO & $7 / 14 / 2016$ \\
\hline S24 & Milford Lake, KS, site 24 & 391343096593400 & MC, Chl, PHYTO & $5 / 26 / 2016$ \\
\hline S25 & Milford Lake, KS, site 25 & 391329097001700 & MC, Chl, PHYTO & $5 / 26 / 2016$ \\
\hline S26 & Milford Lake, KS, site 26 & 391235096593700 & MC, Chl, PHYTO & $5 / 26 / 2016$ \\
\hline S27 & Milford Lake, KS, site 27 & 391128096564200 & MC, Chl, PHYTO & $5 / 26 / 2016$ \\
\hline S28 & Milford Lake, KS, site 28 & 391102096553800 & MC, Chl, PHYTO & $5 / 26 / 2016$ \\
\hline S29 & Milford Lake, KS, site 29 & 391114096561000 & MC, Chl, PHYTO & $5 / 26 / 2016$ \\
\hline $\mathrm{S} 30$ & Milford Lake, KS, site 30 & 391146096584700 & MC, Chl, PHYTO & $5 / 26 / 2016$ \\
\hline S31 & Milford Lake, KS, site 31 & 391259096593600 & MC, Chl, PHYTO & $5 / 26 / 2016$ \\
\hline S32 & Milford Lake, KS, site 32 & 391332097001100 & MC, Chl, PHYTO & 6/9/2016 \\
\hline S33 & Milford Lake, KS, site 33 & 391312096593200 & MC, Chl, PHYTO & 6/9/2016 \\
\hline S34 & Milford Lake, KS, site 34 & 391329097005400 & MC, Chl, PHYTO & $7 / 21 / 2016$ \\
\hline S35 & Milford Lake, KS, site 35 & 391306097000700 & MC, Chl, PHYTO & $7 / 21 / 2016$ \\
\hline S36 & Milford Lake, KS, site 36 & 391237096581700 & MC, Chl, PHYTO & $7 / 21 / 2016$ \\
\hline S37 & Milford Lake, KS, site 37 & 391121096564200 & MC, Chl, PHYTO & $7 / 21 / 2016$ \\
\hline S38 & Milford Lake, KS, site 38 & 391105096553500 & MC, Chl, PHYTO & $7 / 21 / 2016$ \\
\hline S39 & Milford Lake, KS, site 39 & 391345097002900 & MC, Chl, PHYTO & $7 / 21 / 2016$ \\
\hline S40 & Milford Lake, KS, site 40 & 391331097001700 & MC, Chl, PHYTO & $7 / 21 / 2016$ \\
\hline S41 & Milford Lake, KS, site 41 & 391306096590000 & MC, Chl, PHYTO & $7 / 21 / 2016$ \\
\hline S42 & Milford Lake, KS, site 42 & 391207096565500 & MC, Chl, PHYTO & $7 / 21 / 2016$ \\
\hline S43 & Milford Lake, KS, site 43 & 391102096553501 & MC, Chl, PHYTO & $7 / 21 / 2016$ \\
\hline S44 & Milford Lake, KS, site 44 & 391330097001800 & MC, Chl, PHYTO & $9 / 15 / 2016$ \\
\hline S45 & Milford Lake, KS, site 45 & 391240096593800 & MC, Chl, PHYTO & $9 / 15 / 2016$ \\
\hline S46 & Milford Lake, KS, site 46 & 391135096591200 & MC, Chl, PHYTO & $9 / 15 / 2016$ \\
\hline S47 & Milford Lake, KS, site 47 & 391106096591200 & MC, Chl, PHYTO & $9 / 15 / 2016$ \\
\hline S48 & Milford Lake, KS, site 48 & 391102096591200 & MC, Chl, PHYTO & $9 / 15 / 2016$ \\
\hline S49 & Milford Lake, KS, site 49 & 391330097001801 & MC, Chl, PHYTO & $9 / 15 / 2016$ \\
\hline S50 & Milford Lake, KS, site 50 & 391235096582000 & MC, Chl, PHYTO & $9 / 15 / 2016$ \\
\hline S51 & Milford Lake, KS, site 51 & 391109096585800 & MC, Chl, PHYTO & $9 / 15 / 2016$ \\
\hline S52 & Milford Lake, KS, site 52 & 391105096562600 & MC, Chl, PHYTO & $9 / 15 / 2016$ \\
\hline S53 & Milford Lake, KS, site 53 & 391103096553500 & MC, Chl, PHYTO & $9 / 15 / 2016$ \\
\hline S54 & Milford Lake, KS, site 54 & 391316097002000 & РHYTO & $11 / 28 / 2016$ \\
\hline S55 & Milford Lake, KS, site 55 & 391233096594400 & PHYTO & $11 / 28 / 2016$ \\
\hline S56 & Milford Lake, KS, site 56 & 391225096574100 & PHYTO & $11 / 28 / 2016$ \\
\hline B2 & Milford Lake, KS, fixed site 2 & 390610096555501 & FCWQ & $\begin{array}{l}\text { 5/25/2016-5/26/2016, 6/8/2016-6/10/2016, } \\
7 / 20 / 2016-7 / 21 / 2016,9 / 14 / 2016-9 / 15 / 2016\end{array}$ \\
\hline B3 & Milford Lake, KS, fixed site 3 & 391102096553502 & FCWQ & $\begin{array}{l}5 / 25 / 2016-5 / 26 / 2016,6 / 8 / 2016-6 / 10 / 2016 \\
7 / 20 / 2016-7 / 21 / 2016,9 / 14 / 2016-9 / 15 / 2016\end{array}$ \\
\hline
\end{tabular}




\section{Ancillary Data}

The three weather stations that bracket Milford Lake (Rock Springs, Clay, and Manhattan; fig. 1), operated and maintained by Kansas State University, were used to describe air temperature, wind speed and direction, and rainfall the day before and the day of spatial data collection. Data from all three stations were averaged to describe general weather conditions (Kansas State University, 2016). To display wind data, wind rose diagrams that depict the relative frequency and cardinal direction of wind origination were created in Microsoft ${ }^{\circledR}$ Excel. Wind rose diagrams should be interpreted like a compass to assess the dominant wind direction on a given day. The greater the relative frequency, the farther the data plot from the center of the diagram.

Two USGS streamflow-gaging stations (USGS site 06856600, Republican River at Clay Center, Kans., and USGS site 06857100, Republican River at Junction City, Kans.) and one USGS lake-elevation gaging station (USGS site 06857050, Milford Lake near Junction City, Kans.) (fig. 1) were used to describe lake inflows, outflows, and elevation and storage volume of Milford Lake, respectively, the week before each spatial survey. Streamflow and lake elevation were measured using standard USGS methods (Sauer and Turnipseed, 2010; Turnipseed and Sauer, 2010) and are available through NWIS (U.S. Geological Survey, 2018).

\section{Data Analysis}

Ordinary least-squares analysis (Helsel and Hirsch, 2002) was used to develop regression models between phycocyanin RFU measured by the $0.5-\mathrm{m}$ depth sensor and laboratory-measured chlorophyll and microcystin concentrations as described in Foster and others (2017). Prediction intervals were calculated in Sigma Plot (version 13) to quantify uncertainty in regression estimated chlorophyll and microcystin concentrations (Neter and others, 1996). Confidence level for prediction intervals was set to 95 (95 percent prediction interval). Data collected from all spatial surveys were combined for regression analyses. There was a poor linear association between sensor-measured phycocyanin RFU and cyanobacterial abundance, as indicated by the coefficient of determination $\left(R^{2}\right)\left(R^{2}=0.35\right.$; number of values $[n]=34)$. By comparison, there were strong linear associations between sensor-measured phycocyanin RFU and laboratorymeasured chlorophyll and microcystin concentrations (fig. 2). Phycocyanin RFU explained 94 and 87 percent of the variance in laboratory-measured chlorophyll and microcystin concentrations, respectively, as indicated by the coefficient of determination $\left(R^{2}\right)$. Chlorophyll and phycocyanin are algal pigments that are maintained intracellularly. All photosynthetic organisms, including algae and cyanobacteria, contain chlorophyll; however, the phycocyanin pigment is only indicative of cyanobacteria (Hambrook Berkman and Canova, 2007). Phycocyanin may have been the best explanatory variable for laboratory-measured chlorophyll and microcystin concentrations during this study because the algal community in Milford Lake was almost exclusively cyanobacteria during summer months (Foster and others, 2017).

Chlorophyll and microcystin concentrations in Milford Lake at the $0.5-\mathrm{m}$ depth for the spatial data collection runs ( 0.5 and $1.5 \mathrm{~m}$ for September 15) were estimated using phycocyanin RFU data collected with the mounted sensor array and the regression models developed using phycocyanin RFU data and laboratory-measured concentrations. Details of the regression models used to estimate chlorophyll and microcystin concentrations are presented in appendixes 1 and 2. Applying the regression models to the phycocyanin RFU data collected at the $1.5-\mathrm{m}$ depth for the September 15,2016 , spatial survey assumes that the relation among sensor-measured phycocyanin RFU, laboratory-measured chlorophyll, and microcystin is the same as the relation developed for the $0.5-\mathrm{m}$ depth.

Regression-estimated values of chlorophyll were positive for all phycocyanin values collected during the spatial surveys, but regression-estimated values of microcystin were negative for phycocyanin values less than $0.75 \mathrm{RFU}$. Therefore, regression-estimated microcystin concentrations at $0.75 \mathrm{RFU}(0.07 \mu \mathrm{g} / \mathrm{L})$ were used as the minimum reporting thresholds for regression-estimated data. Because of the focus on bloom conditions and the wide range of concentrations detected in Zone $\mathrm{C}$ of Milford Lake during this study, the lack of sensitivity of this model at low phycocyanin RFU values does not substantially affect observed spatial patterns in microcystin; however, these regression models are specific to the spatial data during this study and cannot be applied to the buoy data collected as part of this study, other data collected from Milford Lake, or data collected from other lakes. Although the models were not developed specifically for the Wakefield site, the regression-estimated concentrations likely are more indicative of seasonal patterns in algal biomass (indicated by chlorophyll) and microcystin than discretely collected samples.

Regression models were developed to characterize spatial variability in algal biomass (as indicated by chlorophyll) and microcystin concentrations in Zone C. Sufficient data were not collected to allow development of regression models specific to the Wakefield site. Regression models for the Wakefield site would allow characterization of temporal variability in algal biomass and microcystin concentrations. In particular, estimates of microcystin concentration would allow comparison with KDHE advisory levels. The Wakefield site is part of Zone C; therefore, for exploratory purposes, chlorophyll and microcystin concentrations were calculated at the Wakefield site using the spatial regression models. More rigorous models would need to be developed before chlorophyll and microcystin concentrations can be regression estimated in near real time at the Wakefield site for the purposes of public-health advisories or lake management. 

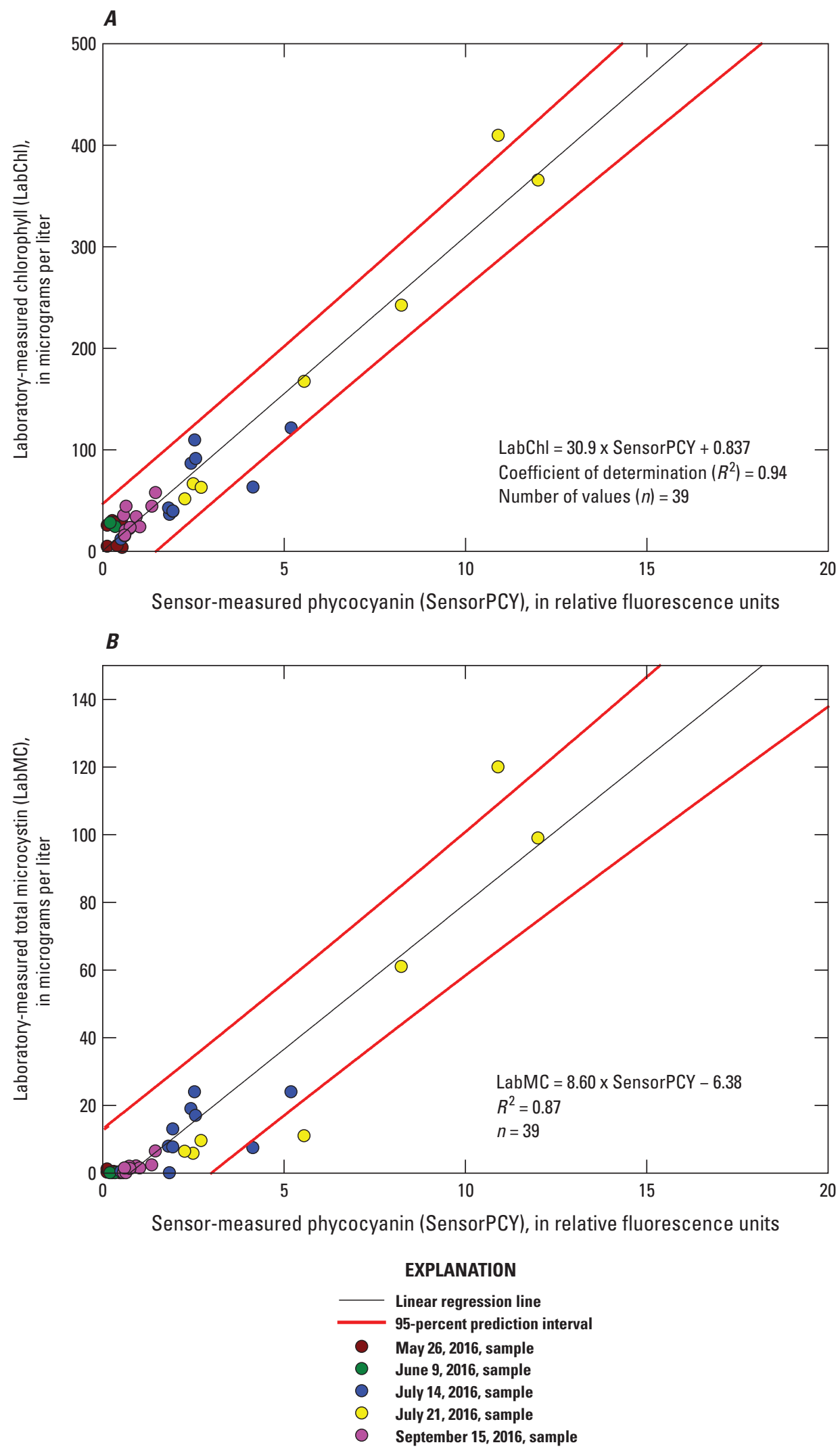

Figure 2. Comparison between 0.5-meter depth sensor-measured phycocyanin and laboratory-measured chlorophyll and microcystin from data collections on May 26, June 9, July 14, July 21, and September 15, 2017. A, the phycocyanin-chlorophyll comparison; and $B$, the phycocyanin-microcystin comparison. 
Maps of regression-estimated chlorophyll and microcystin concentrations in Milford Lake were generated from the spatial data collections using ArcGIS (version 10.5.1). Data were interpolated between points using the "Topo to Raster" tool in the "3-D Analyst Toolbox." The data points used the projected coordinate system "NAD_1983_2011_UTM_Zone_14N" and the Milford Lake boundary data from the National Hydrography Dataset (U.S. Geological Survey, 2013). A total of five natural class breaks were used to interpolate the data. To maintain the same scale for paired spatial data collection runs, the class breaks for the map with the greatest range were applied to paired maps. On May 26, 2016, regression-estimated microcystin concentrations were too low to generate an interpolation map, so only regression-estimated chlorophyll concentrations were mapped with interpolations.

\section{A. July 7, 2016, at 5 p.m.}

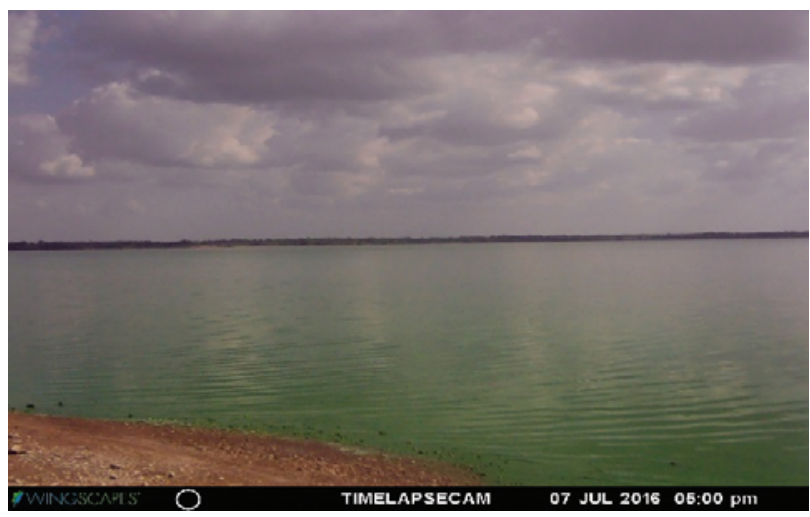

C. July 20, 2016, at 3:54 p.m.

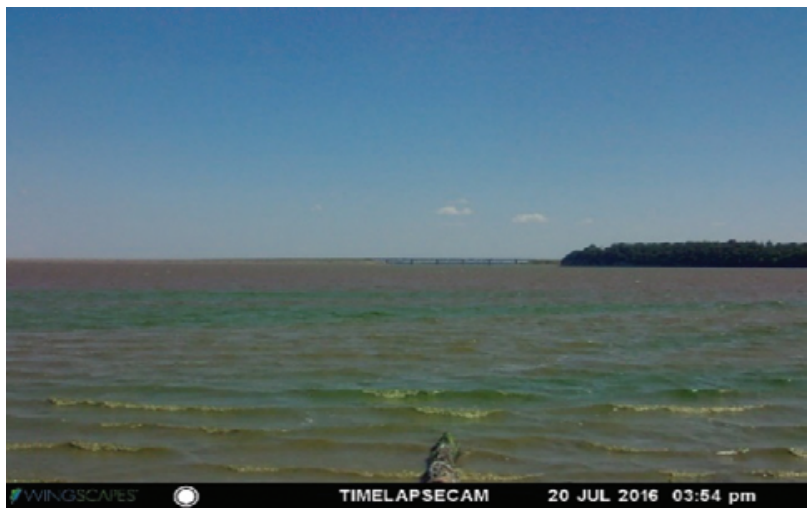

\section{Results for Time-Lapse Photography}

Time-lapse cameras were installed at six locations around Zone $\mathrm{C}$ of Milford Lake to visually capture the variability of cyanobacterial blooms, specifically accumulations (also referred to as "scums") from June 29 to November 28, 2016 (fig. 1). Cameras were initially set to take hourly images, but the image interval was changed to 5 minutes on July 21 to better capture changing bloom conditions. Blooms would appear at a location but over the course of an hour, would either move to another location or mix throughout the water column (fig. 3). Useable images from each camera were compiled and visually inspected to determine if cyanobacteria scums were present, possibly present (the analyst was not sure if scums were present because of interferences such as water-surface reflections and light incidence), or absent. Visible accumulations of cyanobacteria were present about one-half the time at sites with cameras. Cyanobacteria were in 48 percent of usable images $(n=30,733)$ across all sites, possibly in 14 percent of images $(n=8,915)$, and absent from 38 percent of images $(n=23,791)$.

\section{B. July 7, 2016, at 6 p.m.}

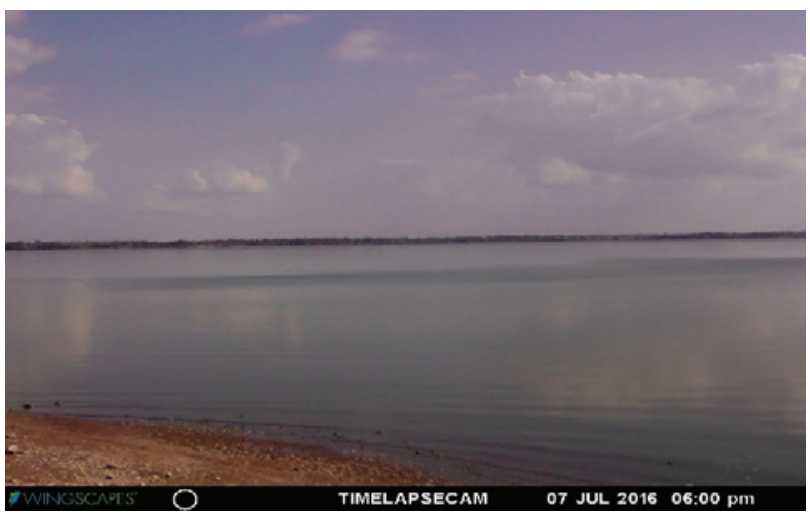

\section{July 20, 2016, at 4:09 p.m.}

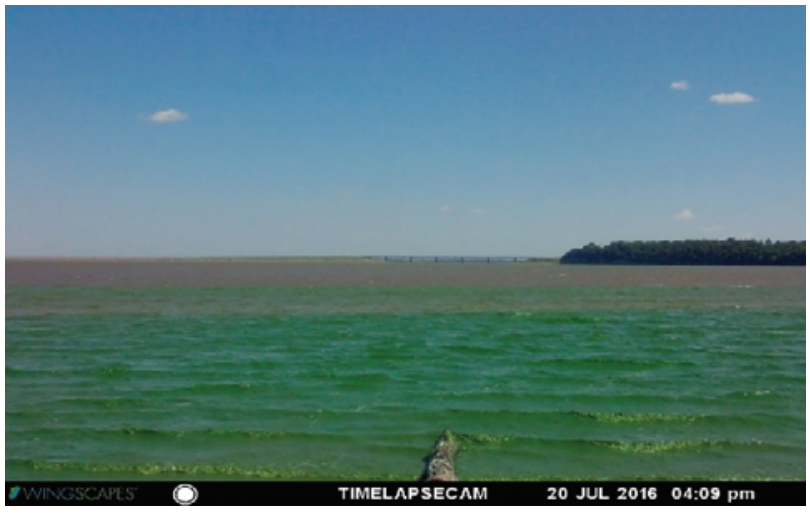

Figure 3. Cyanobacterial harmful algal bloom (CyanoHAB) variability in Milford Lake during July 2016. $A$ and $B$, CyanoHAB variability over the course of 1 hour on July 7, 2016, at the Timber Creek boat ramp camera; and $C$ and $D$, CyanoHAB variability over the course of 15 minutes on July 20, 2016, at the north camera. 
All sites had visual evidence of cyanobacterial blooms from early July until cameras were removed in late November. Based on camera images, the Timber Creek boat ramp and south causeway sites, near the causeway facing south to southwest (fig. 1), were the first to experience blooms (starting on July 2 and 3). The north causeway and Wakefield boat ramp sites, facing north to northeast towards open water (fig. 1), were the last to experience blooms (starting on July 4 and 5). Sites where camera imagery included visible shoreline (Timber Creek boat ramp, north, south, and south causeway) had larger accumulations and greater bloom visibility than sites with cameras facing open water (north causeway and Wakefield boat ramp); however, prevalent bloom accumulations were observed at all sites during July and August. Bloom accumulation at each site was dependent on wind direction. When wind came from the north, the south causeway and Wakefield boat ramp sites had larger nearshore accumulations. When the wind came from the south, the North and Timber Creek Boat Ramp sites had larger near-shore accumulations. After a change in wind direction, it would take about 1 day for accumulations to become visible at different locations. The south causeway camera captured the movement of blooms based on wind direction. Regardless of wind direction, once blooms appeared, the south causeway, north causeway, and Wakefield boat ramp sites always had visible cyanobacteria for the remainder of the monitored period. During periods with low wind, accumulations were widespread and visible at all sites.

\section{Seasonal Patterns at the Wakefield Site}

Discrete water-quality samples for the analysis of phytoplankton community composition and chlorophyll and microcystin concentrations were collected at the Wakefield site to broadly describe seasonal patterns during May through November 2016. Given the spatiotemporal variability of cyanobacteria in Milford Lake, discrete water-quality samples were not collected frequently enough to characterize algal community dynamics, and algal abundances and chlorophyll and microcystin concentrations do not necessarily reflect seasonal minima and maxima. A continuous water-quality monitor also was operated at the Wakefield site during May through November 2016. Continuously measured phycocyanin RFU was used to estimate chlorophyll and microcystin concentrations at the Wakefield site using the regression models developed with spatial data. Although the models were not developed specifically for the Wakefield site, the regression-estimated concentrations likely are more indicative of seasonal patterns in algal biomass (indicated by chlorophyll) and microcystin than discretely collected samples.

\section{Phytoplankton Community Composition}

Overall phytoplankton abundance at the Wakefield site was relatively low in May, increased to the observed maximum in early June, and was variable from late June through the end of November (fig. 4). Diatoms (Bacillariophyta) dominated (more than 50 percent of total phytoplankton abundance) the algal community in late May and early June. In late June, cryptophytes (Cryptophyta) dominated the algal community. Cyanobacteria (Cyanophyta) were absent from the algal community in late May and were a minor (less than 10 percent) component of the community in June; however, by mid-July the cyanobacteria were dominant and remained dominant until early November. During September and early November, cyanobacteria composed about 80 percent of the algal community. Cyanobacteria (47 percent) were still in Milford Lake at the Wakefield site in late November and codominated the algal community along with diatoms (46 percent) (fig. 4).

Cyanobacterial abundance at the Wakefield site increased from May through November, with an observed maximum in early November (fig. 5). Overall, cyanobacterial abundances in discrete samples were low (maximum 26, 951 cells $/ \mathrm{mL}$ ) and did not exceed KDHE guidance values for public-health protection. Given the extreme spatial and temporal variability observed for Milford Lake cyanobacteria in Zone C (Foster and others, 2017), cyanobacterial abundances reflect broad seasonal patterns and do not characterize the full range of abundances that likely were at the site. A total of four cyanobacterial taxa were identified at the Wakefield site: Aphanizomenon, Cylindrospermopsis, Dolichospermum (formerly Anabaena), and Microcystis (a known microcystin producer and the dominant bloomcausing genera in Milford Lake). With the exception of Cylindrospermopsis, all taxa were in most samples and dominated the cyanobacterial community at least once during May through November 2016. Cylindrospermopsis was only detected in one sample (September) and was a minor (less than 1 percent of cyanobacterial abundance) component of the community. Dolichospermum (formerly Anabaena; 52 percent) and Aphanizomenon (47 percent) codominated the cyanobacterial community in early June, and Microcystis was absent. By late June, Microcystis dominated and remained dominant through September. Microcystis (46 percent) and Aphanizomenon (46 percent) codominated in early November, and Aphanizomenon dominated in late November (though Microcystis was still present) (fig. 5). 


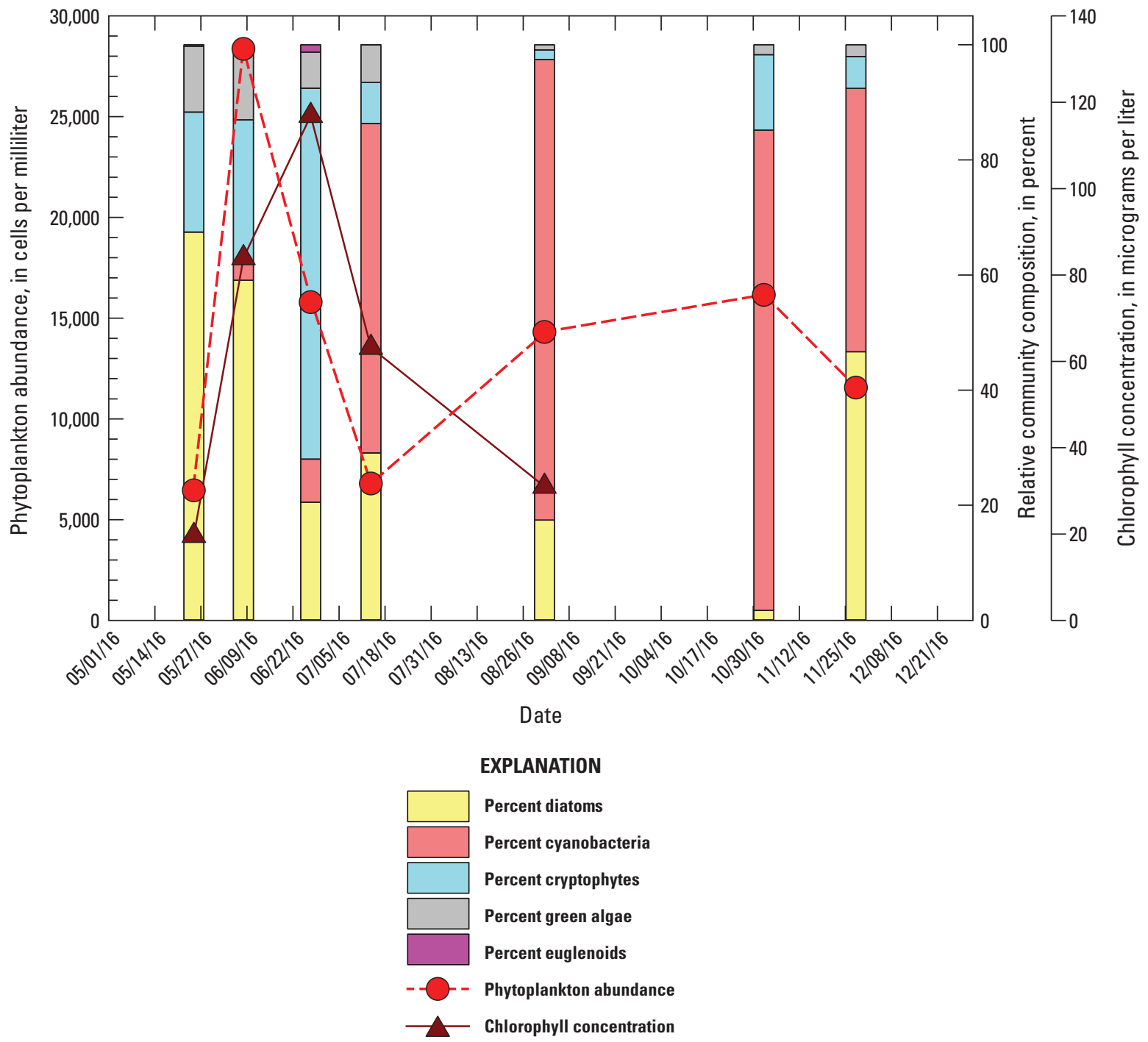

Figure 4. Phytoplankton abundance, community composition, and algal biomass (as indicated by chlorophyll concentration) at the Wakefield site at Milford Lake during May through November 2016. 


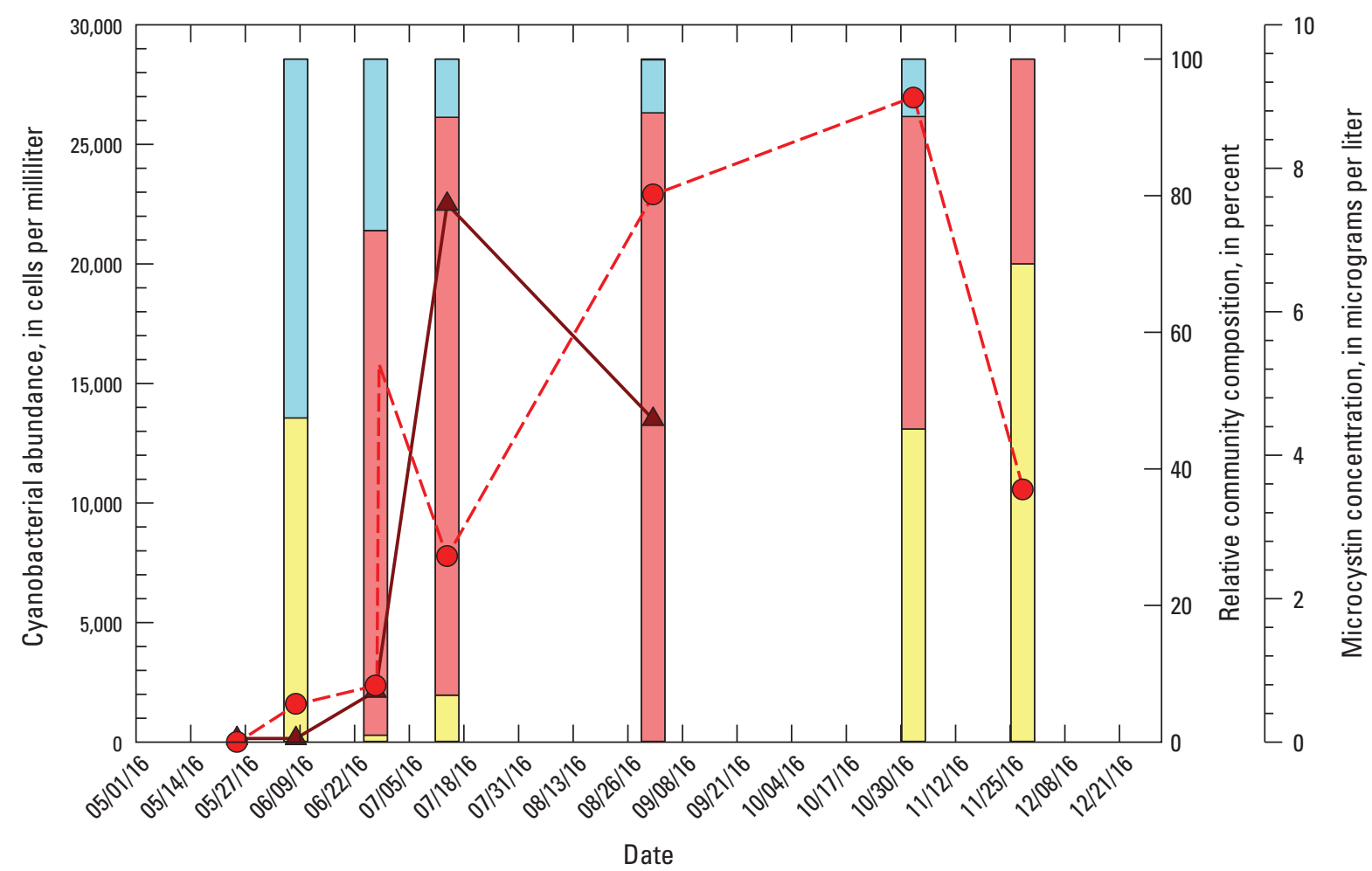

EXPLANATION

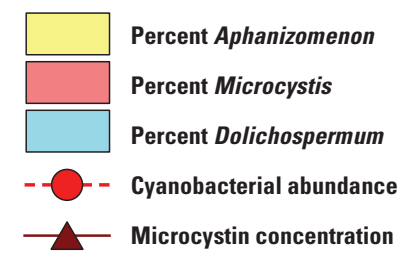

Figure 5. Cyanobacterial abundance, community composition, and microcystin concentration at the Wakefield site at Milford Lake during May through November 2016.

\section{Chlorophyll (Algal Biomass)}

Discrete chlorophyll samples at the Wakefield site were collected from late May through early September (fig. 4). Chlorophyll concentrations ranged from 19.6 to $116.9 \mu \mathrm{g} / \mathrm{L}$ (the median was $63.2 \mu \mathrm{g} / \mathrm{L}, n=5$ ). Based on chlorophyll concentrations, algal biomass was relatively low in May, increased to the observed maximum in late June, and then declined. The observed maximum in algal biomass was about 3 weeks after the observed maximum in phytoplankton abundance (fig. 4). Because regression-estimated chlorophyll concentrations were calculated every 15 minutes during May through November, these data likely are more indicative of seasonal patterns in algal biomass than the five discretely collected chlorophyll samples at the Wakefield site.

Regression-estimated chlorophyll concentrations at the Wakefield site ranged from 4.86 to $3,440 \mu \mathrm{g} / \mathrm{L}$, with a median regression-estimated concentration of $61.8 \mu \mathrm{g} / \mathrm{L}(n=14,432)$ (table 2). Although the regression-estimated chlorophyll concentrations spanned a wider range than the discretely collected samples, overall median concentrations were similar. Regression-estimated chlorophyll concentrations indicate different seasonal patterns in algal biomass than discretely collected samples because these data have a much higher temporal resolution and better capture seasonal dynamics. Based on regression-estimated chlorophyll concentrations, algal biomass at the Wakefield site steadily increased from May through August. Monthly median chlorophyll concentrations increased most rapidly between May and July; the median concentration in July was about 23 times higher than in May (table 2). After August, algal biomass decreased but remained relatively high compared to May and June. Monthly median chlorophyll concentrations in October and November were greater than in June and about six times higher than in May. 
Table 2. Summary statistics for regression-estimated chlorophyll and microcystin concentrations at the Wakefield site at Milford Lake during May through November 2016.

[ $n$, number of regression-estimated values; \pm , plus or minus; PI, 95-percent prediction interval (Neter and others, 1996); <, less than]

\begin{tabular}{|c|c|c|c|c|}
\hline Date & $n$ & Minimum \pm PI & Maximum $\pm \mathrm{PI}$ & Median \pm PI \\
\hline \multicolumn{5}{|c|}{ Chlorophyll, in micrograms per liter } \\
\hline May 25, 2016, to November 28, 2016 & 14,432 & $4.86( \pm 46)$ & $3,440( \pm 291)$ & $61.8( \pm 46)$ \\
\hline June 2016 & 1,497 & $4.86( \pm 46)$ & $920( \pm 86)$ & $33.9( \pm 46)$ \\
\hline July 2016 & 2,772 & $6.71( \pm 46)$ & $3,435( \pm 291)$ & $104( \pm 46)$ \\
\hline September 2016 & 2,780 & $18.8( \pm 46)$ & $879( \pm 83)$ & $96.4( \pm 46)$ \\
\hline October 2016 & 2,691 & $22.8( \pm 46)$ & $1,136( \pm 102)$ & $45.7( \pm 46)$ \\
\hline November 2016 & 2,592 & $23.4( \pm 46)$ & $1,028( \pm 94)$ & $59.6( \pm 46)$ \\
\hline June 2016 & 1,497 & $<0.07( \pm 19)$ & $249( \pm 36)$ & $2.82( \pm 19)$ \\
\hline July 2016 & 2,772 & $<0.07( \pm 19)$ & $948( \pm 123)$ & $22.2( \pm 19)$ \\
\hline August 2016 & 1,521 & $<0.07( \pm 19)$ & $843( \pm 109)$ & $55.1( \pm 20)$ \\
\hline September 2016 & 2,780 & $<0.07( \pm 19)$ & $238( \pm 35)$ & $20.2( \pm 19)$ \\
\hline October 2016 & 2,691 & $<0.07( \pm 19)$ & $309( \pm 43)$ & $6.09( \pm 19)$ \\
\hline November 2016 & 2,592 & $<0.07( \pm 19)$ & $279( \pm 40)$ & $9.96( \pm 19)$ \\
\hline
\end{tabular}

Although broad seasonal patterns in algal biomass were discernible, there was a substantial amount of variability at the Wakefield site (table 2). Daily chlorophyll maxima were as much as 400 times higher than daily minima (the median for the entire dataset was 3 times higher). Variability was highest during July and August compared to other months (table 2); the median differences between daily maxima and minima were 40 and 17 times higher (data not shown), respectively, when algal biomass also was high. The extreme variability in algal biomass at the Wakefield site reflects the movement, development, and dissipation of blooms, as indicated by the time-lapse photography (fig. 3).

\section{Microcystin}

Discrete microcystin samples at the Wakefield site were collected from late May through early September (fig. 5). Discrete microcystin concentrations ranged from less than 0.1 to $7.5 \mu \mathrm{g} / \mathrm{L}$ (the median was $0.71 \mu \mathrm{g} / \mathrm{L}, n=5$ ). Based on discrete samples, microcystin concentrations were relatively low in May and June, increased rapidly over a period of about 2 weeks to the observed maximum in mid-July, and then declined. The observed maximum in discrete microcystin concentrations was after observed maxima in phytoplankton abundance and algal biomass but before the observed maximum in cyanobacterial abundance (figs. 4 and 5).
Because regression-estimated microcystin concentrations were calculated every 15 minutes during May through November, these data likely are more indicative of seasonal patterns than the five discretely collected microcystin samples at the Wakefield site (samples collected on May 25, June 8, June 27, July 14, and September 1, 2016.

Regression-estimated microcystin concentrations at the Wakefield site ranged from less than $(<) 0.07$ to $948 \mu \mathrm{g} / \mathrm{L}$, with a median regression-estimated concentration of $10.6 \mu \mathrm{g} / \mathrm{L}(n=14,432)$ (table 2; fig. 6). Regressionestimated microcystin concentrations spanned a wider range than in discretely collected samples, and the regressionestimated median concentration was about 15 times higher than in discretely collected samples. Regression-estimated microcystin concentrations indicate similar seasonal patterns to discretely collected samples but better capture seasonal dynamics because of the higher temporal resolution. Like algal biomass, regression-estimated microcystin concentrations steadily increased from May through August. Monthly median regression-estimated microcystin concentrations increased most rapidly between May and July. Monthly median microcystin concentrations were below minimum reporting threshold for estimated values in May; the median concentration in July was about eight times higher than the median in June (table 2). After August, regression-estimated median microcystin concentrations decreased but remained higher than in May and June. 


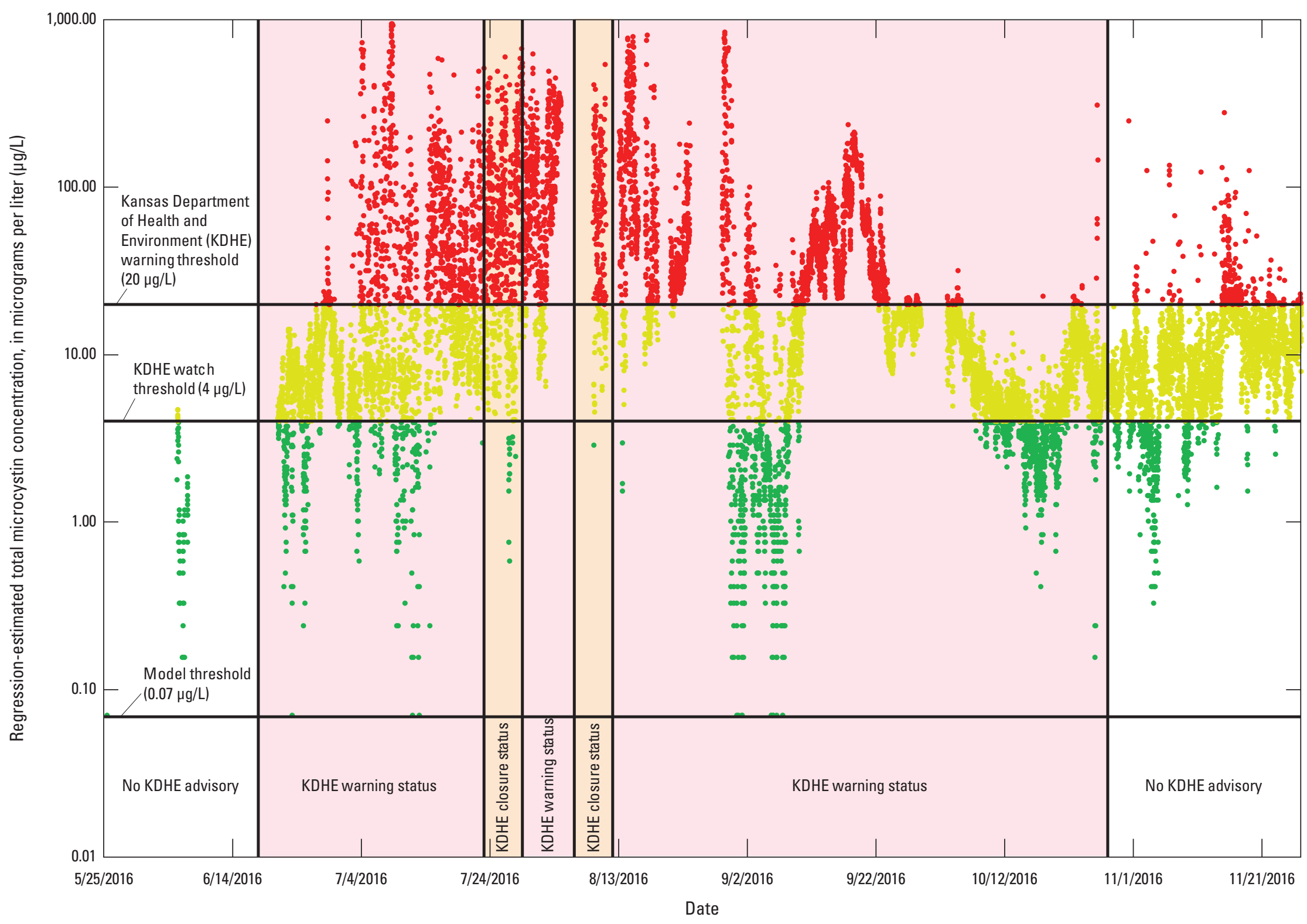

Figure 6. Regression-estimated microcystin concentrations at the Wakefield site at Milford Lake and Kansas Department of Health and Environment posted lake status during May through November 2016. 
As observed for algal biomass, there was a substantial amount of variability in regression-estimated microcystin concentrations at the Wakefield site (table 2; fig. 6). Daily regression-estimated microcystin maxima were as many as several orders of magnitude higher than daily minima (the median was nine times higher) (fig. 6). Variability in regression-estimated microcystin concentration also was highest during July and August compared to other months (table 2); the median differences between daily maxima and minima were 116 times higher and 20 times higher (data not shown), respectively. The extreme variability in regressionestimated microcystin concentrations reflects the variability in algal biomass caused by the development and dissipation of blooms.

Regression-estimated microcystin concentrations at the Wakefield site during May through November 2016 exceeded KDHE advisory thresholds about 79 percent of the time $(n=14,432)$. The watch threshold $(4 \mu \mathrm{g} / \mathrm{L})$ was exceeded about 48 percent of the time $(n=6,901)$ and the warning threshold $(20 \mu \mathrm{g} / \mathrm{L})$ was exceeded about 31 percent of the time $(n=4,485)$ (fig. 3$)$. Watch and warning thresholds for microcystin were exceeded during mid-June through late November. Based on regression-estimated microcystin concentrations, exceedance of KDHE advisory thresholds often changed from no advisory to watch and (or) warning over the course of a day because of the variability in algal biomass and microcystin concentrations caused by bloom development and dissipation (figs. 3, 6). However, during 2 weeks in August and 3 weeks in September, regressionestimated microcystin concentrations always exceeded watch or warning thresholds (fig. 6).

The KDHE approach to issue public-health advisories for CyanoHABs is to collect samples from near-shore access points, such as beaches and boat ramps, on Monday mornings and update lake advisory status when results are available, typically Thursday afternoons (Kansas Department of Health and Environment, 2015). Milford Lake was sampled by the KDHE for 19 weeks during 2016 (from the week of June 19 to the week of October 23). Weekly mean regression-estimated microcystin concentrations were calculated for the Wakefield site and used to determine advisory status based on KDHE thresholds (table 3 ). Regression-estimated advisory status at the Wakefield site was compared to KDHE advisories issued for Zone C in Milford Lake during summer 2016. Regressionestimated advisory status at the Wakefield site matched KDHE advisory status 47 percent (9 weeks) of the time. During the weeks that advisory status was not comparable, regressionestimated status was consistently one category lower than the actual KDHE advisory status (table 3 ). There were 8 weeks when a watch status was regression estimated, compared to the actual KDHE warning status. There were 2 weeks when a warning status was regression estimated, compared to the actual KDHE closure status. Though regression-estimated advisories at the Wakefield site tended to be lower than KDHE advisory status about one-half of the time, it is noteworthy that estimates were consistently lower by one category, rather than two or three.

Foster and others (2017) demonstrated that regardless of the individual agency's discrete sampling approach, the overall public-health advisory status in Milford Lake was similar according to the KDHE guidance levels, despite the observed variability in algal biomass and microcystin concentrations. However, the approaches used at the Wakefield site and by KDHE capture variability on different time scales (every 15 minutes and weekly, respectively), site types (open water and near shore), and analytical approaches (regression estimated and measured). The differences in approach (continuous regression estimates and discrete measured samples) likely caused some of the observed discrepancy in advisory status. Discrepancies also may have been caused by the time scale used for comparison (weekly means and a single point in time). For example, if weekly maxima in regressionestimated microcystin concentrations are used for comparison instead of weekly means, regression-estimated advisory status at the Wakefield site matched KDHE advisory status 89 percent (17 weeks) of the time. Results from this study indicate that continuous water-quality monitors may be useful in informing public-health decisions in lakes with variable CyanoHAB conditions; however, site-specific models need to be developed, and best practices for using continuous waterquality monitors to inform CyanoHAB management strategies need to be established. 
Table 3. Weekly comparison of sensor-measured phycocyanin and regression-estimated microcystin concentrations at the continuous water-quality monitor at Milford Lake near Wakefield, Kansas, and Kansas Department of Health and Environment lake status.

[n, number of samples; RFU, relative fluorescence unit; $\mu \mathrm{g} / \mathrm{L}$, microgram per liter; USGS, U.S. Geological Survey; KDHE, Kansas Department of Health and Environment; --, no data. Yellow highlighting indicates instances when regression-estimated lake status matched KDHE lake status]

\begin{tabular}{|c|c|c|c|c|c|c|c|c|c|c|}
\hline \multirow{2}{*}{ Week } & \multirow{2}{*}{ Dates } & \multicolumn{4}{|c|}{ Sensor measured phycocyanin (RFU) } & \multicolumn{3}{|c|}{ Regression-estimated microcystin ( $\mu \mathrm{g} / \mathrm{L}$ ) } & \multirow{2}{*}{$\begin{array}{l}\text { Lake status } \\
\text { according to USGS } \\
\text { continuous water- } \\
\text { quality monitor } \\
\text { (weekly mean) }\end{array}$} & \multirow{2}{*}{$\begin{array}{c}\text { KDHE lake } \\
\text { status }\end{array}$} \\
\hline & & $n$ & Minimum & Maximum & Mean & $\begin{array}{c}\text { Minimum } \\
\text { concentration }\end{array}$ & $\begin{array}{c}\text { Maximum } \\
\text { concentration }\end{array}$ & $\begin{array}{c}\text { Mean } \\
\text { concentration }\end{array}$ & & \\
\hline Week 1 & $5 / 22 / 2016-5 / 28 / 2016$ & 291 & 0.25 & 0.75 & 0.43 & 0.00 & 0.07 & 0.00 & No advisory & -- \\
\hline Week 2 & $5 / 29 / 2016-6 / 4 / 2016$ & 668 & 0.13 & 0.43 & 0.22 & 0.00 & 0.00 & 0.00 & No advisory & -- \\
\hline Week 3 & $6 / 5 / 2016-6 / 11 / 2016$ & 280 & 0.21 & 1.29 & 0.56 & 0.00 & 4.71 & 0.37 & No advisory & -- \\
\hline Week 4 & 6/12/2016-6/18/2016 & -- & -- & -- & -- & -- & -- & -- & -- & -- \\
\hline Week 5 & 6/19/2016-6/25/2016 & 380 & 0.66 & 2.40 & 1.40 & 0.00 & 14.3 & 5.64 & Watch & Warning \\
\hline Week 6 & $6 / 26 / 2016-7 / 2 / 2016$ & 553 & 0.78 & 29.7 & 2.10 & 0.33 & 249 & 11.7 & Watch & Warning \\
\hline Week 7 & $7 / 3 / 2016-7 / 9 / 2016$ & 666 & 0.19 & 111 & 9.12 & 0.00 & 948 & 72.0 & Warning & Warning \\
\hline Week 8 & $7 / 10 / 2016-7 / 16 / 2016$ & 571 & 0.20 & 69.5 & 5.22 & 0.00 & 591 & 38.5 & Warning & Warning \\
\hline Week 9 & $7 / 17 / 2016-7 / 23 / 2016$ & 671 & 1.09 & 68.2 & 6.02 & 2.99 & 580 & 45.4 & Warning & Warning \\
\hline Week 10 & $7 / 24 / 2016-7 / 30 / 2016$ & 672 & 0.81 & 79.5 & 11.5 & 0.59 & 677 & 92.3 & Warning & Closure \\
\hline Week 11 & 7/31/2016-8/6/2016 & 476 & 1.50 & 73.7 & 17.6 & 6.52 & 627 & 145 & Warning & Warning \\
\hline Week 12 & $8 / 7 / 2016-8 / 13 / 2016$ & 196 & 1.08 & 64.2 & 10.7 & 2.91 & 546 & 85.5 & Warning & Closure \\
\hline Week 13 & $8 / 14 / 2016-8 / 20 / 2016$ & 466 & 0.65 & 94.8 & 15.9 & 0.00 & 809 & 131 & Warning & Warning \\
\hline Week 14 & $8 / 21 / 2016-8 / 27 / 2016$ & 288 & 2.73 & 29.0 & 5.98 & 17.1 & 243 & 45.0 & Warning & Warning \\
\hline Week 15 & $8 / 28 / 2016-9 / 3 / 2016$ & 479 & 0.56 & 98.8 & 6.94 & 0.00 & 843 & 53.3 & Warning & Warning \\
\hline Week 16 & 9/4/2016-9/10/2016 & 672 & 0.61 & 6.39 & 1.42 & 0.00 & 48.6 & 5.85 & Watch & Warning \\
\hline Week 17 & 9/11/2016 - 9/17/2016 & 672 & 1.48 & 13.2 & 5.68 & 6.35 & 107 & 42.4 & Warning & Warning \\
\hline Week 18 & $9 / 18 / 2016-9 / 24 / 2016$ & 672 & 1.74 & 28.4 & 9.07 & 8.58 & 238 & 71.6 & Warning & Warning \\
\hline Week 19 & $9 / 25 / 2016-10 / 1 / 2016$ & 476 & 1.64 & 3.38 & 2.61 & 7.72 & 22.7 & 16.0 & Watch & Warning \\
\hline Week 20 & $10 / 2 / 2016-10 / 8 / 2016$ & 484 & 1.15 & 4.45 & 2.16 & 3.51 & 31.9 & 12.2 & Watch & Warning \\
\hline Week 21 & $10 / 9 / 2016-10 / 15 / 2016$ & 672 & 0.92 & 2.33 & 1.35 & 1.53 & 13.7 & 5.24 & Watch & Warning \\
\hline Week 22 & $10 / 16 / 2016-10 / 22 / 2016$ & 672 & 0.74 & 3.34 & 1.21 & 0.00 & 22.3 & 4.04 & Watch & Warning \\
\hline Week 23 & $10 / 23 / 2016-10 / 29 / 2016$ & 671 & 0.71 & 36.7 & 1.91 & 0.00 & 309 & 10.0 & Watch & Warning \\
\hline Week 24 & $10 / 30 / 2016-11 / 5 / 2016$ & 672 & 0.73 & 29.9 & 1.58 & 0.00 & 251 & 7.18 & Watch & -- \\
\hline Week 25 & $11 / 6 / 2016-11 / 12 / 2016$ & 672 & 0.89 & 16.5 & 1.89 & 1.27 & 135 & 9.85 & Watch & -- \\
\hline Week 26 & $11 / 13 / 2016-11 / 19 / 2016$ & 672 & 0.92 & 33.2 & 2.81 & 1.53 & 279 & 17.8 & Watch & -- \\
\hline Week 27 & $11 / 20 / 2016-11 / 26 / 2016$ & 672 & 1.04 & 6.74 & 2.19 & 2.56 & 51.6 & 12.5 & Watch & -- \\
\hline Week 28 & $11 / 27 / 2016-12 / 3 / 2016$ & 96 & 1.67 & 3.44 & 2.49 & 7.98 & 23.2 & 15.0 & Watch & -- \\
\hline
\end{tabular}




\section{Spatial and Temporal Variability}

Spatial data were collected on May 26, July 21, and September 15, 2016, using a combination of a boatmounted sensor array and discrete water-quality samples analyzed for phytoplankton community composition and microcystin and chlorophyll concentrations. A total of two consecutive spatial surveys following the same route throughout Zone $\mathrm{C}$ were completed to characterize changing conditions throughout the course of the day. Spatial patterns were described using regression-estimated chlorophyll and microcystin concentrations.

\section{Results for May 26, 2016}

Air temperatures averaged between 20.1 and 20.8 degrees Celsius $\left({ }^{\circ} \mathrm{C}\right)$ during May 25-26, 2016. Winds were generally from the south, southeast, and east, with average wind speeds between 2.45 and 2.93 meters per second $(\mathrm{m} / \mathrm{s})$. Average rainfall amounts at the three weather stations ranged from 121.0 to 175.2 millimeters $(\mathrm{mm})$, and rainfall was during daylight hours on May 25 and May 26, 2016.

The average lake elevation on May 26, 2016, was

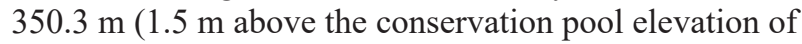
$348.8 \mathrm{~m}$ ). To assess lake conditions before spatial surveys, inflow, outflow, and lake storage data for the week before and day of survey (May 19-26, 2016) were analyzed. Inflows ranged from 716 to 14,237 cubic meters per second $\left(\mathrm{m}^{3} / \mathrm{s}\right)$ and averaged $3,263 \mathrm{~m}^{3} / \mathrm{s}$. A large inflow event began on May 24, 2016, and lasted until May 25, 2016 (maximum streamflow: $14,237 \mathrm{~m}^{3} / \mathrm{s}$ ). During May 19 through May 26, lake outflows ranged from 30.6 to $2,330 \mathrm{~m}^{3} / \mathrm{s}$ (the average was $1,231 \mathrm{~m}^{3} / \mathrm{s}$ ), lake storage ranged from 542 to $578 \mathrm{hm}^{3}$, and average water residence time (outflow $\left[\mathrm{m}^{3} / \mathrm{sec}\right]$ divided by reservoir storage $\left[\mathrm{m}^{3}\right]$ multiplied by a time conversion of 0.0000115741 [seconds to days]) was 1,343 days.

\section{Discrete Sample Results}

A total of eight discrete samples for phytoplankton community composition and chlorophyll and microcystin concentration analyses were collected throughout Zone C during the May spatial survey (fig. 7). Overall, phytoplankton abundances were low (the median was 20,562 cells $/ \mathrm{mL}$ ) throughout Zone $\mathrm{C}$ in May but varied depending on sample location (the range was from 2,900 to 43,200 cells $/ \mathrm{mL}$ ). In general, phytoplankton abundance decreased from north to south in Zone C. Phytoplankton abundance was about 5 to 15 times higher north of the causeway than in the transitional area between Zones C and B (fig. 7). Cyanobacterial abundances were low (the range was from 1,070 to 4,370 cells $/ \mathrm{mL}$ ) throughout Zone $\mathrm{C}$ and did not exceed $\mathrm{KDHE}$ guidance values.

The algal community in Zone $\mathrm{C}$ on May 26 was dominated by diatoms at most locations (the median was 71 percent; the range was from 13 to 80 percent). Cyanobacteria dominated or codominated (41 to 58 percent of total phytoplankton abundance) the algal community with diatoms at the three locations in the transitional area between Zones $\mathrm{C}$ and $\mathrm{B}$. The composition of the cyanobacterial community was variable throughout Zone C on May 26. A total of six cyanobacterial genera were represented (Aphanizomenon, Dolicospermum, Limnothrix, Microcystis, Planktolyngbya, and Pseudanabaena). Aphanizomenon (at 75 percent of sample locations) and Limnothrix (62 percent) were most common, and other taxa were in 12 to 38 percent of sample locations. On May 26, Microcystis was only in 25 percent of sample locations and only in the transitional area between Zones C and B (fig. 7).

Spatial patterns in algal biomass (as indicated by chlorophyll concentrations) matched patterns in phytoplankton abundance, with decreases from north to south. Overall, chlorophyll concentrations in Zone $\mathrm{C}$ ranged from 3.75 to $30.7 \mu \mathrm{g} / \mathrm{L}$ (the median was 26.7). Algal biomass was about five to eight times higher north of the causeway than in the transitional area between Zones C and B (fig. 7).

Discrete microcystin concentrations in Zone $\mathrm{C}$ ranged from $<0.10$ to $1.20 \mu \mathrm{g} / \mathrm{L}$ (the median was $0.24 \mu \mathrm{g} / \mathrm{L}$ ) and did not exceed KDHE guidance values. Spatial patterns in discrete microcystin did not match patterns in phytoplankton abundance or algal biomass. Discrete microcystin was not detected north of the causeway, where algal biomass was highest, but was consistently detected from the middle of Zone $\mathrm{C}$ into the transitional area between Zones $\mathrm{C}$ and $\mathrm{B}$ (fig. 7). In the transitional area between Zones $\mathrm{C}$ and $\mathrm{B}$, overall phytoplankton and cyanobacterial abundances were low, but cyanobacteria dominated the algal community at these locations and Microcystis was present.

\section{Spatial Survey Results}

Spatial surveys were completed on May 26, 2016, to capture prealgal bloom conditions in Zone C of Milford Lake, Kans. Because of safety concerns related to nearby storm activity, the second spatial survey was not fully completed, and the data above the causeway were not as spatially dense (figs. 8 and 9). Regression-estimated chlorophyll concentrations were used to describe the distribution of algal biomass at a $0.5-\mathrm{m}$ depth in Zone $\mathrm{C}$ of Milford Lake on May 26, 2016.

Regression-estimated chlorophyll concentrations at a $0.5-\mathrm{m}$ depth during the first spatial survey ranged from 1.77 to $24.3 \mu \mathrm{g} / \mathrm{L}(n=363)$ and varied by a factor of about 14 throughout Zone C. Regression-estimated chlorophyll concentrations at a $0.5-\mathrm{m}$ depth during the second spatial survey had a slightly larger range (from 1.46 to $33.0 \mu \mathrm{g} / \mathrm{L}$; $n=267$ ) and varied by a factor of about 23 throughout Zone C (fig. 8; table 4). Despite the larger range, the median concentration during the first spatial survey $(12.9 \mu \mathrm{g} / \mathrm{L})$ was about 1.6 times higher than the second spatial survey $(7.95 \mu \mathrm{g} / \mathrm{L})$, indicating that algal distribution in the water column may have changed between the two runs. 


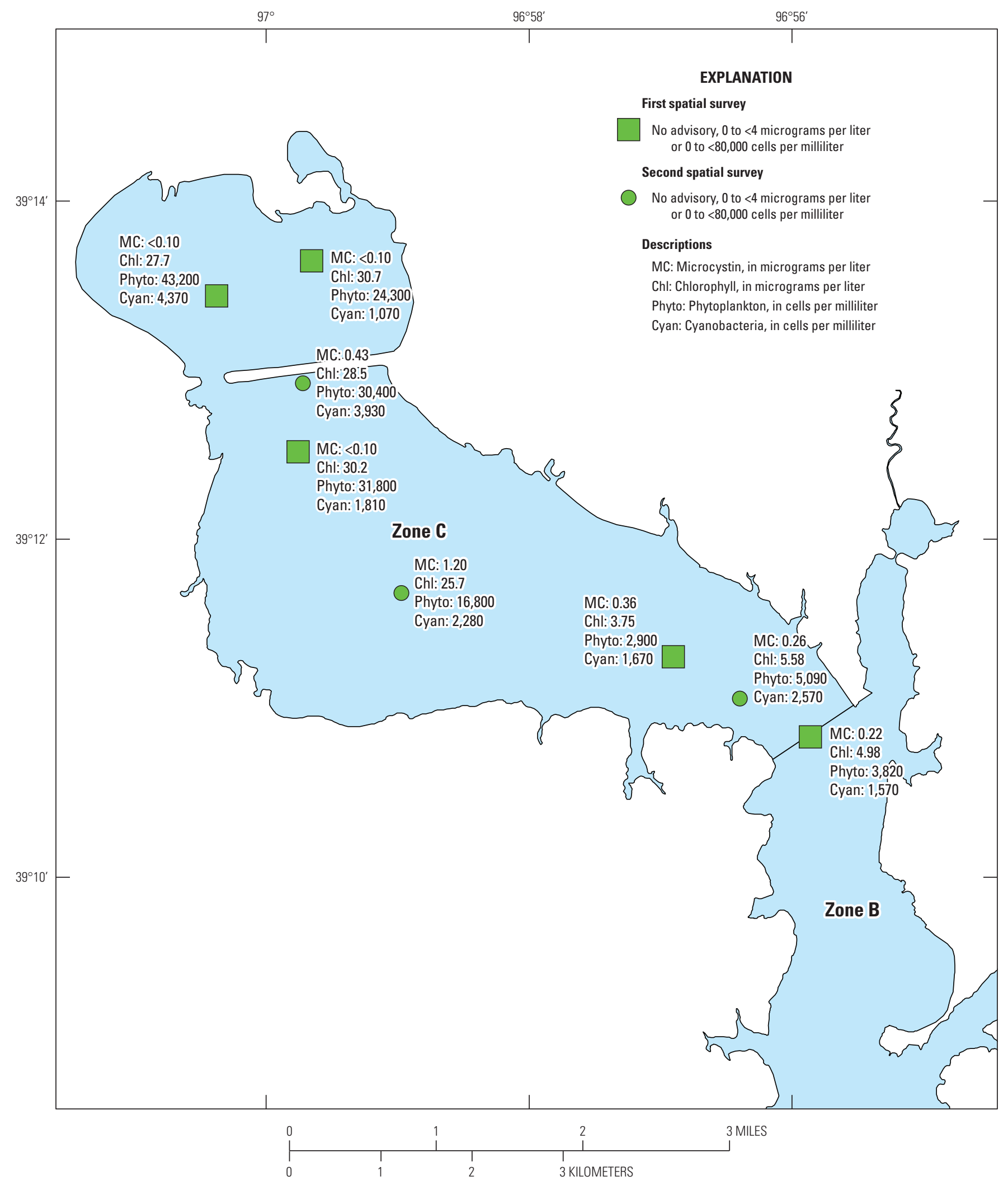

Figure 7. Discrete phytoplankton and cyanobacterial abundances and chlorophyll and microcystin concentrations in Zone $\mathrm{C}$ of Milford Lake on May 26, 2016. 

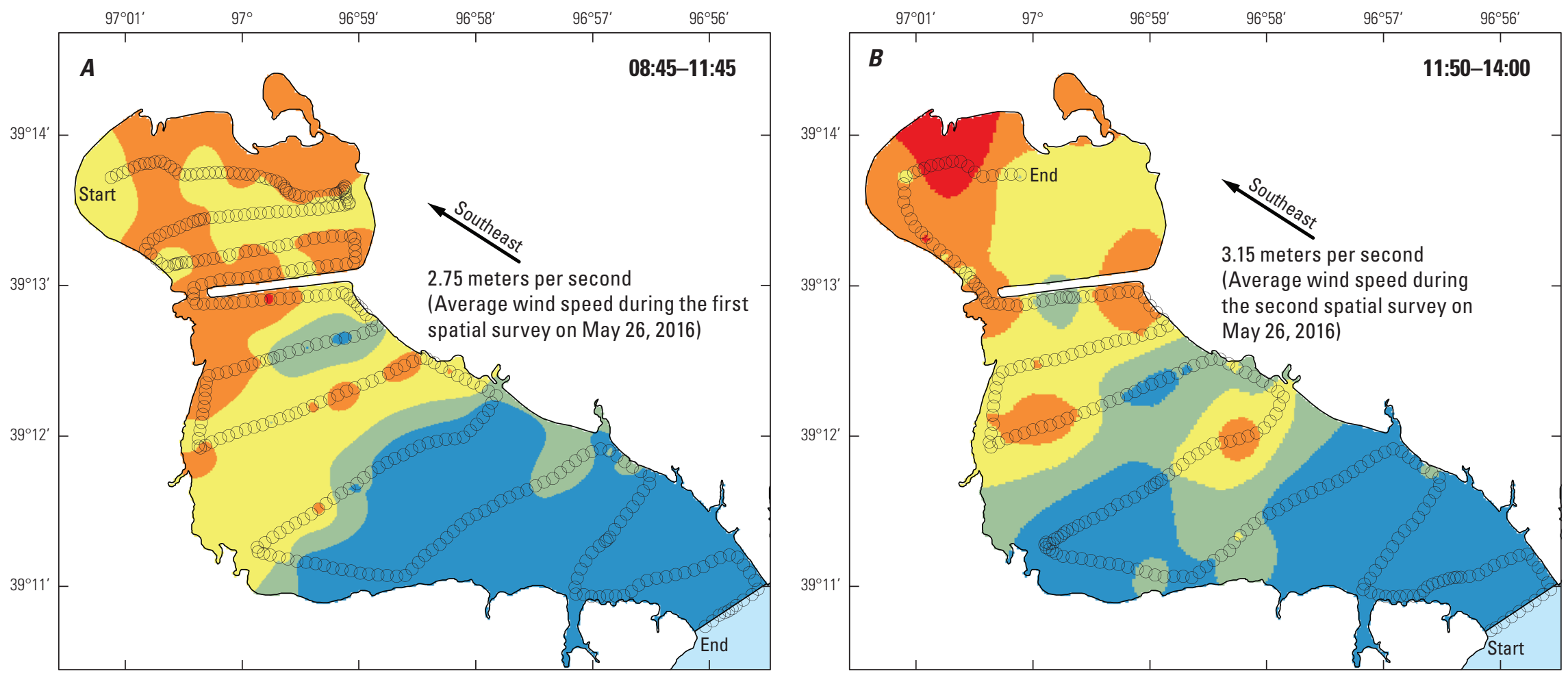

\section{EXPLANATION}

Regression-estimated chlorophyll,

in micrograms per liter
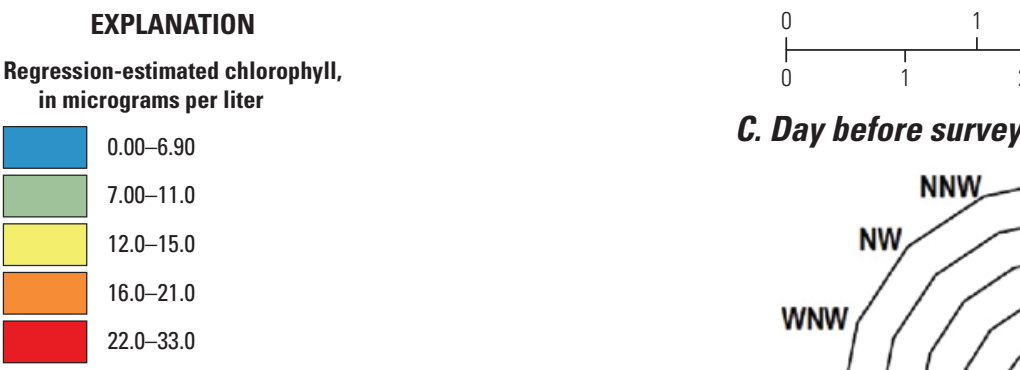

2

3 MILES

3 KILOMETERS

C. Day before survey N

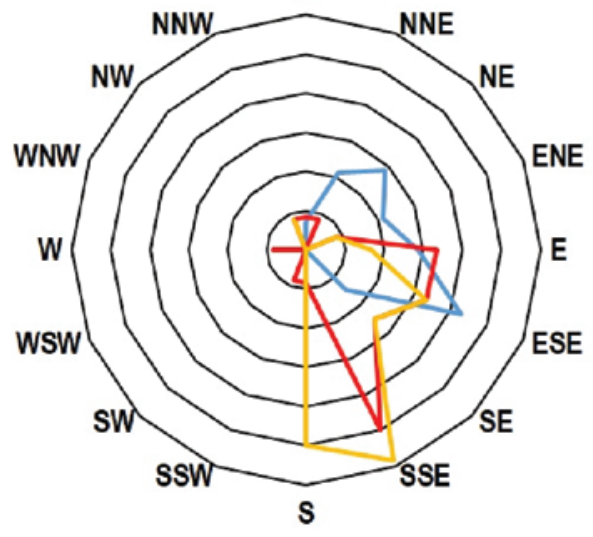

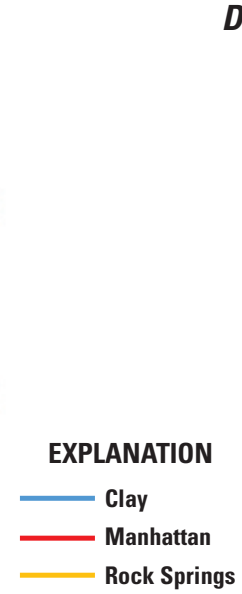

D. Day of survey

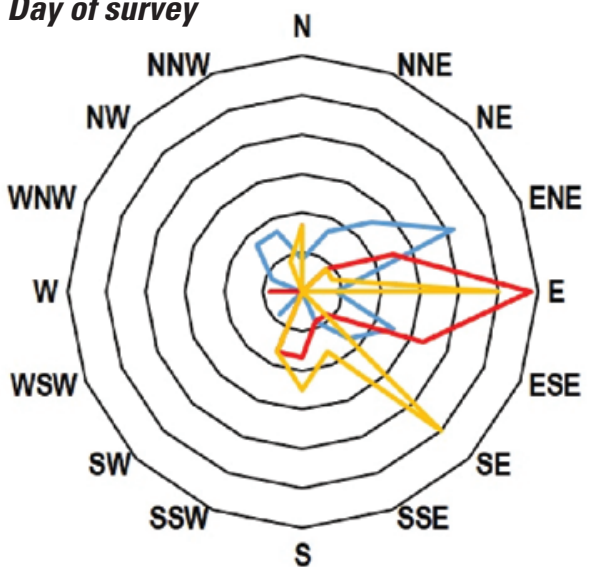

Wind rose diagrams represent the relative frequency the wind was coming from a certain direction.

Figure 8. Regression-estimated chlorophyll concentrations at a 0.5-meter depth in Zone $C$ of Milford Lake on May 26, 2016. $A$, first spatial survey; $B$, second spatial survey; $C$, wind rose diagram displaying relative frequency for hourly wind direction on May 25, 2016; and $D$, wind rose diagram displaying relative frequency for hourly wind direction on the day of the spatial survey, May 26, 2016. 


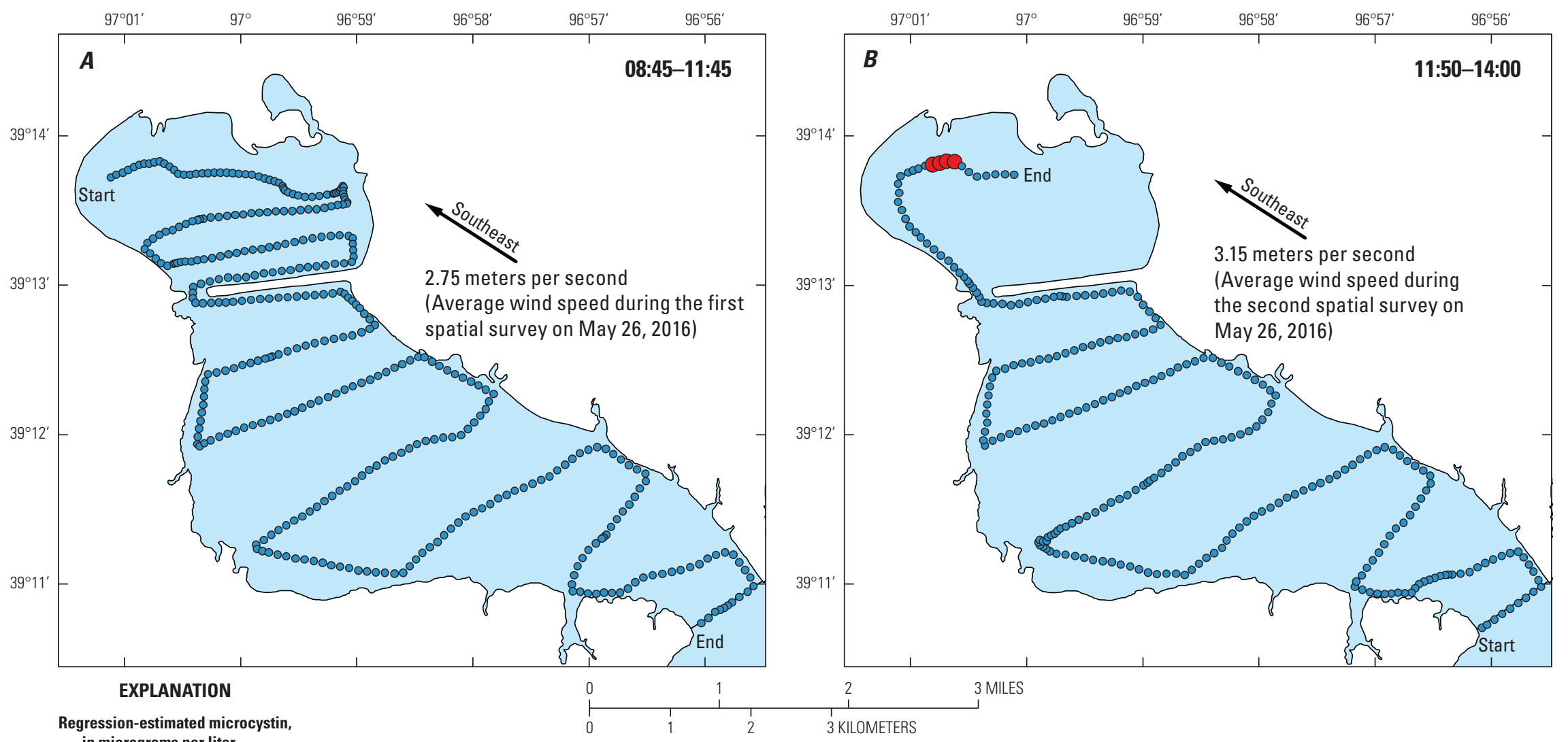
in micrograms per liter

○ $<0.07-1.00$

C. Day before survey

$1.01-3.00$
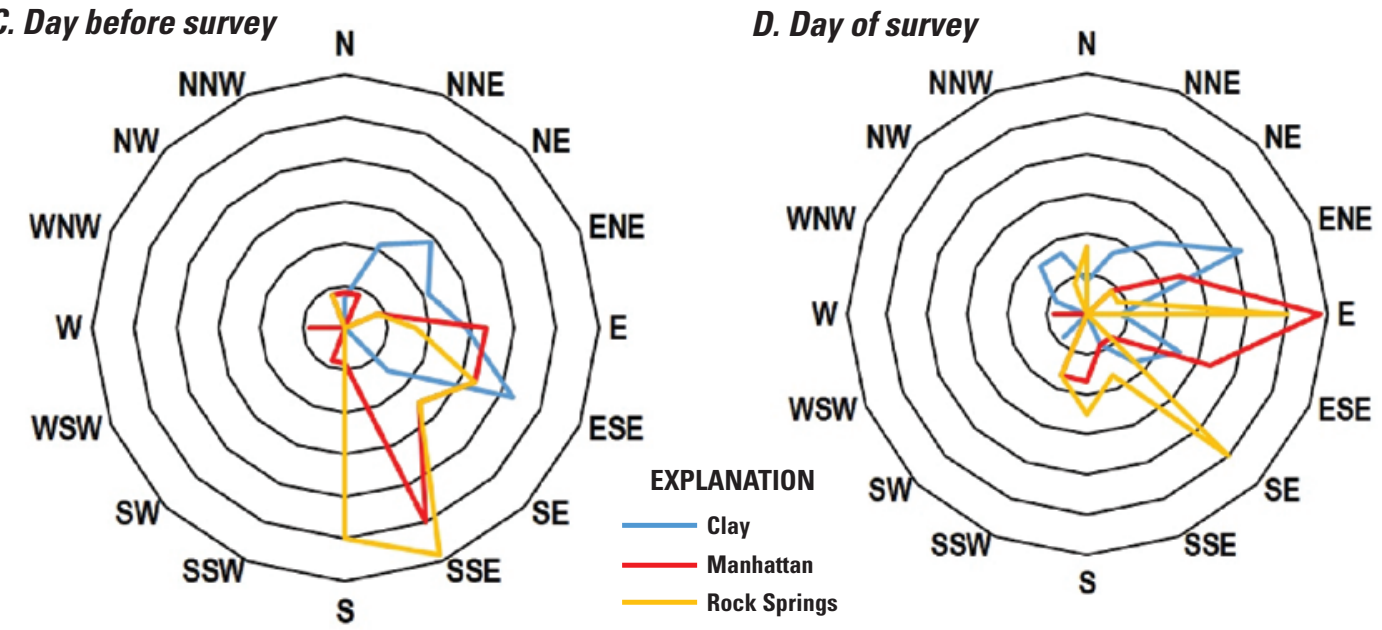

Wind rose diagrams represent the relative frequency the wind was coming from a certain direction.

Figure 9. Regression-estimated microcystin concentrations at a 0.5-meter depth in Zone $C$ of Milford Lake on May 26, 2016. $A$, first spatial survey; $B$, second spatial survey; $C$, wind rose diagram displaying relative frequency for hourly wind direction on May 25, 2016; and $D$, wind rose diagram displaying relative frequency for hourly wind direction on the day of the spatial survey, May 26, 2016. Model censored data at 0.07 micrograms per liter. 
Table 4. Summary statistics for regression-estimated chlorophyll and microcystin concentrations in Zone $\mathrm{C}$ of Milford Lake on May 26, 2016.

[ $n$, number of regression-estimated values; \pm , plus or minus; PI, 95-percent prediction interval (Neter and others, 1996); <, less than]

\begin{tabular}{ccccc}
\hline $\begin{array}{c}\text { Spatial } \\
\text { survey }\end{array}$ & $\boldsymbol{n}$ & $\begin{array}{c}\text { Minimum } \\
\mathbf{\pm} \mathbf{P I}\end{array}$ & $\begin{array}{c}\text { Maximum } \\
\mathbf{\pm} \mathbf{P I}\end{array}$ & $\begin{array}{c}\text { Median } \\
\mathbf{\pm P I}\end{array}$ \\
\hline \multicolumn{5}{c}{ Chlorophyll, in micrograms per liter } \\
\hline 1 & 363 & $1.77( \pm 46)$ & $24.3( \pm 46)$ & $12.9( \pm 46)$ \\
2 & 267 & $1.46( \pm 46)$ & $33.0( \pm 46)$ & $7.95( \pm 46)$ \\
\hline \multicolumn{5}{c}{ Total microcystin, in micrograms per liter } \\
\hline 1 & 363 & $<0.07( \pm 19)$ & $0.16( \pm 19)$ & $<0.07( \pm 19)$ \\
2 & 267 & $<0.07( \pm 19)$ & $2.56( \pm 19)$ & $<0.07( \pm 19)$ \\
\hline
\end{tabular}

Similar to the patterns observed in discrete data, regression-estimated chlorophyll concentrations were indicative of higher algal biomass uplake in Zone $\mathrm{C}$, with decreases in the downlake direction towards Zone B. Regression-estimated chlorophyll concentrations also were more variable uplake than downlake. Spatial maps indicated changes in algal distribution at a $0.5-\mathrm{m}$ depth between the two paired runs (fig. 8). Changes in distribution between the two spatial surveys may have been caused by algal movement horizontally or vertically in the water column.

Regression-estimated microcystin concentrations were used to describe the distribution of algal toxins at a 0.5-m depth in Zone C of Milford Lake on May 26, 2016. Regression-estimated microcystin concentrations at a $0.5-\mathrm{m}$ depth in Zone $\mathrm{C}$ during the first spatial survey ranged from $<0.07$ to $0.16 \mu \mathrm{g} / \mathrm{L}$, with a median regression-estimated concentration of $<0.07 \mu \mathrm{g} / \mathrm{L}(n=363)$. Regression-estimated microcystin concentration at a $0.5-\mathrm{m}$ depth in Zone $\mathrm{C}$ during the second spatial survey ranged from $<0.07$ to $2.56 \mu \mathrm{g} / \mathrm{L}$, with a median regression-estimated concentration of $<0.07 \mu \mathrm{g} / \mathrm{L}$ ( $n=267$ ) (fig. 9; table 4). Based on regression estimates, microcystin concentrations did not exceed KDHE guidance values anywhere in Zone $\mathrm{C}$. Though medians were the same, regression-estimated microcystin concentrations for the second survey had a much wider range $(2.56 \mu \mathrm{g} / \mathrm{L})$ than the first spatial survey $(0.16 \mu \mathrm{g} / \mathrm{L})$; however, overall variability in regression-estimated microcystin concentrations was small throughout Zone C on May 26, reflecting conditions before the cyanobacterial bloom in the lake.

As observed in discrete data, spatial patterns in regression-estimated microcystin throughout Zone $\mathrm{C}$ did not match patterns in regression-estimated chlorophyll concentrations (figs. 8 and 9), likely because the algal community was not dominated by cyanobacteria at most locations on May 26. In contrast to discrete samples (fig. 7), the highest regression-estimated microcystin concentrations were observed north of the causeway during the second survey (fig. 9). Differences between discrete and estimated microcystin distributions may have been caused by discrete sample location, changes in algal distribution, or error associated with regression estimation.

\section{Results for July 21, 2016}

Air temperatures averaged between 30.6 and $31.7^{\circ} \mathrm{C}$ during July $20-21,2016$. Winds were generally from the southeast to southwest, with average wind speeds between 3.15 and $3.50 \mathrm{~m} / \mathrm{s}$. There was no rainfall during this period.

The average lake elevation on July 21, 2016, was $349.0 \mathrm{~m}(0.2 \mathrm{~m}$ above the conservation pool elevation of $348.8 \mathrm{~m}$ ). To assess lake conditions before spatial surveys, inflow, outflow, and lake storage for the week before and day of the survey (July 14-21, 2016) were analyzed. Inflows ranged from 10.1 to $18.8 \mathrm{~m}^{3} / \mathrm{s}$ and averaged $14.0 \mathrm{~m}^{3} / \mathrm{s}$. There were no inflow events during that period, and discharge was decreasing throughout the week before the spatial survey. During July 14 through 21 , lake outflows ranged from 0.50 to $27.6 \mathrm{~m}^{3} / \mathrm{s}$ (average of $21 \mathrm{~m}^{3} / \mathrm{s}$ ), lake storage ranged from 475 to $482 \mathrm{hm}^{3}$, and average residence time was 1,064 days.

\section{Discrete Sample Results}

A total of 10 discrete samples for phytoplankton community composition and chlorophyll and microcystin concentration analyses were collected throughout Zone C during the July spatial survey (fig. 10). Overall, phytoplankton abundances were higher (the median was 92,796 cells $/ \mathrm{mL}$ ) throughout Zone C on July 21 than May 26 and varied substantially depending on sample location (the range was from 9,740 to $294,000,000$ cells $/ \mathrm{mL}$ ). Median cyanobacterial abundance on July $21(80,256$ cells/mL) was about 39 times higher than the median abundance on May 26 (2,044 cells $/ \mathrm{mL})$. Cyanobacterial abundances also varied substantially (the range was from 7,170 to $290,000,000$ cells $/ \mathrm{mL}$ ) throughout Zone C. In contrast to May 26, there were no clear patterns in phytoplankton or cyanobacterial abundances throughout Zone $\mathrm{C}$, though abundances did tend to be higher in the northern parts of the Zone (fig. 10). Cyanobacterial abundances exceeded KDHE guidance values in 50 percent of samples. The guidance value for watch status $(80,000$ cells $/ \mathrm{mL})$ was exceeded in 30 percent of samples, the guidance value for warning status $(250,000$ cells $/ \mathrm{mL})$ was exceeded in 10 percent of samples, and the guidance value for closure $(10,000,000$ cells $/ \mathrm{mL})$ was exceeded in 10 percent of samples.

The algal community in Zone C on July 21 was dominated by cyanobacteria at all locations (the median was 86 percent; the range was from 41 to 100 percent) except two, where cyanobacteria codominated with diatoms. Both locations where cyanobacteria and diatoms codominated were north of the causeway (fig. 10). The cyanobacterial community was dominated by Microcystis throughout Zone C on July 21 (the median was 98 percent of total cyanobacterial abundance; the range was from 46 to 100 percent). The only exception was observed at the transition between Zones $\mathrm{C}$ and B, where Microcystis (46 percent) and Dolichospermum (formerly Anabaena; 45 percent) codominated the cyanobacterial community. 


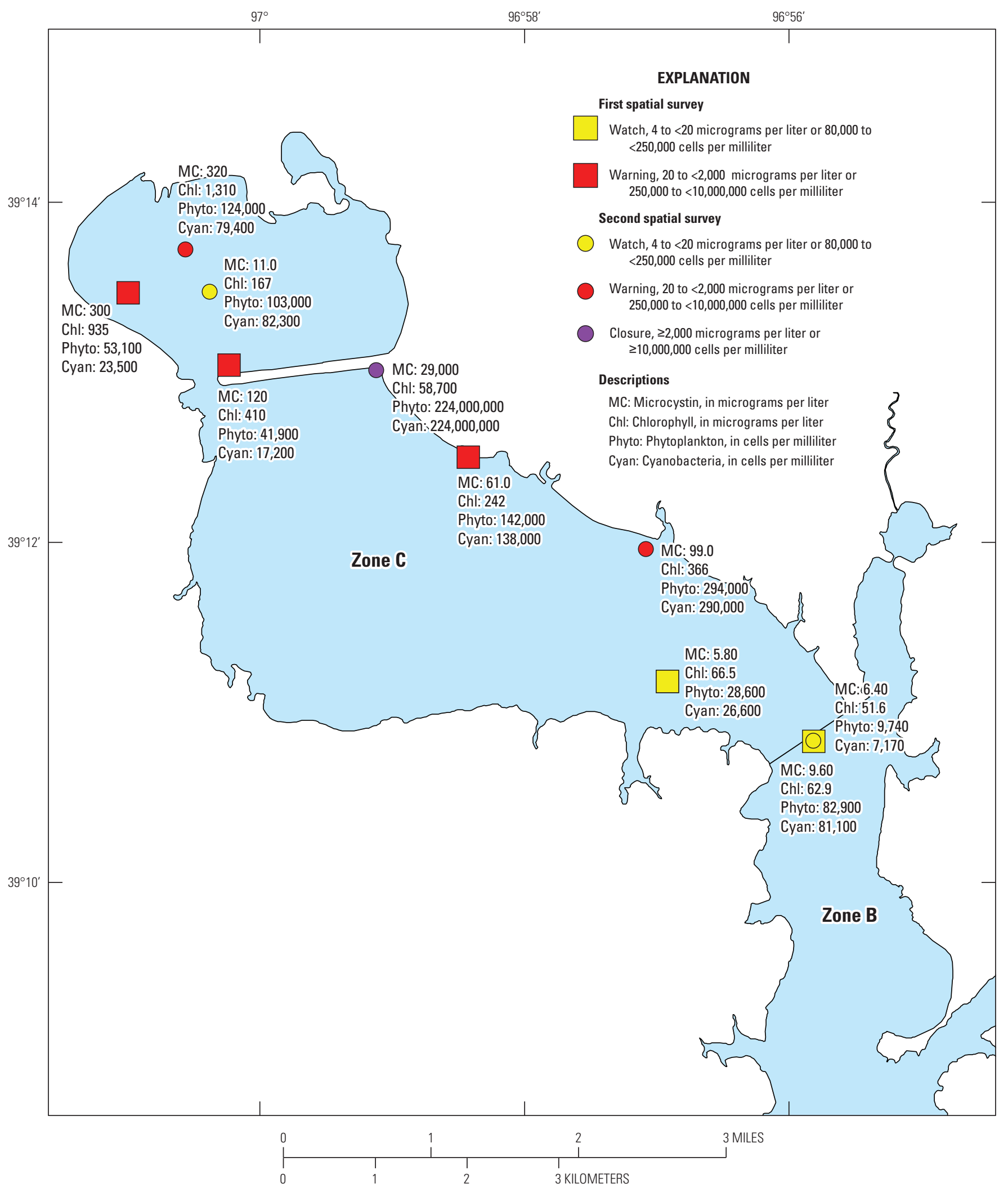

Figure 10. Discrete phytoplankton and cyanobacterial abundances and chlorophyll and microcystin concentrations in Zone $\mathrm{C}$ of Milford Lake on July 21, 2016. 
On July 21, chlorophyll concentrations in Zone C ranged from 51.6 to $58,700 \mu \mathrm{g} / \mathrm{L}$. The median chlorophyll concentration on July $21(304 \mu \mathrm{g} / \mathrm{L})$ was about 11 times higher than the median concentration on May $26(26.7 \mu \mathrm{g} / \mathrm{L})$. Spatial patterns in algal biomass (as indicated by chlorophyll concentrations) did not match overall patterns in phytoplankton abundance on July 21. Patterns were more similar to those observed on May 26, with higher biomass in the northern part of the zone and lower biomass in the transitional area between Zones C and B (figs. 7 and 10).

Discrete microcystin concentrations in Zone $\mathrm{C}$ varied substantially on July 21 , ranging from 5.8 to $29,000 \mu \mathrm{g} / \mathrm{L}$ (the median was $80 \mu \mathrm{g} / \mathrm{L}$ ). Discrete microcystin concentrations exceeded KDHE guidance values in all samples collected on July 21 . The guidance value for watch status $(4 \mu \mathrm{g} / \mathrm{L})$ was exceeded in 40 percent of samples, the guidance value for warning status $(20 \mu \mathrm{g} / \mathrm{L})$ was exceeded in 60 percent of samples, and the guidance value for closure $(20,000 \mu \mathrm{g} / \mathrm{L})$ was exceeded in 10 percent of samples. Spatial patterns in discrete microcystin more closely matched algal biomass than phytoplankton abundance. Though discrete microcystin concentrations were variable throughout Zone C, concentrations were lowest in the transitional area between Zones $\mathrm{C}$ and $\mathrm{B}$, similar to the pattern observed in algal biomass (fig. 10).

\section{Spatial Survey Results}

Regression-estimated chlorophyll concentrations were used to describe the distribution of algal biomass at a 0.5-m depth in Zone C of Milford Lake on July 21, 2016. Regression-estimated chlorophyll concentrations during the first spatial survey ranged from 18.5 to $679 \mu \mathrm{g} / \mathrm{L}(n=390)$ and varied by a factor of about 37 throughout Zone C. Regression-estimated chlorophyll concentrations during the second spatial survey were lower than the first, ranging from 15.1 to $551 \mu \mathrm{g} / \mathrm{L}(n=337)$, though variability between runs was similar (a factor of about 36) (fig. 11; table 5). The median concentration during the first spatial survey $(84.2 \mu \mathrm{g} / \mathrm{L})$ was about 1.2 times higher than the second spatial survey $(68.0 \mu \mathrm{g} / \mathrm{L})$. Median regression-estimated chlorophyll concentrations on July 21 were about 5 to 10 times higher than observed on May 26 (tables 4 and 5).

Spatial patterns in regression-estimated chlorophyll concentrations were similar to those observed in discrete samples, with a higher level of resolution (figs. 10 and 11). Regression-estimated chlorophyll concentrations were indicative of higher algal biomass north of the causeway and on the east shore of Zone C. On July 21, algal biomass did not necessarily decrease in the downlake direction. There was a decrease just south of the causeway but an increase shortly after with higher concentrations into Zone B. Spatial maps indicated changes in algal distribution at a $0.5-\mathrm{m}$ depth between the two paired runs, with algae moving to the central part of the lake north of the causeway and along the eastern shore south of the causeway (fig. 11).

Regression-estimated microcystin concentrations were used to describe the distribution of algal toxins at a 0.5-m depth in Zone C of Milford Lake on July 21, 2016. Regression-estimated microcystin concentrations in Zone $\mathrm{C}$ during the first spatial survey ranged from $<0.07$ to $182 \mu \mathrm{g} / \mathrm{L}$, with a median regression-estimated concentration of $16.8 \mu \mathrm{g} / \mathrm{L}$ $(n=390)$. Regression-estimated microcystin concentrations in Zone $\mathrm{C}$ during the second spatial survey ranged from $<0.07$ to $147 \mu \mathrm{g} / \mathrm{L}$, with a median regression-estimated concentration of $12.3 \mu \mathrm{g} / \mathrm{L}$ ( $n=337$ ) (table 5; fig. 12). Overall differences in median and maximum concentrations between the two spatial surveys were small. The median and maximum concentrations during the first spatial survey were about 1.4 and 1.2 times higher, respectively, than the second spatial survey. The maximum discrete microcystin concentration was about 159 times higher than the maximum regression-estimated concentration during the spatial surveys. This likely was caused by a dense surface accumulation in the area where the discrete sample was collected. Median regression-estimated concentrations increased substantially between May 26 and July 21 , from $<0.07 \mu \mathrm{g} / \mathrm{L}$ to between 12.3 and $16.8 \mu \mathrm{g} / \mathrm{L}$ (tables 4 and 5).

Most regression-estimated microcystin concentrations on July 21 exceeded KDHE guidance values, reflecting the pervasive bloom conditions in Zone $\mathrm{C}$ during this period. During the first spatial survey, 41 percent of regressionestimated microcystin concentrations exceeded the guidance value for watch status $(4 \mu \mathrm{g} / \mathrm{L})$ and 43 percent exceeded the guidance value for warning status $(20 \mu \mathrm{g} / \mathrm{L})$. By comparison, during the second spatial survey, 49 percent of regressionestimated microcystin concentrations exceeded the guidance value for watch status and 33 percent exceeded the guidance value for warning status, reflecting the changing conditions in Zone $\mathrm{C}$ throughout the day.

Table 5. Summary statistics for regression-estimated chlorophyll and microcystin concentrations in Zone $\mathrm{C}$ of Milford Lake on July 21, 2016.

[ $n$, number of regression-estimated values; \pm , plus or minus; PI, 95-percent prediction interval (Neter and others, 1996); <, less than]

\begin{tabular}{ccccc}
\hline $\begin{array}{c}\text { Spatial } \\
\text { survey }\end{array}$ & $\boldsymbol{n}$ & $\begin{array}{c}\text { Minimum } \\
\mathbf{\pm} \mathbf{P I}\end{array}$ & $\begin{array}{c}\text { Maximum } \\
\mathbf{\pm P I}\end{array}$ & $\begin{array}{c}\text { Median } \\
\mathbf{\pm} \text { PI }\end{array}$ \\
\hline \multicolumn{5}{c}{ Chlorophyll, in micrograms per liter } \\
\hline 1 & 390 & $18.5( \pm 46)$ & $679( \pm 70)$ & $84.2( \pm 46)$ \\
2 & 337 & $15.1( \pm 46)$ & $551( \pm 62)$ & $68.0( \pm 46)$ \\
\hline \multicolumn{5}{c}{ Total microcystin, in micrograms per liter } \\
\hline 1 & 390 & $<0.07( \pm 19)$ & $182( \pm 29)$ & $16.8( \pm 19)$ \\
2 & 337 & $<0.07( \pm 19)$ & $147( \pm 26)$ & $12.3( \pm 19)$ \\
\hline
\end{tabular}




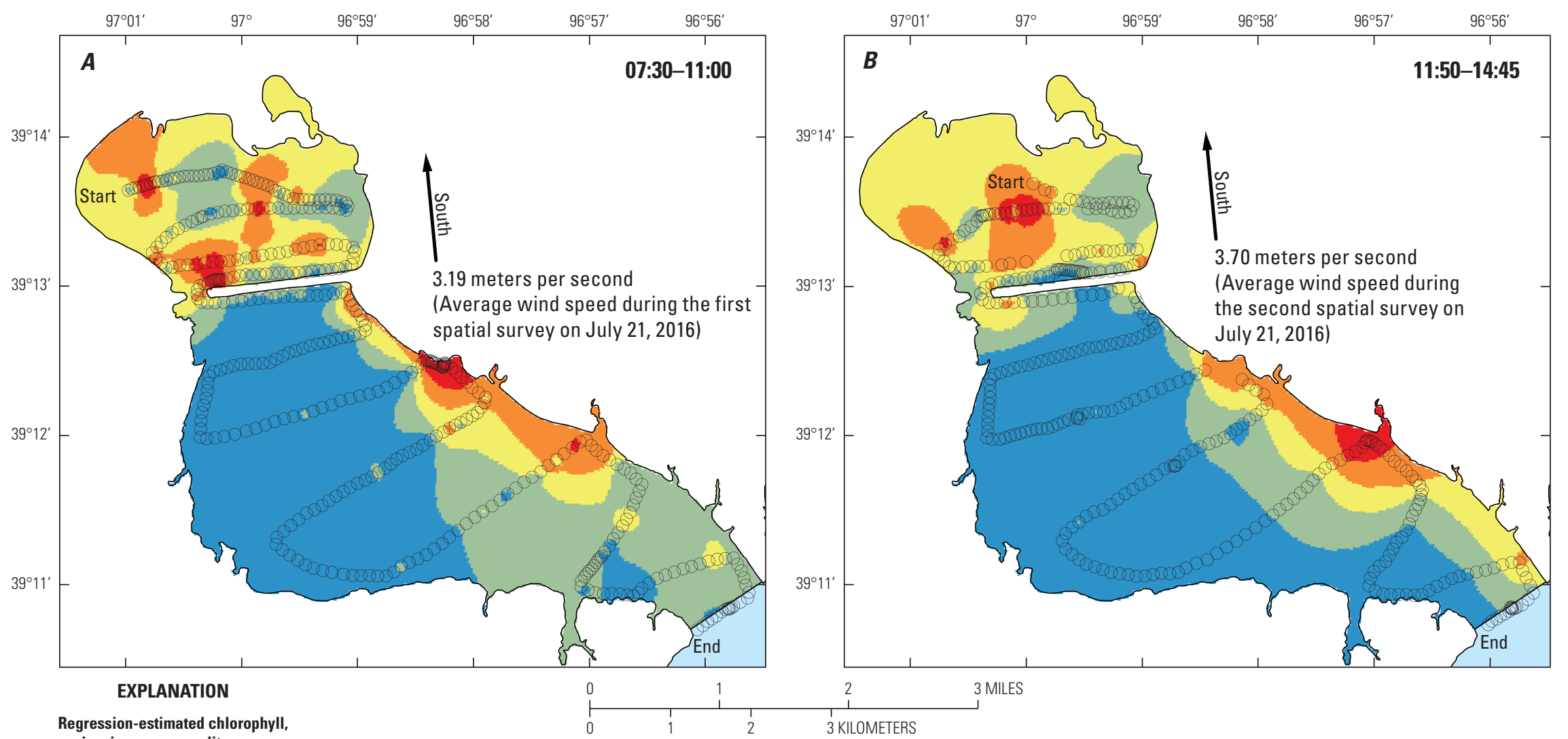

\begin{tabular}{|c|}
\hline $0.00-67.0$ \\
\hline $68.0-120$ \\
\hline $130-190$ \\
\hline $200-300$ \\
\hline $310-630$ \\
\hline
\end{tabular}
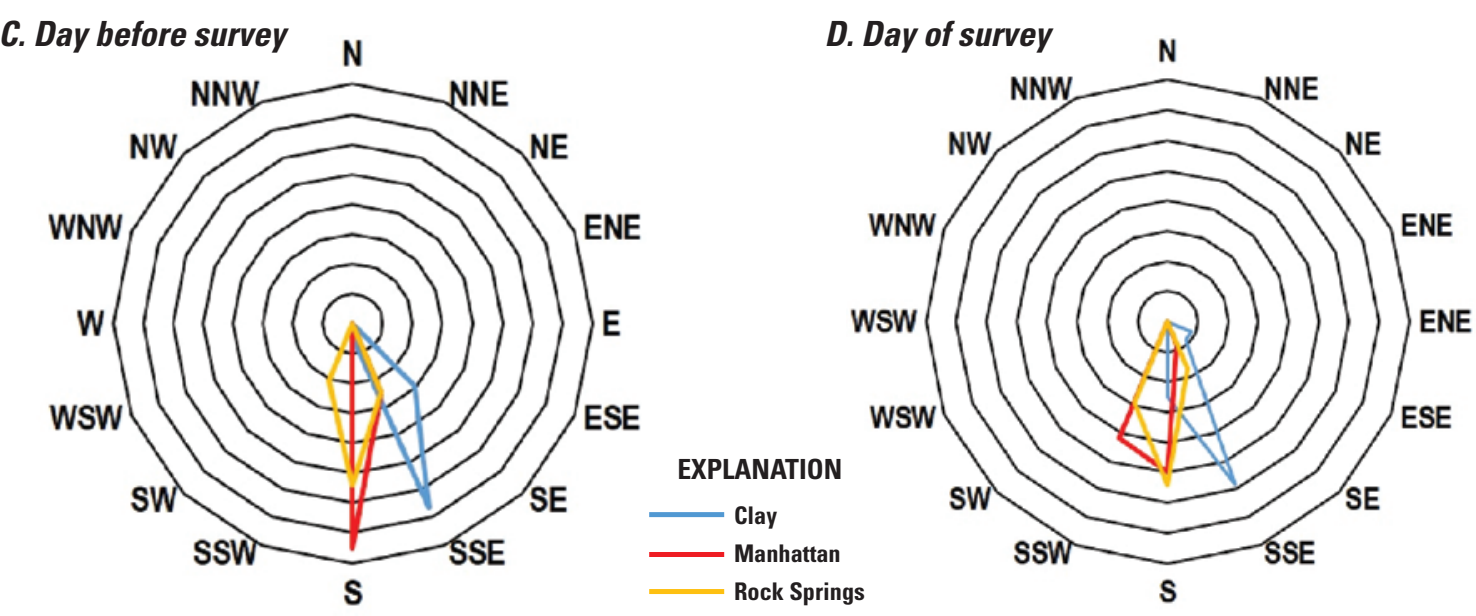

Wind rose diagrams represent the relative frequency the wind was coming from a certain direction.

Figure 11. Regression-estimated chlorophyll concentrations at a 0.5-meter depth in Zone C of Milford Lake on July 21, 2016. $A$, first spatial survey; $B$, second spatial survey; $C$, wind rose diagram displaying relative frequency for hourly wind direction on July 20, 2016; and $D$, wind rose diagram displaying relative frequency for hourly wind direction on the day of the spatial survey, July 21, 2016. 


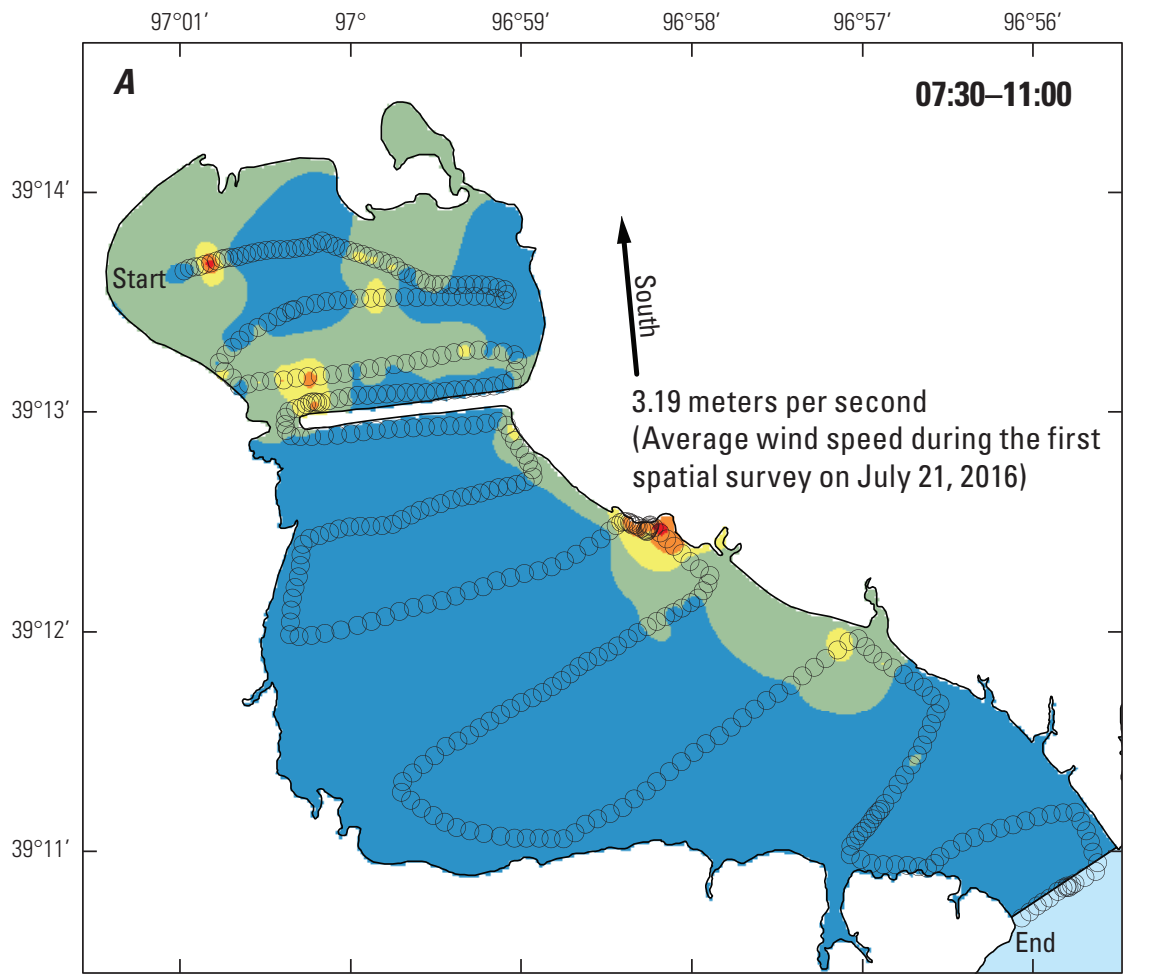

EXPLANATION

Regression-estimated total microcystin, in micrograms per liter

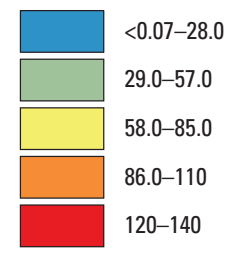

Boat path

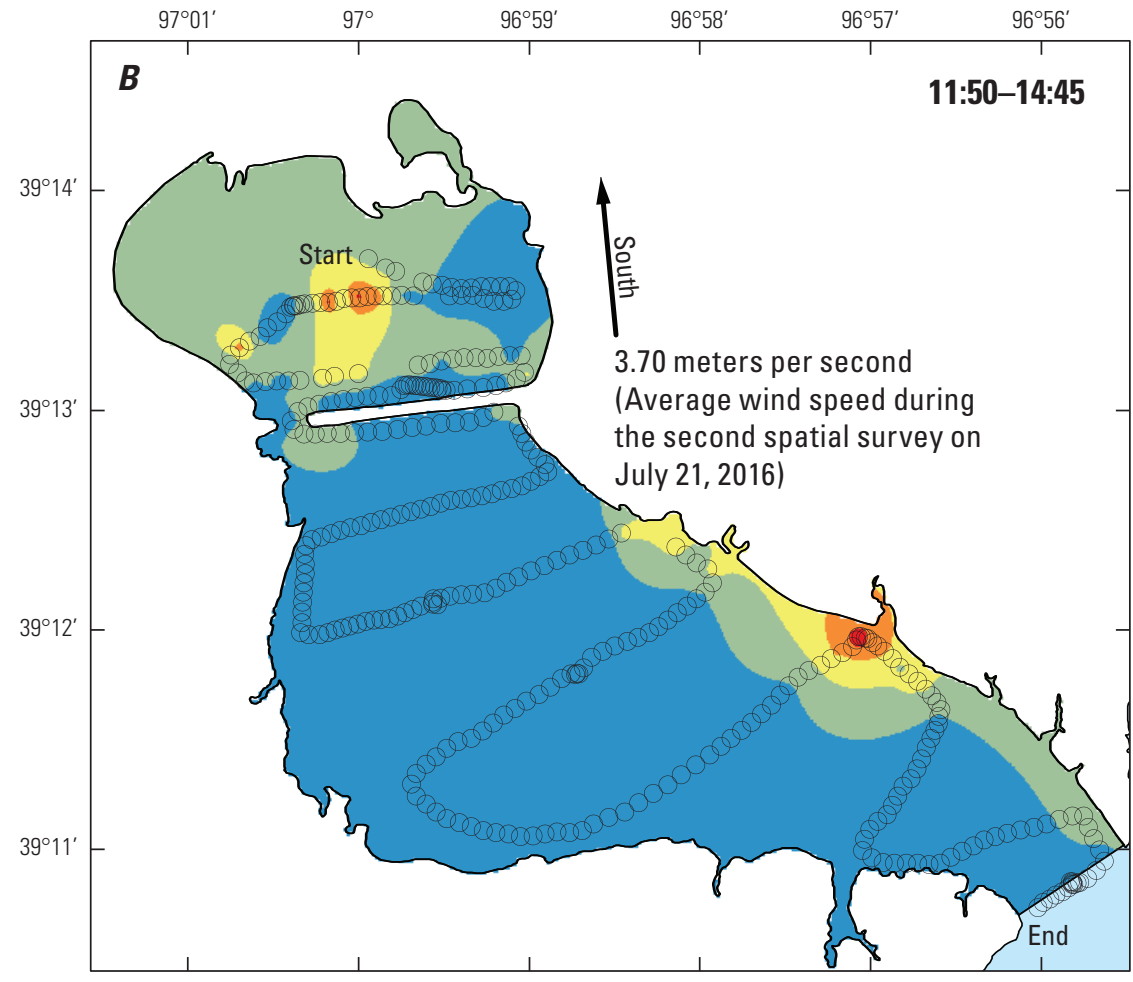

3 MILES

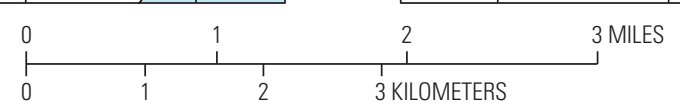

C. Day before survey

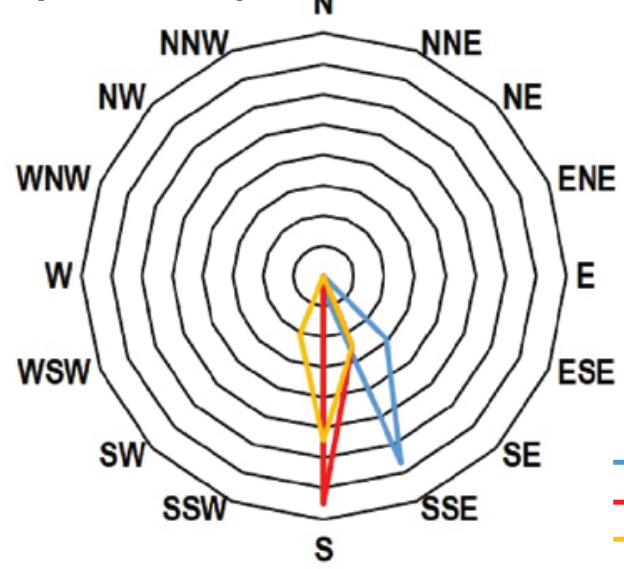

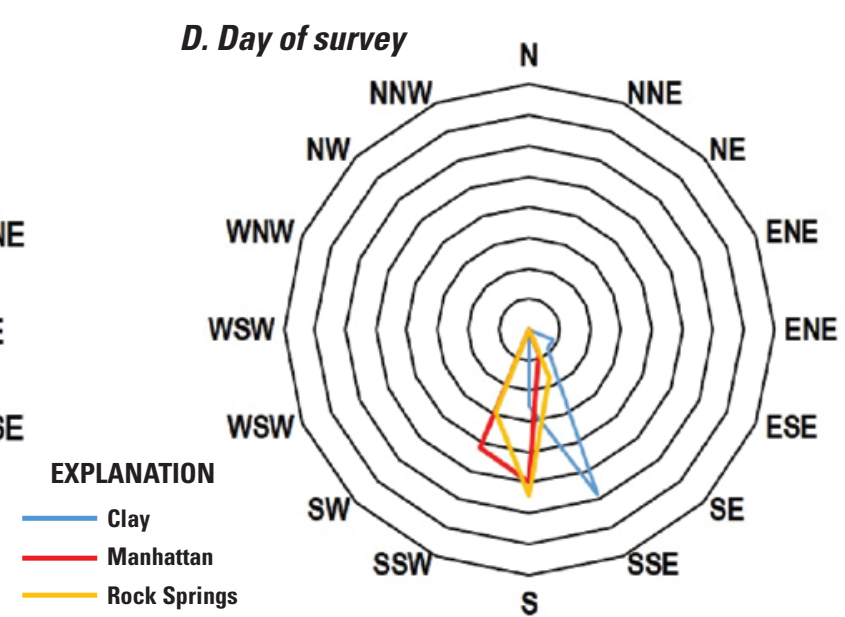

S

Wind rose diagrams represent the relative frequency the wind was coming from a certain direction

Figure 12. Regression-estimated microcystin concentrations at a 0.5-meter depth in Zone C of Milford Lake on July 21, 2016. $A$, first spatial survey; $B$, second spatial survey; $C$, wind rose diagram displaying relative frequency for hourly wind direction on July 20, 2016; and $D$, wind rose diagram displaying relative frequency for hourly wind direction on the day of the spatial survey, July 21,2016 . Model censored data at 0.07 micrograms per liter. 
Patterns between spatial surveys throughout Zone C were similar to patterns seen in discrete samples and regression-estimated chlorophyll concentrations, with higher concentrations of regression-estimated microcystin north of the causeway and on the east shore of Zone C. High regression-estimated microcystin concentrations were localized to a few areas upstream from the causeway and one area on the east shore of Zone $\mathrm{C}$ close to the boundary with Zone B. Spatial maps indicate changes in regression-estimated microcystin distribution similar to those observed for algal biomass at a $0.5-\mathrm{m}$ depth between the two paired runs (figs. 11 and 12).

\section{Results for September 15, 2016}

Air temperatures averaged between 19.8 and $21.0^{\circ} \mathrm{C}$ during September 14-15, 2016. Winds were generally from the north to northwest until late on September 14, 2016, when the wind direction shifted from the southeast to the southwest. Average wind speeds were between 1.48 and $2.02 \mathrm{~m} / \mathrm{s}$. There was light precipitation, ranging from 9 to $34 \mathrm{~mm}$ during September 14-15, 2016.

The average lake elevation on September 15, 2016, was $350 \mathrm{~m}$ (1.2 $\mathrm{m}$ above the conservation pool elevation of $348.8 \mathrm{~m}$ ). To assess lake conditions before the spatial surveys, inflow, outflow, and lake storage for the week before and day of survey (September 8-15, 2016) were analyzed. Inflows ranged from 12.6 to $35.9 \mathrm{~m}^{3} / \mathrm{s}$ and averaged $18.4 \mathrm{~m}^{3} / \mathrm{s}$. An inflow event peaked at $35.9 \mathrm{~m}^{3} / \mathrm{s}$ on September 14, 2016, and then decreased on September 15, 2016. During September 8 through 15, lake outflows ranged from 408 to $510 \mathrm{~m}^{3} / \mathrm{s}$ (average of $422 \mathrm{~m}^{3} / \mathrm{s}$ ), lake storage ranged from 510 to $520 \mathrm{hm}^{3}$, and average residence time was 498 days.

\section{Discrete Sample Results}

A total of 10 discrete samples for phytoplankton community composition and chlorophyll and microcystin concentration analyses were collected throughout Zone $\mathrm{C}$ during the September spatial survey (fig. 13). Overall, phytoplankton abundances on September 15 (median: 26,300 cells $/ \mathrm{mL}$ ) were lower than on July 21 and similar to those observed on May 26 (figs. 7, 10, and 13). As observed on May 26 and July 21, phytoplankton abundances varied substantially among sites on September 15 (the range was from 5,840 to 55,300 cells $/ \mathrm{mL}$ ). Median cyanobacterial abundance on September 15 (21,636 cells/mL) was about 3.6 times lower than median abundance on July 21 $(80,256$ cells/mL) but still about 11 times higher than median abundance on May 26 (2,044 cells/mL). Cyanobacterial abundances also varied substantially (the range was from 1,420 to 53,900 cells $/ \mathrm{mL}$ ) throughout Zone C. As observed on July 21, there were no clear patterns in phytoplankton or cyanobacterial abundances throughout Zone C (fig. 13). Cyanobacterial abundances on September 15 did not exceed KDHE guidance values.
On September 15, the algal community north of the causeway $(n=2)$ was dominated by diatoms (about 70 and 86 percent of total phytoplankton abundance). The algal community throughout the rest of Zone $\mathrm{C}$ was dominated by cyanobacteria (79 to 97 percent of total phytoplankton abundance). The cyanobacterial community was more diverse on September 15 than on May 26, and the dominant genera varied by location. Microcystis dominated (greater than 50 percent of total cyanobacterial abundance) the cyanobacterial community at 50 percent of sample locations, Aphanizomenon dominated at 20 percent of locations, Dolichospermum (formerly Anabaena) and Planktolyngbya each dominated at 10 percent of locations, and Aphanizomenon and Dolichospermum (formerly Anabaena) codominated at 10 percent of locations.

On September 15, chlorophyll concentrations in Zone C ranged from 15.8 to $57.8 \mu \mathrm{g} / \mathrm{L}$. The median chlorophyll concentration on September $15(29.0 \mu \mathrm{g} / \mathrm{L})$ was similar to the median concentration observed on May $26(26.7 \mu \mathrm{g} / \mathrm{L})$. There were no clear spatial patterns in algal biomass (as indicated by chlorophyll concentrations) on September 15, though biomass still tended to be higher in the northern part of the zone and lower in the transitional area between Zones C and B, as observed on May 26 and July 21 (figs. 7, 10, and 13).

Discrete microcystin concentrations in Zone $\mathrm{C}$ ranged from $<0.1$ to $6.50 \mu \mathrm{g} / \mathrm{L}$ (the median was $1.50 \mu \mathrm{g} / \mathrm{L}$ ) on September 15. Discrete microcystin concentration exceeded the KDHE guidance value for watch status $(4 \mu \mathrm{g} / \mathrm{L})$ in one sample collected on September 15. Microcystin was not detected north of the causeway on September 15 but was detected throughout the rest of Zone C. Discrete microcystin concentrations were less variable throughout the lower parts of Zone C on May 26 than observed on July 21 and September 15 (figs. 7, 10, and 13). With the exception of one sample, concentrations varied by less than a factor of two.

\section{Spatial Survey Results}

Regression-estimated chlorophyll concentrations were used to describe the distribution of algal biomass at 0.5 - and 1.5-m depths in Zone C of Milford Lake on September 15, 2016. Regression-estimated chlorophyll concentrations at a $0.5-\mathrm{m}$ depth during the first spatial survey ranged from 8.26 to $98.9 \mu \mathrm{g} / \mathrm{L}(n=294)$ and varied by a factor of about 12 throughout Zone $\mathrm{C}$. The maximum regression-estimated chlorophyll concentrations at a $0.5-\mathrm{m}$ depth during the second spatial survey were lower than the first spatial survey, ranging from 11.4 to $70.8 \mu \mathrm{g} / \mathrm{L}(n=310)$, and varied by a factor of about 6 . Overall, median regression-estimated chlorophyll concentrations were similar between spatial surveys (24.0 and $22.5 \mu \mathrm{g} / \mathrm{L}$ during the first and second surveys, respectively) (table 6; fig. 14). Median regression-estimated chlorophyll concentrations at a $0.5-\mathrm{m}$ depth on September 15 were lower than observed on July 21 but still about two to three times higher than observed on May 26 (tables 4, 5, and 6). 


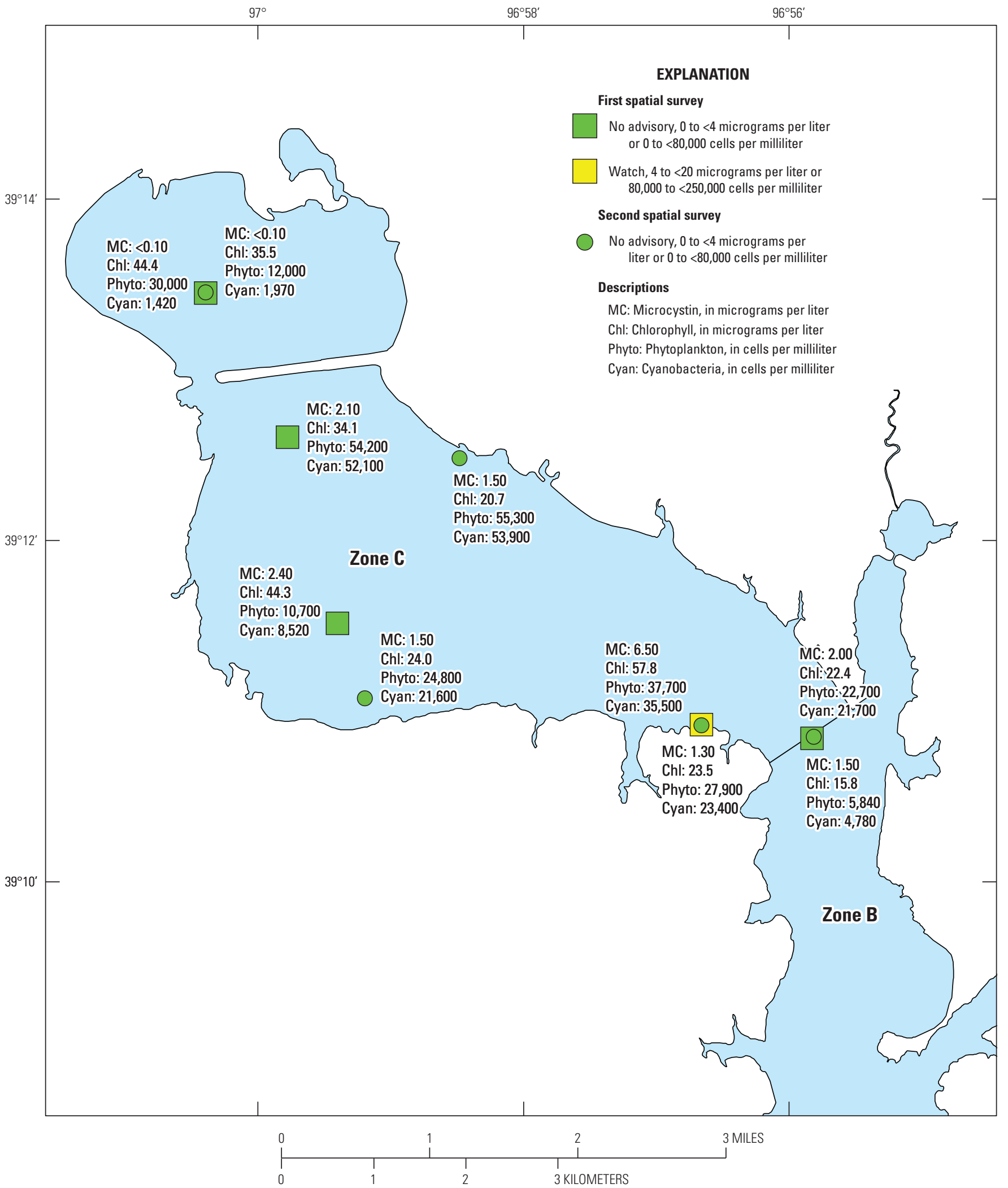

Figure 13. Discrete phytoplankton and cyanobacterial abundances and chlorophyll and microcystin concentrations in Zone $\mathrm{C}$ of Milford Lake on September 15, 2016. 
Table 6. Summary statistics for regression-estimated chlorophyll and microcystin concentrations in Zone C of Milford Lake on September 15, 2016.

[ $n$, number of regression-estimated values; \pm , plus or minus; PI, 95-percent prediction interval (Neter and others, 1996); <, less than]

\begin{tabular}{|c|c|c|c|c|c|c|c|c|}
\hline \multirow{2}{*}{$\begin{array}{l}\text { Spatial } \\
\text { survey }\end{array}$} & \multirow{2}{*}{$n$} & \multicolumn{3}{|c|}{ Top monitor (0.5-meter depth) } & \multirow{2}{*}{$n$} & \multicolumn{3}{|c|}{ Bottom monitor (1.5-meters depth) } \\
\hline & & Minimum \pm PI & Maximum $\pm \mathbf{P I}$ & Median \pm PI & & Minimum \pm PI & Maximum \pm PI & Median \pm PI \\
\hline \multicolumn{9}{|c|}{ Chlorophyll, in micrograms per liter } \\
\hline 2 & 310 & $11.4( \pm 46)$ & $70.8( \pm 46)$ & $22.5( \pm 46)$ & 310 & $17.2( \pm 46)$ & $71.1( \pm 46)$ & $27.1( \pm 46)$ \\
\hline \multicolumn{9}{|c|}{ Total microcystin, in micrograms per liter } \\
\hline 2 & 310 & $<0.07( \pm 19)$ & $13.1( \pm 19)$ & $<0.07( \pm 19)$ & 310 & $<0.01( \pm 19)$ & $13.1( \pm 19)$ & $0.93( \pm 19)$ \\
\hline
\end{tabular}

Regression-estimated chlorophyll concentrations at a 1.5-m depth during the first spatial survey ranged from 12.6 to $89.0 \mu \mathrm{g} / \mathrm{L}(n=294)$ and varied by a factor of about 7 throughout Zone $\mathrm{C}$. The maximum regression-estimated chlorophyll concentrations at a $1.5-\mathrm{m}$ depth during the second spatial survey were lower than the first survey, ranging from 17.2 to $71.1 \mu \mathrm{g} / \mathrm{L}(n=310)$, and varied by a factor of about 4. Overall, median regression-estimated chlorophyll concentrations were similar between spatial surveys (27.4 and $27.1 \mu \mathrm{g} / \mathrm{L}$ during the first and second surveys, respectively) (table 6; fig. 15).

Regression-estimated microcystin concentrations were used to describe the distribution of algal toxins at 0.5- and 1.5-m depths in Zone C of Milford Lake on September 15, 2016. Regression-estimated microcystin concentrations at a $0.5-\mathrm{m}$ depth in Zone $\mathrm{C}$ during the first spatial survey ranged from $<0.07$ to $20.9 \mu \mathrm{g} / \mathrm{L}$, with a median regressionestimated concentration of $<0.07 \mu \mathrm{g} / \mathrm{L}(n=296)$. Regressionestimated microcystin concentrations at a $0.5-\mathrm{m}$ depth in Zone $\mathrm{C}$ during the second spatial survey ranged from $<0.07$ to $13.1 \mu \mathrm{g} / \mathrm{L}$, with a median regression-estimated concentration of $<0.07 \mu \mathrm{g} / \mathrm{L}(n=310)$ (table 6; fig. 16). Median regressionestimated microcystin concentrations at a $0.5-\mathrm{m}$ depth on September 15 were the same as observed on May 26 $(<0.07 \mu \mathrm{g} / \mathrm{L})$. Median regression-estimated microcystin concentrations at a $0.5-\mathrm{m}$ depth on September 15 were below the detection threshold $(<0.07 \mu \mathrm{g} / \mathrm{L})$, whereas median concentrations observed on July 21 were $16.8 \mu \mathrm{g} / \mathrm{L}$ for the first spatial survey and $12.3 \mu \mathrm{g} / \mathrm{L}$ for the second spatial survey (tables 4, 5, and 6).

Regression-estimated microcystin concentrations at a 1.5-m depth in Zone $\mathrm{C}$ for the first spatial survey ranged from $<0.07$ to $18.1 \mu \mathrm{g} / \mathrm{L}$, with a median regression-estimated concentration of $1.02 \mu \mathrm{g} / \mathrm{L}(n=294)$. Regression-estimated microcystin concentrations at a 1.5-m depth in Zone $\mathrm{C}$ for the second spatial survey ranged from $<0.07$ to $13.1 \mu \mathrm{g} / \mathrm{L}$, with a median regression-estimated concentration of $0.93 \mu \mathrm{g} / \mathrm{L}$ $(n=310)$ (table 6; fig. 17).

Most regression-estimated microcystin concentrations on September 15 did not exceed KDHE guidance values.
During the first spatial survey, 79 percent of regressionestimated microcystin concentrations at a $0.5-\mathrm{m}$ depth and 84 percent at a $1.5-\mathrm{m}$ depth were lower than the guidance value for watch status $(4 \mu \mathrm{g} / \mathrm{L})$. About 21 and 16 percent of regression-estimated concentrations at 0.5 - and $1.5-\mathrm{m}$ depths, respectively, were above guidance values for watch status. Less than 1 percent of estimated concentrations at a 0.5-m depth exceeded the guidance value for warning status $(20 \mu \mathrm{g} / \mathrm{L})$. A total of 22 percent of estimated concentrations at a 1.5-m depth exceeded the guidance value for watch status ( $4 \mu \mathrm{g} / \mathrm{L})$ but concentrations did not exceed the warning status $(20 \mu \mathrm{g} / \mathrm{L})$. During the second spatial survey, 76 percent of regression-estimated microcystin concentrations at a $0.5-\mathrm{m}$ depth and 80 percent at a $1.5-\mathrm{m}$ depth were lower than the guidance value for watch status. About 24 and 20 percent of regression-estimated concentrations at 0.5 - and $1.5-\mathrm{m}$ depths, respectively, were above the guidance value for watch status. The guidance value for warning status was not exceeded during the second spatial survey.

Regression-estimated chlorophyll and microcystin concentrations generally reflect the patterns observed in discrete data; however, the spatial data illustrate patterns in the distribution that could not be discerned based on discrete data alone. Patterns observed between the two spatial surveys indicate northward movement of the cyanobacterial bloom consistent with the wind shift noted from the previous day. On September 14, winds were generally from the north to northwest, shifting direction to the south by September 15 (parts $C$ and $D$ on figures 14-17). Northward progression of regression-estimated chlorophyll and microcystin between the two spatial surveys, at 0.5 - and $1.5-\mathrm{m}$ depths, is displayed in parts $A$ and $B$ in figures 14 through 17. These data, along with the camera data and spatial and wind data from May and July indicated that wind can be a major driver of the spatial and temporal variability of cyanobacterial blooms in Milford Lake and likely plays a role in the extent and duration of near-shore accumulations. Surface accumulation of blooms may develop and dissipate within a matter of hours as wind and weather conditions change, resulting in extreme spatial and temporal variability (Graham and others, 2016). 


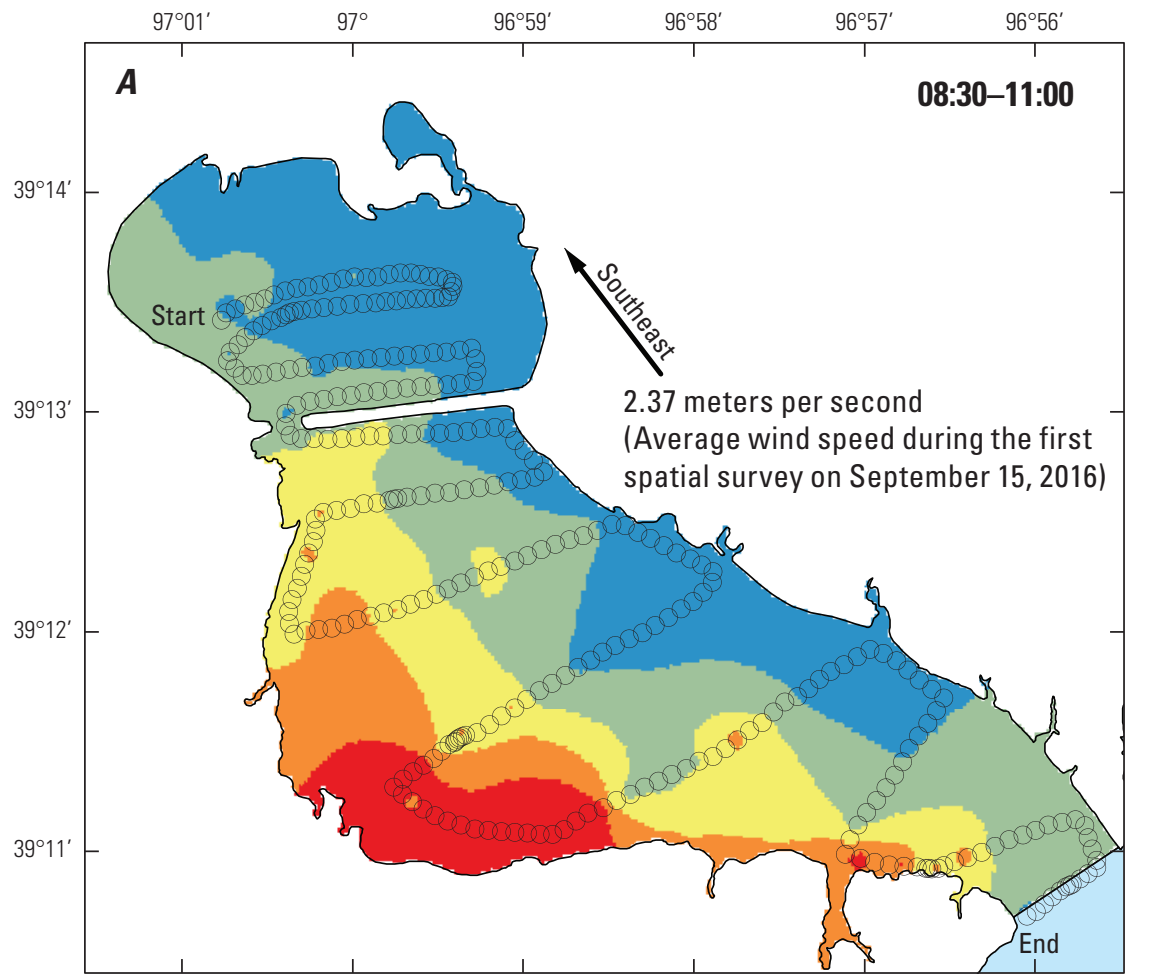

EXPLANATION

Regression-estimated chlorophyll, in micrograms per liter

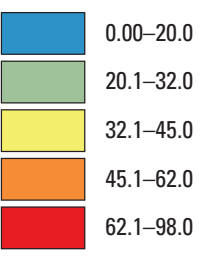

Boat path

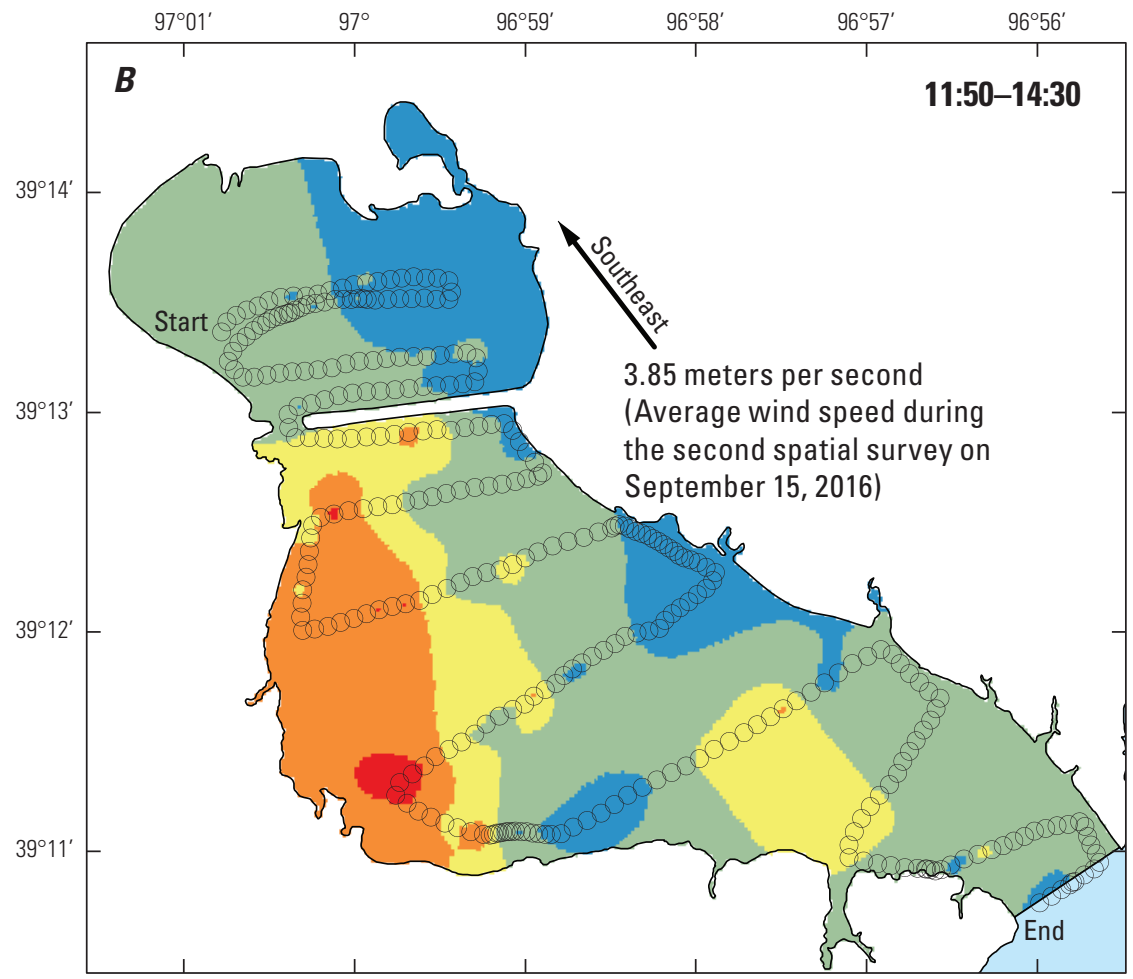

3 MILES
C. Day before survey

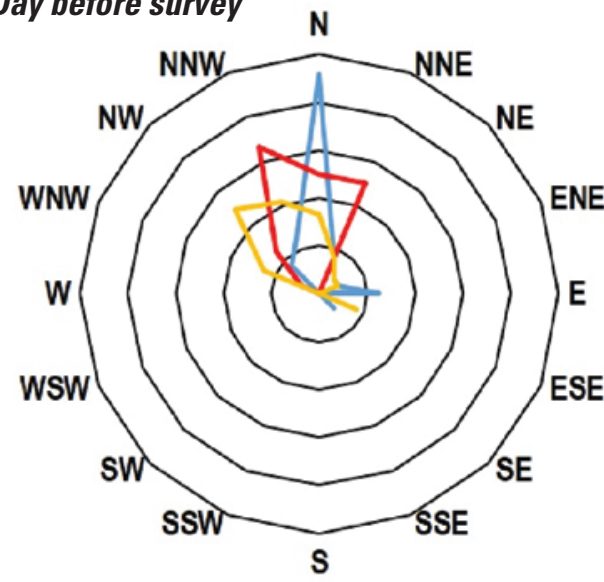

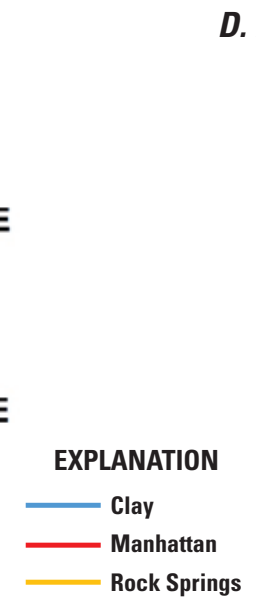

D. Day of survey

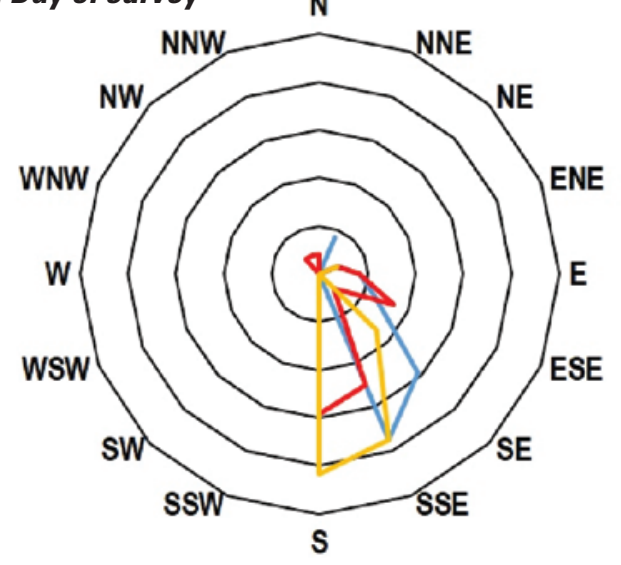

Wind rose diagrams represent the relative frequency the wind was coming from a certain direction.

Figure 14. Regression-estimated chlorophyll concentrations at a 0.5-meter depth in Zone $C$ of Milford Lake on September 15, 2016. $A$, first spatial survey; $B$, second spatial survey; $C$, wind rose diagram displaying relative frequency for hourly wind direction on September 14, 2016; and $D$, wind rose diagram displaying relative frequency for hourly wind direction on the day of the spatial survey, September 15, 2016. 

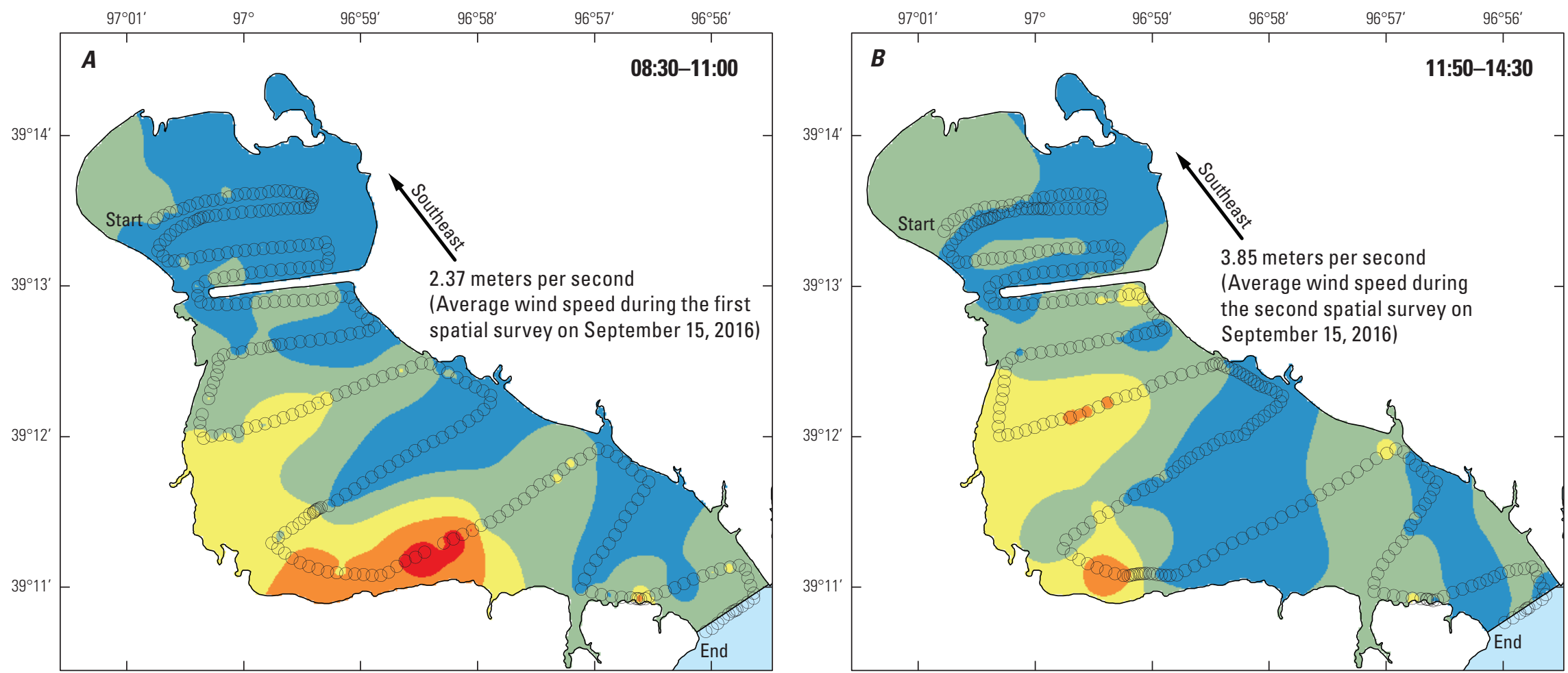

\section{EXPLANATION}

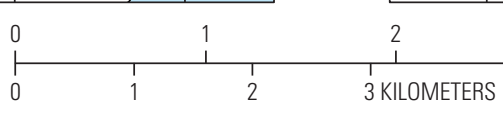

3 MILES

Regression-estimated chlorophyll, in micrograms per liter

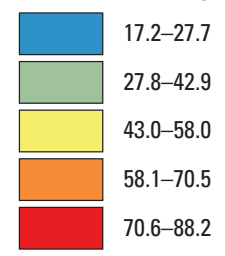

Boat path

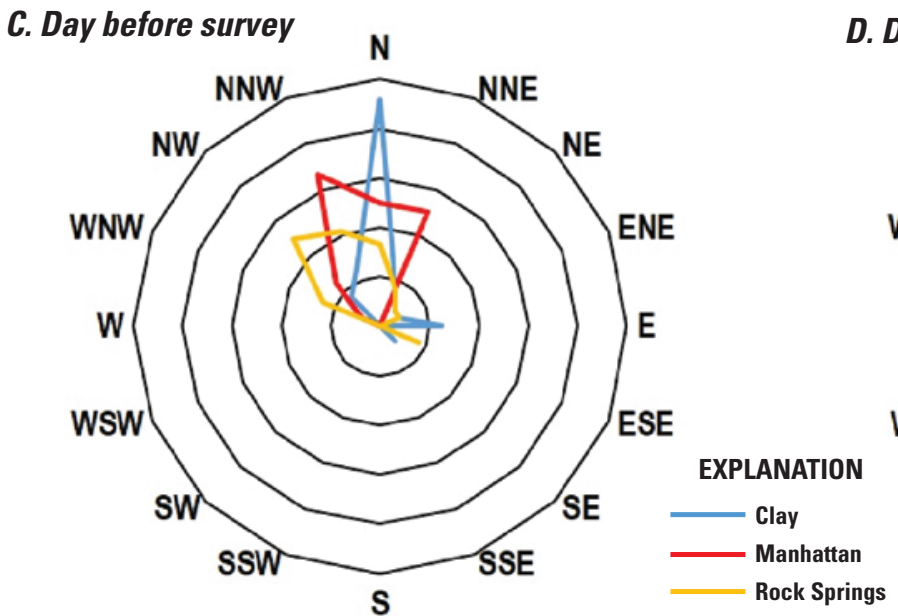

Figure 15. Regression-estimated chlorophyll concentrations at a 1.5-meter depth in Zone C of Milford Lake on September 15, 2016. $A$, first spatial survey; $B$, second spatial survey; $C$, wind rose diagram displaying relative frequency for hourly wind direction on September 14, 2016; and $D$, wind rose diagram displaying relative frequency for hourly wind direction on the day of the spatial survey, September 15, 2016.

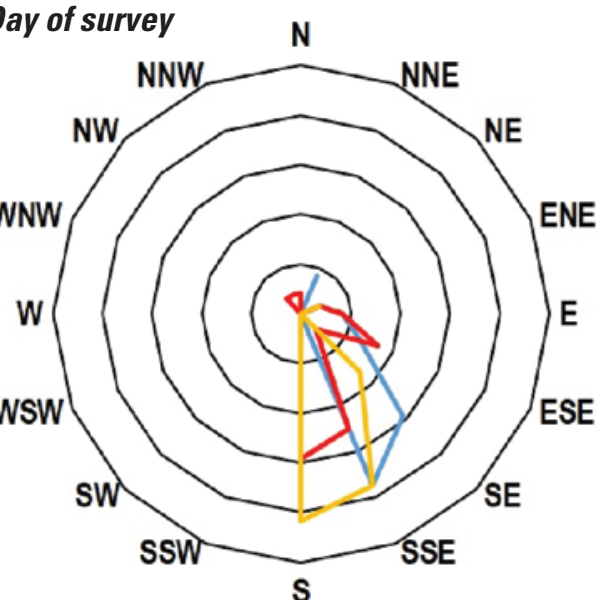



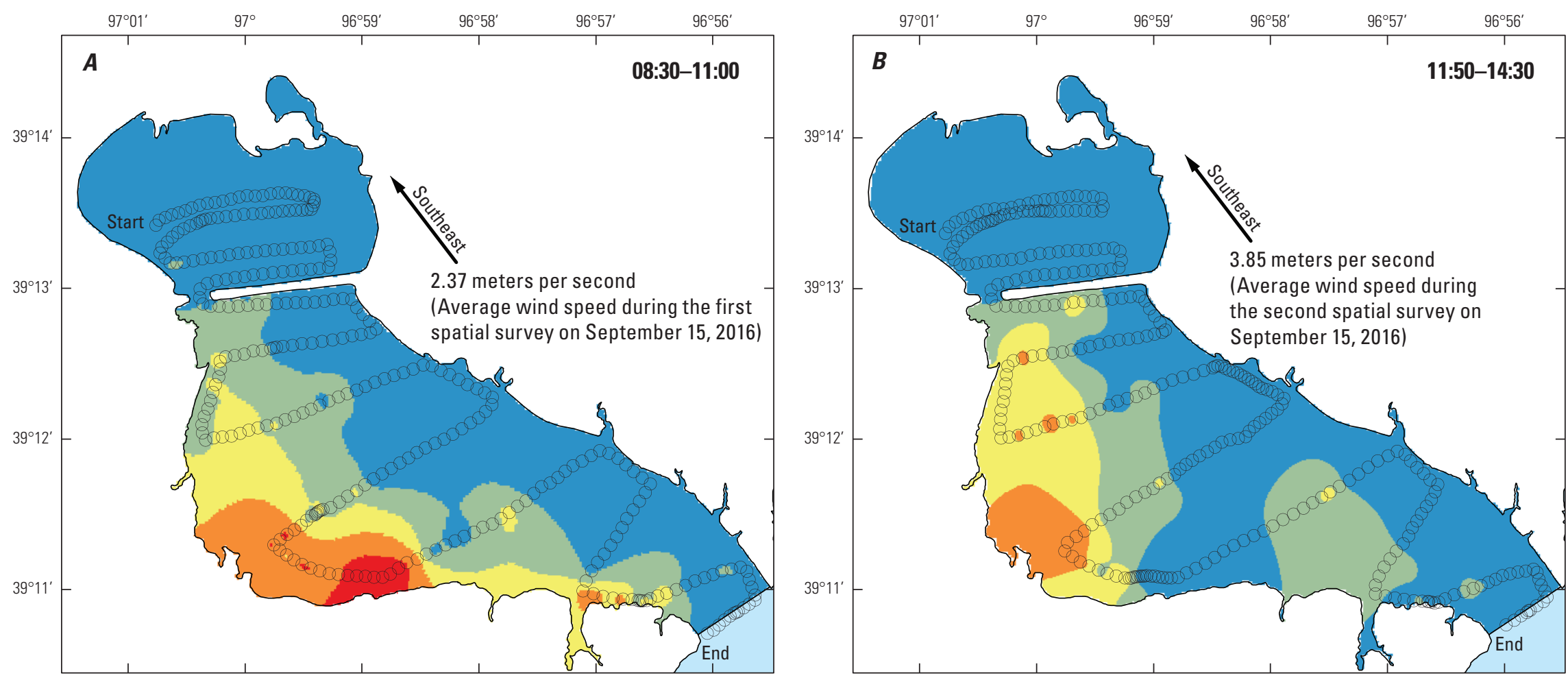

EXPLANATION

1

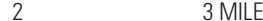

Regression-estimated microcystin

in micrograms per liter

C. Day before survey

3 KILOMETERS
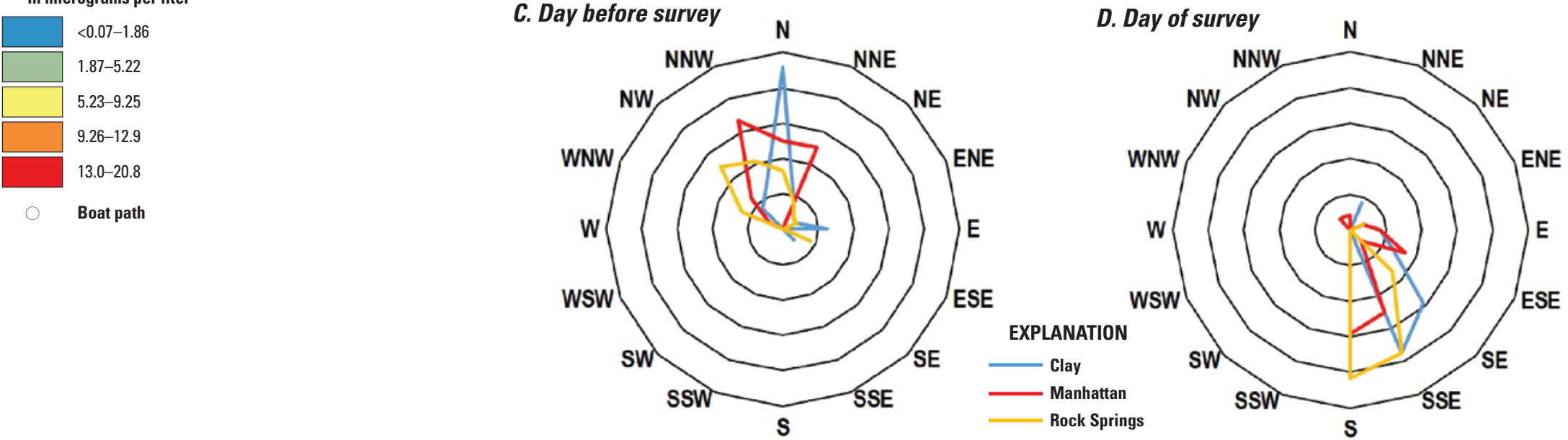

Wind rose diagrams represent the relative frequency the wind was coming from a certain direction.

Figure 16. Regression-estimated microcystin concentrations at a 0.5-meter depth in Zone $C$ of Milford Lake on September 15, 2016. $A$, first spatial survey; $B$, second spatial survey; $C$, wind rose diagram displaying relative frequency for hourly wind direction on September 14, 2016; and $D$, wind rose diagram displaying relative frequency for hourly wind direction on the day of the spatial survey, September 15, 2016. Model censored data at 0.07 micrograms per liter. 

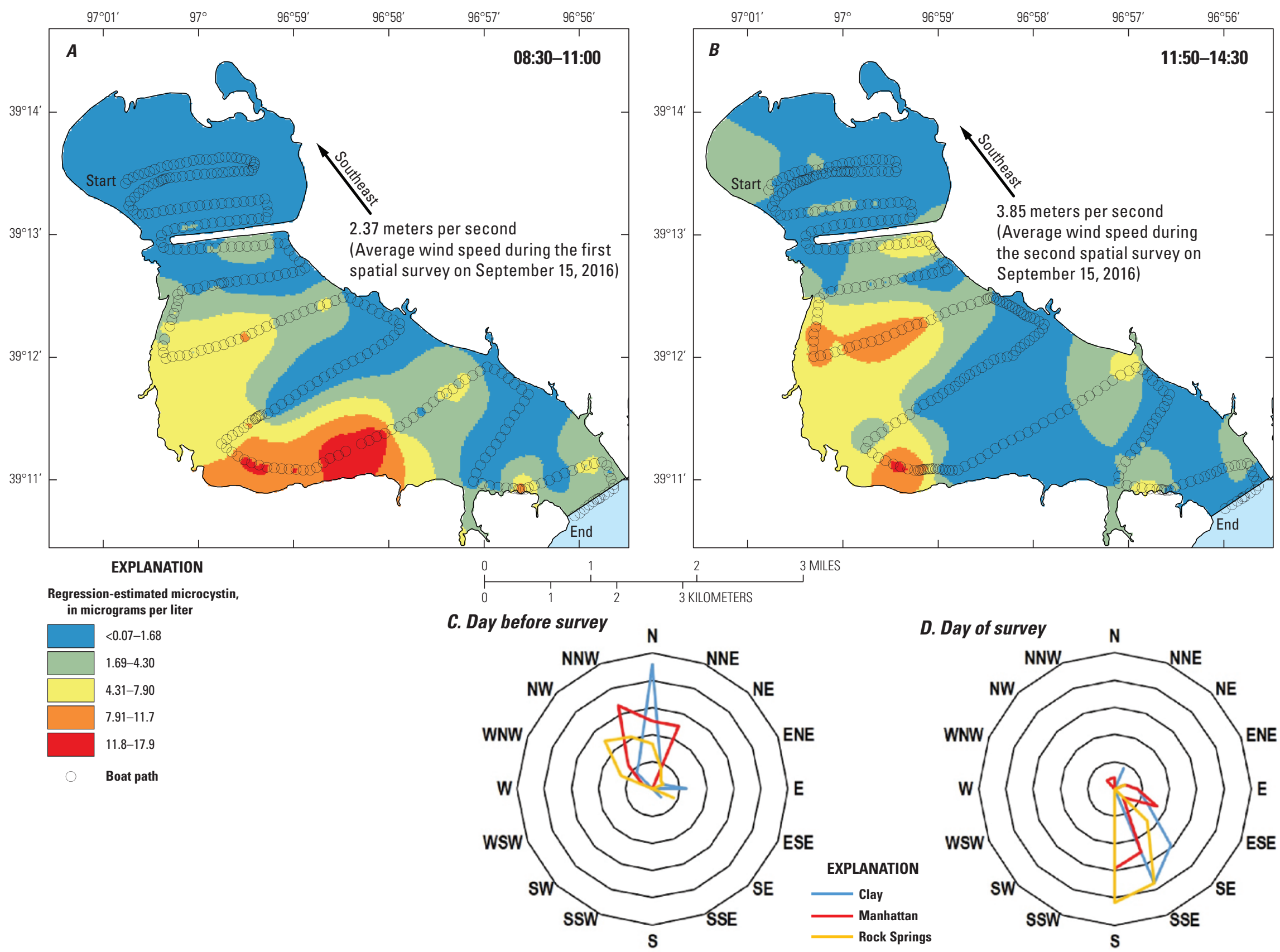

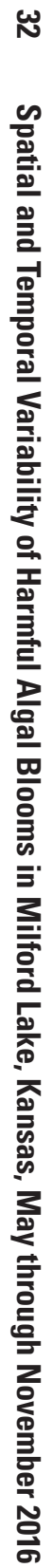

Wind rose diagrams represent the relative frequency the wind was coming from a certain direction.

Figure 17. Regression-estimated microcystin concentration at a 1.5-meter depth in Zone $C$ of Milford Lake on September 15, 2016. $A$, first spatial survey; $B$, second spatial survey; $C$, wind rose diagram displaying relative frequency for hourly wind direction on September 14, 2016; and $D$, wind rose diagram displaying relative frequency for hourly wind direction on the day of the spatial survey, September 15, 2016. Model censored data at 0.07 micrograms per liter. 


\section{Summary}

Problems associated with cyanobacterial harmful algal blooms (CyanoHABs) include reductions in water quality, malodorous accumulations along shorelines, production of taste-and-odor compounds that cause unpalatable drinking water and fish flesh, and production of toxins potent enough to poison aquatic and terrestrial organisms. Many States, including Kansas, have established monitoring programs for recreational water bodies to protect public health. Milford Lake has been under Kansas Department of Health and Environment (KDHE) CyanoHAB advisories every summer since 2011. The only zone of Milford Lake that has experienced blooms severe enough to warrant closure is "Zone C" (the upstream one-third of the reservoir). Extreme spatial and temporal variability is characteristic of CyanoHABs. Because of inlake and weather-driven processes, CyanoHABs can vary by orders of magnitude in concentration across short distances (meters or less). In 2016, the U.S. Geological Survey, in cooperation with KDHE, completed a study to quantify the spatial variability of cyanobacterial blooms in Zone $\mathrm{C}$ over a range of environmental conditions and quantify the temporal variability of blooms in Zone $\mathrm{C}$ at various time scales (hours to months). A better understanding of the spatial and temporal variability of cyanobacteria and microcystin will inform sampling and management strategies for Milford Lake and for other lakes with CyanoHAB issues throughout the Nation. Spatial and temporal variability were assessed during May through November 2016 using a combination of time-lapse photography; continuous water-quality monitors; discrete phytoplankton, chlorophyll, and microcystin samples; and spatially dense near-surface data. Combined, these data were used to characterize variability of cyanobacterial abundance, algal biomass, and microcystin concentrations in Zone $\mathrm{C}$ of Milford Lake before, during, and after cyanobacterial blooms in 2016.

Time-lapse cameras were installed at six locations around Zone $\mathrm{C}$ of Milford Lake to visually capture the variability of cyanobacterial blooms. Cyanobacteria were in 48 percent of usable images across all sites, possibly in 14 percent of images, and absent from 38 percent of images. All sites had visual evidence of cyanobacterial blooms from early July until cameras were removed in late November. Bloom accumulation at each site was dependent on wind direction. After a change in wind direction, it would take about 1 day for accumulations to become visible at different locations. During periods with low wind, accumulations were widespread and visible at all sites.

Discrete water-quality samples for the analysis of phytoplankton community composition and chlorophyll and microcystin concentrations were collected at the Wakefield site to broadly characterize seasonal patterns during May through November 2016. A continuous water-quality monitor also was operated at the Wakefield site. Continuously measured phycocyanin relative fluorescence units were used to estimate chlorophyll and microcystin concentrations at the Wakefield site using the regression models developed with spatial data.
Although the models were not developed specifically for the Wakefield site, regression-estimated concentrations likely are more indicative of seasonal patterns in algal biomass (indicated by chlorophyll) and microcystin than discretely collected samples.

Cyanobacteria were absent from the algal community at the Wakefield site in late May and were a minor component of the community in June; however, by mid-July, the cyanobacteria were dominant and remained dominant until early November. Cyanobacterial abundance at the Wakefield site increased from May through November, with an observed maximum in early November. Overall, cyanobacterial abundances in discrete samples were low and did not exceed KDHE guidance values for public-health protection.

Regression-estimated chlorophyll concentrations likely are more indicative of seasonal patterns in algal biomass than the five discretely collected chlorophyll samples at the Wakefield site because these data have a much higher temporal resolution. Based on regression-estimated chlorophyll concentrations, algal biomass at the Wakefield site steadily increased from May through August. Monthly median chlorophyll concentrations increased most rapidly between May and July. After August, algal biomass decreased but remained relatively high compared to May and June. Although broad seasonal patterns were discernible, there was a substantial amount of variability. Daily chlorophyll maxima were as much as 400 times higher than daily minima. Variability was highest during July and August when algal biomass also was high. The extreme variability in algal biomass at the Wakefield site reflects the development and dissipation of blooms, as indicated by the time-lapse cameras.

Regression-estimated microcystin concentrations likely are more indicative of seasonal patterns in algal biomass than the five discretely collected samples at the Wakefield site because these data have a much higher temporal resolution. Like algal biomass, regression-estimated microcystin concentrations steadily increased from May through August. Monthly median regression-estimated microcystin concentrations increased most rapidly between May and July. After August, regression-estimated microcystin concentrations decreased but remained higher than observed in May and June. As observed for algal biomass, there was a substantial amount of variability in regression-estimated microcystin concentrations at the Wakefield site. Daily regressionestimated microcystin maxima were as many as several orders of magnitude higher than daily minima. Variability in regression-estimated microcystin concentration also was highest during July and August. KDHE watch and warning thresholds for microcystin were exceeded during mid-June through late November. Based on regression-estimated microcystin concentrations, exceedance of KDHE advisory thresholds often changed from no advisory to watch and (or) warning over the course of the day because of the variability in algal biomass and microcystin concentrations caused by bloom development and dissipation. However, during 2 weeks in August and 3 weeks in September, regression-estimated microcystin concentrations always exceeded watch and warning thresholds. 
Weekly mean regression-estimated microcystin concentrations were calculated for the Wakefield site and used to determine advisory status based on KDHE thresholds. Regression-estimated advisory status at the Wakefield site matched KDHE advisory status 47 percent of the time. If weekly maxima in regression-estimated microcystin concentrations are used for comparison instead of weekly means, regression-estimated advisory status matched KDHE advisory status 89 percent of the time. Results from this study indicate that continuous water-quality monitors may be useful in informing public-health decisions in lakes with variable CyanoHAB conditions; however, site-specific models need to be developed, and best practices for using continuous waterquality monitors to inform CyanoHAB management strategies need to be established.

Spatial data were collected on May 26, July 21, and September 15, 2016, using a combination of a boatmounted sensor array and discrete water-quality samples analyzed for phytoplankton community composition and chlorophyll and microcystin concentrations. Following the same route throughout Zone $\mathrm{C}$, two consecutive spatial surveys were completed to characterize changing conditions throughout the course of the day. Spatial patterns were described using regression-estimated chlorophyll and microcystin concentrations.

During May 26, 2016, cyanobacterial abundances were low throughout Zone $\mathrm{C}$ and did not exceed KDHE guidance values. The algal community in Zone $\mathrm{C}$ was dominated by diatoms at most locations. Cyanobacteria dominated or codominated the algal community with diatoms at the three locations in the transitional area between Zones C and B (Zone B is the middle zone of Milford Lake). Microcystis (a known microcystin producer and the dominant bloom-causing genera in Milford Lake) was only in 25 percent of sample locations and only in the transitional area between Zones $\mathrm{C}$ and B. Based on discrete samples, algal biomass was about five to eight times higher north of the causeway than in the transitional area between Zones C and B. Discrete microcystin concentrations in Zone $\mathrm{C}$ did not exceed KDHE guidance values. Spatial patterns in discrete microcystin did not match patterns in phytoplankton abundance or algal biomass. Microcystin was not detected north of the causeway, where algal biomass was highest, but was consistently detected from the middle of Zone $\mathrm{C}$ into the transitional area between Zones $\mathrm{C}$ and $\mathrm{B}$. In the transitional area between Zones $\mathrm{C}$ and $\mathrm{B}$, overall phytoplankton and cyanobacterial abundances were low, but cyanobacteria dominated the algal community at these locations and Microcystis was present.

On May 26, 2016, the median regression-estimated chlorophyll concentration during the first spatial survey was about 1.6 times higher than in the second spatial survey, indicating that algal distribution in the water column may have changed between the two runs. Regression-estimated chlorophyll concentrations were indicative of higher algal biomass uplake in Zone $\mathrm{C}$, with decreases in the downlake direction towards Zone B. Regression-estimated chlorophyll concentrations also were more variable uplake than downlake. Spatial maps indicated changes in algal distribution at a 0.5 -meter $(\mathrm{m})$ depth between the two paired runs. Changes in distribution between the two spatial surveys may have been caused by algal movement horizontally or vertically in the water column. Based on regression estimates, microcystin concentrations did not exceed KDHE guidance values anywhere in Zone C. Variability in regression-estimated microcystin concentrations was small throughout Zone $\mathrm{C}$ on May 26, reflecting conditions before the cyanobacterial bloom in the lake. Spatial patterns in regression-estimated microcystin throughout Zone $\mathrm{C}$ did not match patterns in regression-estimated chlorophyll concentrations, likely because the algal community was not dominated by cyanobacteria at most locations on May 26. In contrast to discrete samples, the highest regression-estimated microcystin concentrations were observed north of the causeway during the second survey. Differences between discrete and estimated microcystin distributions may have been caused by discrete sample location, changes in algal distribution, or error associated with regression estimation.

During July 21, 2016, cyanobacterial abundances in Zone $\mathrm{C}$ exceeded KDHE guidance values in 50 percent of samples. The algal community in Zone $\mathrm{C}$ was dominated by cyanobacteria at all locations except two, where cyanobacteria codominated with diatoms. Both locations where cyanobacteria and diatoms codominated were north of the causeway. The cyanobacterial community was dominated by Microcystis throughout Zone C on July 21 . The only exception was observed at the transition between Zones $\mathrm{C}$ and B, where Microcystis and Dolichospermum (formerly Anabaena) codominated the cyanobacterial community. Based on discrete samples, algal biomass was higher in the northern part of the zone and lower in the transitional area between Zones $\mathrm{C}$ and $\mathrm{B}$. Microcystin concentrations exceeded KDHE guidance values in all discrete samples collected on July 21. Though microcystin concentrations were variable throughout Zone $\mathrm{C}$, concentrations were lowest in the transitional area between Zones $\mathrm{C}$ and $\mathrm{B}$, similar to the pattern observed in algal biomass.

On July 21, 2016, the median regression-estimated chlorophyll concentration during the first spatial survey was about 1.2 times higher than the second spatial survey. Spatial patterns in regression-estimated chlorophyll concentrations were similar to those observed in discrete samples, with a higher level of resolution. Regression-estimated chlorophyll concentrations were indicative of higher algal biomass north of the causeway and on the eastern shore of Zone C. On July 21, algal biomass did not necessarily decrease in the downlake direction. There was a decrease just south of the causeway but an increase shortly after with higher concentrations into Zone B. Spatial maps indicated changes in algal distribution at a $0.5-\mathrm{m}$ depth between the two paired runs, with algae moving to the central part of the lake north of the causeway and along the eastern shore south of the causeway. Most 
regression-estimated microcystin concentrations on July 21 exceeded KDHE guidance values, reflecting the pervasive bloom conditions in Zone $\mathrm{C}$ during this period. During the first spatial survey, 41 percent of regression-estimated microcystin concentrations exceeded the guidance value for watch status and 43 percent exceeded the guidance value for warning status. By comparison, during the second spatial survey, 49 percent of regression-estimated microcystin concentrations exceeded the guidance value for watch status and 33 percent exceeded the guidance value for warning status, reflecting the changing conditions in Zone $\mathrm{C}$ throughout the day. Spatial patterns in regression-estimated microcystin concentrations throughout Zone $\mathrm{C}$ were similar to patterns seen in discrete samples and regression-estimated chlorophyll concentrations, with higher concentrations north of the causeway and on the east shore of Zone C. High regression-estimated microcystin concentrations were localized to a few areas upstream from the causeway and one area on the east shore of Zone $\mathrm{C}$ close to the boundary with Zone B. Spatial maps indicate changes in regression-estimated microcystin distribution similar to those observed for algal biomass at a $0.5-\mathrm{m}$ depth between the two paired runs.

During September 15, 2016, cyanobacterial abundances did not exceed KDHE guidance values. On September 15, the algal community north of the causeway was dominated by diatoms. The algal community throughout the rest of Zone $\mathrm{C}$ was dominated by cyanobacteria. The cyanobacterial community was more diverse on September 15 than on May 26, and the dominant genera varied by location. Microcystis dominated the cyanobacterial community at 50 percent of sample locations. Based on discrete samples, there were no clear spatial patterns in algal biomass on September 15, though biomass still tended to be higher in the northern part of the zone and lower in the transitional area between Zones C and B, as observed on May 26 and July 21. Discrete microcystin concentrations exceeded the KDHE guidance value for watch status in one sample collected on September 15. Discrete microcystin was not detected north of the causeway on September 15 but was detected throughout the rest of Zone C. Discrete microcystin concentrations were less variable throughout the lower parts of Zone $\mathrm{C}$ on September 15 than observed on May 26 and July 21.

On September 15, 2016, median regression-estimated chlorophyll concentrations at $0.5-\mathrm{m}$ and $1.5-\mathrm{m}$ depths were similar between spatial surveys. Most regression-estimated microcystin concentrations on September 15 did not exceed KDHE guidance values. During the first spatial survey, 79 percent of regression-estimated microcystin concentrations at a $0.5-\mathrm{m}$ depth and 84 percent at a $1.5-\mathrm{m}$ depth were lower than the guidance value for watch status. About 21 and 16 percent of regression-estimated concentrations at 0.5 - and 1.5-m depths, respectively, were above guidance values for watch status. Less than 1 percent of estimated concentrations at a $0.5-\mathrm{m}$ depth exceeded the guidance value for warning status (20 micrograms per liter $[\mu \mathrm{g} / \mathrm{L}])$. A total of 22 percent of estimated concentrations at a $1.5-\mathrm{m}$ depth exceeded the guidance value for watch status $(4 \mu \mathrm{g} / \mathrm{L})$, but concentrations did not exceed the warning status $(20 \mu \mathrm{g} / \mathrm{L})$. During the second spatial survey, 76 percent of regression-estimated microcystin concentrations at a $0.5-\mathrm{m}$ depth and 80 percent at a $1.5-\mathrm{m}$ depth were lower than the guidance value for watch status. About 24 and 20 percent of regression-estimated concentrations at 0.5 - and 1.5-m depths, respectively, were above the guidance value for watch status. The guidance value for warning status was not exceeded during the second spatial survey. Regression-estimated chlorophyll and microcystin concentrations generally reflect the patterns observed in discrete data; however, the spatial data illustrate patterns in the distribution that could not be discerned based on discrete data alone. Patterns observed between the two spatial runs indicate northward movement of the cyanobacterial bloom consistent with the wind shift noted from the previous day. On September 14, winds were generally from the north to northwest, shifting direction to the south by September 15 . There was a northward progression of chlorophyll and microcystin between the two spatial runs, at 0.5 - and $1.5-\mathrm{m}$ depths. These data, along with the camera data and spatial and wind data from May and July, indicated that wind can be a major driver of the spatial and temporal variability of cyanobacterial blooms in Milford Lake and likely plays a role in the extent and duration of near-shore accumulations.

\section{References Cited}

Bennett, T.J., Graham, J.L., Foster, G.M., Stone, M.L., Juracek, K.E., Rasmussen, T.J., and Putnam, J.E., 2014, U.S. Geological Survey quality-assurance plan for continuous water-quality monitoring in Kansas, 2014: U.S. Geological Survey Open-File Report 2014-1151, 34 p. plus appendixes, accessed December 2017 at https://doi.org/10.3133/ofr20141151.

Foster, G.M., Graham, J.L., Stiles, T.C., Boyer, M.G., King, L.R., and Loftin, K.A., 2017, Spatial variability of harmful algal blooms in Milford Lake, Kansas, July and August 2015: U.S. Geological Survey Scientific Investigations Report 2016-5168, 45 p., accessed December 2017 at https://doi.org/10.3133/sir20165168.

Graham, J.L., Loftin, K.A., Ziegler, A.C., and Meyer, M.T., 2008, Cyanobacteria in lakes and reservoirs-Toxin and taste-and-odor sampling guidelines (ver. 1.0): U.S. Geological Survey Techniques of Water-Resources Investigations, book 9, chap. A7, section 7.5, accessed December 2017 at https://pubs.water.usgs.gov/twri9A/.

Graham, J.L., Loftin, K.A., and Kamman, N., 2009, Monitoring recreational freshwaters: LakeLine, v. 29, p. 16-22. 
Graham, J.L., Dubrovsky, N.M., and Eberts, S.M., 2016, Cyanobacterial harmful algal blooms and U.S. Geological Survey science capabilities (ver. 1.1, December 2017): U.S. Geological Survey Open-File Report 2016-1174, 12 p. [Also available at https://doi.org/10.3133/ofr20161174.]

Hambrook Berkman, J.A., and Canova, M.G., 2007, Algal biomass indicators (ver. 1.0): U.S. Geological Survey Techniques of Water-Resources Investigations, book 9 , chap. A7, section 7.4, accessed October 21, 2016, at https://pubs.water.usgs.gov/twri9A/.

Helsel, D.R., and Hirsch, R.M., 2002, Statistical methods in water resources-Hydrologic analysis and interpretation: U.S. Geological Survey Techniques of Water-Resources Investigations, book 4, chap. A3, 522 p., accessed December 2017 at https://pubs.usgs.gov/twri/twri4a3/html/toc.html.

Kansas Department of Health and Environment, 2015, Policy - Guidelines for addressing harmful algal blooms in Kansas recreational waters: KDHE Internal Directive 1101.1, accessed October 20, 2016, at http://www.kdheks.gov/algae-illness/download/HAB policy.pdf.

Kansas Department of Health and Environment, 2016, Historical HABs: Kansas Department of Health and Environment web page, accessed December 4, 2017, at http://www.kdheks.gov/algae-illness/historical_habs.htm.

Kansas Department of Health and Environment, 2017, Bluegreen algae (BGA) Blooms: Kansas Department of Health and Environment web page, accessed December 4, 2017, at http://www.kdheks.gov/algae-illness/index.htm.

Kansas State University, 2016, Historical weather: Kansas State University web page, accessed November 3, 2017, at http://mesonet.k-state.edu/weather/historical/.

Kansas Water Office, 2017, Milford Lake Technical Use Summary: Kansas Water Office web page, accessed August 27, 2018, at https://services1.arcgis.com/ q2CglofYX6ACNEeu/arcgis/rest/services/Lakes_All/ FeatureServer/0/74/attachments/345.

King, L.R., 2018a, Milford Lake, Kansas spatial waterquality data, May 26, June 9, July 14, July 21, and September 15, 2016: U.S. Geological Survey data release, https://doi.org/10.5066/F7DJ5DVX.

King, L.R., 2018b, Phytoplankton data for Milford Lake, Kansas, May through November 2016: U.S. Geological Survey data release, https://doi.org/10.5066/F7513XFN.

King, L.R., 2018c, Time-lapse photography of Milford Lake, Kansas, June through November 2016: U.S. Geological Survey data release, https://doi.org/10.5066/F7JH3KCV.
King, L.R., 2018d, Water-quality data from two sites on Milford Lake, Kansas, May 25-26, June 8-10, July 20-21, and September 14-15, 2016: U.S. Geological Survey data release, https://doi.org/10.5066/F78S4P4M.

Neter, J., Kutner, M.H., Nachtsheim, C.J., and Wasserman, W., 1996, Applied linear regression models (3d ed.): The McGraw-Hill Book Companies, Inc., 720 p.

O’Neil, J.M., Davis, T.W., Buford, M.A., and Gobler, C.J., 2012, The rise of harmful cyanobacterial blooms - The potential roles of eutrophication and climate change: Harmful Algae, v. 14, p. 313-334. [Also available at https://doi.org/10.1016/j.hal.2011.10.027.]

Sauer, V.B., and Turnipseed, D.P., 2010, Stage measurement at gaging stations: U.S. Geological Survey Techniques and Methods, book 3, chap. A7, 45 p. [Also available at https://pubs.usgs.gov/tm/tm3-a7/.]

Turnipseed, D.P., and Sauer, V.B., 2010, Discharge measurements at gaging stations: U.S. Geological Survey Techniques and Methods, book 3, chap. A8, 87 p. [Also available at https://pubs.usgs.gov/tm/tm3-a8/.]

U.S. Geological Survey, 2013, National hydrography geodatabase: The National Map viewer, accessed October 16, 2017, at https://viewer.nationalmap.gov/advanced-viewer/.

U.S. Geological Survey, 2018, USGS water data for the Nation: U.S. Geological Survey National Water Information System database, accessed December 2017 at https://doi.org/10.5066/F7P55KJN.

U.S. Geological Survey, variously dated, National field manual for the collection of water-quality data: U.S. Geological Survey Techniques of Water-Resources Investigations, book 9, chaps. A1-A10, accessed October 20, 2016, at https://water.usgs.gov/owq/FieldManual/.

Wagner, R.J., Boulger, R.W., Jr., Oblinger, C.J., and Smith, B.A., 2006, Guidelines and standard procedures for continuous water-quality monitors-Station operation, record computation, and data reporting: U.S. Geological Survey Techniques and Methods, book 1, chap. D3, 51 p. plus 8 attachments, accessed April 10, 2006, at https://pubs.water.usgs.gov/tm1d3.

Wilde, F.D., Sandstrom, M.W., and Skrobialowski, S.C., 2014, Selection of equipment for water sampling (ver. 3.1): U.S. Geological Survey Techniques of Water-Resources Investigations, book 9, chap. A2, accessed December 13, 2017, at https://pubs.water.usgs.gov/twri9A2/.

Yellow Springs Instruments, 2017, EXO user manualAdvanced water quality monitoring platform, Revision G: Yellow Springs Instruments user manual, 154 p., accessed December 21, 2016, at https://www.ysi.com/File\%20 Library/Documents/Manuals/EXO-User-Manual-Web.pdf. 
Publishing support provided by the U.S. Geological Survey Science Publishing Network, Rolla and Sacramento Publishing Service Centers

For more information about this publication, contact: Director, USGS Kansas Water Science Center 1217 Biltmore Drive Lawrence, KS 66049 785-842-9909 https://www.usgs.gov/centers/kswsc 
